\title{
Window-Related Energy Consumption in the US Residential and Commercial Building Stock
}

Joshua Apte and Dariush Arasteh, Lawrence Berkeley National Laboratory LBNL-60146

\section{Abstract \\ We present a simple spreadsheet-based tool for estimating window-related energy consumption in the United States. Using available data on the properties of the installed US window stock, we estimate that windows are responsible for 2.15 quadrillion Btu (Quads) of heating energy consumption and 1.48 Quads of cooling energy consumption annually. We develop estimates of average U-factor and SHGC for current window sales. We estimate that a complete replacement of the installed window stock with these products would result in energy savings of approximately 1.2 quads. We demonstrate that future window technologies offer energy savings potentials of up to 3.9 Quads.}

\section{Introduction}

According to the US Department of Energy, in 2003 space conditioning in residential and commercial buildings was responsible for 9.19 quadrillion Btu (Quads) of site energy consumption, and 12.03 Quads of primary (source) consumption (US DOE Office of Energy Efficiency and Renewable Energy 2005). Although windows are generally understood to be an important driver of space conditioning energy consumption, few studies have directly investigated the energy impacts of windows at the national level. In this study, we introduce a simple spreadsheet-based tool for estimating the national energy impacts of windows in residential and commercial buildings. After presenting estimates of current window-related energy consumption in the US building stock, we discuss the energy savings potential of various technology scenarios.

\section{Methods and Results}

This section is divided into two sub-sections. In the first section, we describe the techniques and assumptions involved in estimating the window-related energy consumption of the US building stock. In the second section, we describe the process we used to estimate the energy-savings potential of various window technologies.

\section{Window-Related Energy Consumption of Building Stock General Approach}

In order to estimate the energy consumption attributable to the US window stock, we used a combination of top-down and bottom-up approaches. First, we compiled a set of estimates of total space conditioning energy consumption in the US building stock, broken down by sector (residential, commercial) and conditioning mode (heating, cooling). Second, for each of these four aggregated end use categories, we combined building energy simulations with market and survey data to estimate the fraction of total energy consumption attributable to windows. We then estimated the window-related space conditioning energy consumption for each end use category by multiplying total space conditioning energy consumption by the window-related fraction of that 
consumption. Finally, we determined a total national estimate by summing across the four end use categories. This approach is formalized below in Equation 1.

\section{Equation 1}

$$
\mathrm{TWE}^{\text {Stock }}=\sum_{\text {S.E }}\left(\text { THE }_{\mathbf{S}, \mathrm{E}}^{\text {Stock }} \times \mathrm{AWF}_{\mathbf{S}, \mathrm{E}}^{\text {Stock }}\right)
$$

where:

TWE ("Total Window Energy") represents the total-window related primary energy consumption of the US building stock.

THE ("Total HVAC Energy") represents the total primary HVAC energy consumption for a given end use in a given sector in the US building stock.

$\boldsymbol{S}$ represents a given sector of the US building stock (Residential or Commercial).

$\boldsymbol{E}$ represents a given end use for space conditioning energy (heating or cooling).

AWF ("Aggregate Window Fraction") represents the window-related fraction of space conditioning energy consumption (heating, cooling) for a given stock segment (residential, commercial).

\section{National Energy Consumption Estimates}

We used estimates of building space conditioning energy consumption published in the 2005 DOE Buildings Energy Databook as the starting point for our analysis, as presented in Table 1. In the following sections, we estimate the fraction of this energy consumption attributable to the installed window stock in residential and commercial buildings. We then estimate how this fraction would change under a variety of window technology scenarios.

Table 1 - Space Conditioning Energy Consumption in US Buildings

\begin{tabular}{|c|c|c|}
\hline \multirow{2}{*}{ End Use } & \multicolumn{2}{|c|}{$\begin{array}{c}\text { Annual HVAC Energy Consumption } \\
\text { Quadrillion Primary BTU (quads) }\end{array}$} \\
\cline { 2 - 3 } & Residential Buildings & Commercial Buildings \\
\hline Heating & 6.90 & 2.45 \\
\hline Cooling & 2.41 & 1.90 \\
\hline Total & 9.31 & 4.35 \\
\hline
\end{tabular}

\section{Window Fraction of Total Energy Consumption}

\section{Background}

Although the effects of windows on energy consumption are well understood at the building level, few studies have attempted a detailed characterization of the national energy impacts of windows. This limitation can be explained by several factors. First, the energy impacts of windows, even at the building level, are difficult to quantify without extensive monitoring and instrumentation. Computer energy simulations therefore offer a far more practical approach; however, the US building stock is highly heterogeneous, meaning dozens if not hundreds of models are required. Moreover, the composition and

\footnotetext{
${ }^{1}$ The term "Quad” is shorthand for 1 quadrillion $\left(10^{15}\right)$ Btu $=1.056$ EJ. "Primary” energy consumption includes a site-to-source conversion factor of 3.22 for electricity to account for losses in transmission, distribution, and generation. All energy consumption is reported in primary terms unless otherwise noted.
} 
properties of the US building stock are poorly characterized with respect to shell integrity and energy efficiency. Detailed descriptions of the installed window stock are nonexistent. The most detailed datasets tend to be limited to a particular geographical region, while those with a national scope often leave key questions unanswered.

In order to estimate the fraction of building space conditioning energy consumption attributable to windows, we conducted a reanalysis of two simulation studies of building HVAC loads originally conducted by Joe Huang and others at Lawrence Berkeley National Laboratory (Huang and Franconi 1999; Huang et al. 1999). These studies relied on an extensive set of DOE-2 models ("prototypical buildings" or "prototypes") designed to capture the diversity of the US residential and commercial building stock. Using parametric simulations, the authors determined the relative contribution of internal heat gains and building envelope components to total space conditioning loads for each prototypical building. By weighting these building-level estimates with stock size data derived from the EIA Residential- and Commercial Building Energy Consumption Surveys (RECS, CBECS), the authors then developed aggregate estimates of total "component loads" for the US building stock.

\section{General Procedure}

We used prototype-level simulation results ${ }^{2}$ published in Huang et al. (1999) and Huang and Franconi (1999) as a starting point for our analysis. These results estimate space conditioning loads attributable to each of a set of internal and envelope components for 80 prototypical residential buildings and 120 prototypical commercial buildings. We term these loads "component loads", and a list of the building component loads simulated in this study can be found in Table 10. We entered these loads into separate spreadsheets for residential and commercial buildings, with separate tables for heating loads and cooling loads. In order to estimate the percentage of space conditioning energy consumption attributable to windows for each of these end use categories, we used a six step process. This process is briefly outlined below (see Figure 1 for a graphical representation) and explained in greater detail in the Residential Buildings and Commercial Buildings subsections.

- First, we categorized the component loads derived by Huang et al. into those that were at least partly attributable to windows (infiltration, window conduction, and window solar gain), and those that were not. For simplicity, we collapsed the loads unrelated to windows into a "non-window" category.

- Second, we used the most recent RECS and CBECS surveys to generate estimates of the size of the US building stock corresponding to each of Huang et al.'s prototypical buildings. We used these size estimates to determine the windowrelated and total loads at the national level that correspond with each of the 320 prototypical buildings simulated by Huang et al.

- Third, we used prototypical building-specific "efficiency factors" derived by Huang et al. to estimate the primary (source) energy consumption necessary to meet space conditioning loads.

\footnotetext{
${ }^{2}$ A list of all prototype buildings can be found in Table 9.
} 
- Fourth, we used information from proprietary market research to generate up-todate estimates of window energy efficiency that reflect the properties of today's window stock. As the assumed window properties of the prototype buildings used in the Huang studies differed from these values, we applied a set of correction factors to the window-related component loads.

- Fifth, we aggregated window and total loads across all building types to develop a set of aggregate space conditioning load estimates for the entire commercial and residential building stocks.

- Finally, we used these aggregated estimates to estimate the window-related fraction of building space conditioning energy consumption in residential and commercial buildings. This value was calculated by dividing the aggregate window-related load by the aggregate total load.

\section{Residential Buildings - Methods}

In this section, we provide additional detail on the methods used to estimate the fraction of residential space conditioning energy consumption attributable to windows. Figure 1 and Figure 2 show two different ways of looking at our procedure. Figure 1 breaks the process used into a linear, step-by-step form. However, the actual process used lends itself to being visualized on two axes (Figure 2). One axis involves estimating the window-related properties of individual segments of the residential building stock, while the other axis aggregates these properties across the entire building stock to develop a national-level estimate.

We chose to limit our analysis of the residential building stock to single-family residences, as significant details on window properties were unavailable for larger residential buildings. We therefore assume that residential window performance is wellapproximated by single-family homes. As the 80 prototypical single-family homes in Huang et al.'s analysis correspond to buildings responsible for $74 \%$ of all residential energy consumption (EIA 2001), we believe this is a reasonable assumption.

The specific number of prototypical buildings (80) stems from Huang et al.'s study design, which divided the US housing stock both spatially (into 20 "climate zones”) and temporally, with 4 construction "vintages" per climate zone. As can be seen in Appendix A, Huang et al.'s climate zones reflect not only climatic variation (in the guise of heating degree day and cooling degree day bands), but also political boundaries in the form of the US Census Divisions. In each climate zone, regionally specific construction patterns are represented by one prototypical building for each of four "vintages" or eras: Pre-1950s, 1950 - 1979, $1980-1989$, and post-1989 ${ }^{3}$. Each of these 80 buildings were simulated with typical weather data (Typical Meteorological Year (TMY) format) for a representative city for each climate zone. Thus, a prototypical home might represent a pre-1950s Boston home, or a 1980s vintage Los Angeles home. For each prototypical

3 Within a given region, the principal differences between different "vintages" include floor area, number of stories, window area, and level of insulation. Detailed descriptions of the properties of these prototypical buildings can be found in cited references(Huang and Franconi 1999; Huang, Hanford et al. 1999). 
building, the contribution of the following components to total HVAC load was estimated:

\begin{tabular}{|c|c|c|}
\hline Roof & Wall & Window Solar Gain $^{*}$ \\
\hline Ground & Equipment & Window Conduction $^{*}$ \\
\hline People & & Infiltration $^{*}$ \\
\hline
\end{tabular}

As a starting point for our analysis, we transcribed Huang et al.'s estimated component loads into a spreadsheet. In their publicly-available format, these loads were presented as population aggregate loads; that is, they represent the sum of a given component load for all US buildings of a particular type. In order to determine building-level loads, we transcribed Huang's building population estimates, which were derived from the 1993 RECS survey. For simplicity, we grouped all non-window related loads into a single category. We assumed that $15 \%$ of total infiltration loads are window related (ASHRAE 2005). This corresponds to step 1 of the general process outlined in Figure 1.

Next, we used data from the 2001 RECS Survey to update Huang's estimates of the national building populations corresponding to each of the 80 prototypical single-family buildings. For our analysis, we used the RECS "microdata", which provides detailed survey responses for each of the 3,000 sampled single-family residences. These data include information on home construction date and local climate (heating degree days and cooling degree days) as well as "sample weight," an estimate of the total number of US homes with comparable properties to the survey home. Using these data, we developed estimates of the number of homes represented by each of the 80 prototypical single-family residences. We then linearly scaled Huang's component loads to reflect changes in building population between 1993 and 2003. For example, if the estimated population corresponding to a particular building decreased by $20 \%$ over this time period, then we estimated that aggregate loads were $20 \%$ smaller as large as well. This process corresponds to step 2 of the general process outlined in Figure 1.

Huang's building prototypes assume that the residential window stock is largely comprised of double-pane windows with wood or aluminum frames (Ritschard et al. 1992). As window properties were originally reported by Huang et al. in the form of center-of-glass U-factor and shading coefficient, we converted these estimates to wholewindow U-factor and SHGC using a procedure developed by Finlayson et al. (Finlayson et al. 1993). In order to develop an up-to-date estimate of today's window stock properties, which have benefited from significant penetration of low-e products, we performed the following procedure. Since windows are replaced on average every 40 years (Ducker Research Company 2004), we estimate that roughly 20\% of the US window stock was replaced between 1993 and 2001. Based on this observation, we developed an estimate of the typical properties of windows sold over the time period (Table 2). For each prototypical building, we estimated today's average U and SHGC with the following weighting: Pre-1993 whole window properties, 80\%; 1993-2001 Sales properties, $20 \%$. Based on this, we estimate the average U-factor of the residential building stock to be $0.75 \mathrm{Btu} /\left(\mathrm{hr}^{\left.-\mathrm{ft}^{2}-{ }^{\circ} \mathrm{F}\right)}\right.$ and the average SHGC to be 0.68 . For each 
prototypical building, we developed window load scaling factors that encapsulate our updated estimates of window $U$ and SHGC (Equation 2 and Equation 3). This process corresponds with step 4 in Figure 1. As described below, we use these factors to linearly scale Huang et al.'s estimated window loads.

Equation 2 - Scaling Factor for Window Solar Heat Gain

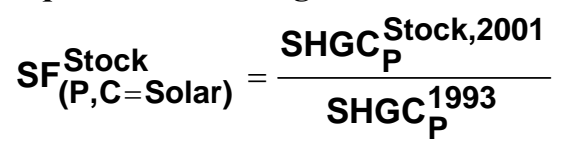

Equation 3 - Scaling Factor for Window Conduction

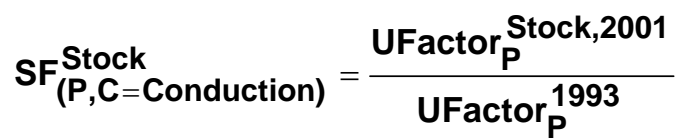

where:

SF ("Scaling Factor") represents the load scaling factor for a particular residential prototypical building and window-related component load type.

$\boldsymbol{C}$ is a given window-related component load type (infiltration, solar gain or conduction); $\boldsymbol{P}$ is a given prototypical residential building.

SHGC is Solar Heat gain coefficient assumed by Huang et al.. or the current authors. As described in the text, we used whole-window U and SHGC determined using the procedure developed by Finlayson et al.

$\boldsymbol{U}$-factor is U-factor in Btu/(hr- $\left.\mathrm{ft}^{2}{ }^{\circ}{ }^{\circ} \mathrm{F}\right)$ assumed by Huang et al. or the current authors. As described in the text, we used whole-window $\mathrm{U}$ and SHGC determined using the procedure developed by Finlayson et al.

Table 2 - Assumed Properties of Residential Window Sales 1993 - 2001

\begin{tabular}{|c|c|c|c|}
\hline Type of Window & $\begin{array}{c}\text { Percentage of Sales, } \\
\mathbf{1 9 9 3 - \mathbf { 2 0 0 1 }}\end{array}$ & $\begin{array}{c}\text { U-factor } \\
\left.\text { Btu/(hr-ft }^{\mathbf{2}}{ }^{\circ} \mathbf{F}\right)\end{array}$ & SHGC \\
\hline Single Pane & $8 \%$ & 1.16 & 0.76 \\
\hline Double Pane & $45 \%$ & 0.59 & 0.56 \\
\hline Double Pane Low-e & $45 \%$ & 0.35 & 0.35 \\
\hline Triple Pane & $2 \%$ & 0.20 & 0.40 \\
\hline Average Properties & - & $\mathbf{0 . 5 2}$ & $\mathbf{0 . 4 8}$ \\
\hline
\end{tabular}

Sources: Window Sales Data: Ducker Research Company, 2004. Typical window properties: Carmody et al, 2000.

At this point in our analysis, we have updated Huang's estimates of window-related loads in all 80 residential buildings to reflect changes in housing stock populations and window energy efficiency. In order to illustrate the process thus far, Figure 2 gives a template view of this process for three fictitious prototypical buildings. This process is formalized in Equation 4 and Equation 5. Our updated estimated loads for all residential buildings can be found in Appendix D.

Equation 4 - Updated Window-Related Loads for Subset of Residential Building Stock

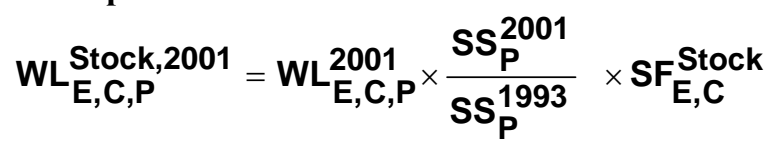


Equation 5 - Updated Total Building Load for Subset of Residential Building Stock

$\mathrm{TL}_{\mathrm{E}, \mathrm{P}}^{2001}=\left(\mathrm{TL}^{1993}+\sum_{\mathrm{C}} \mathrm{WL}_{\mathrm{E}, \mathrm{C}, \mathrm{P}}^{2001}-\sum_{\mathrm{C}} \mathrm{WL}_{\mathrm{E}, \mathrm{C}, \mathrm{P}}^{1993}\right) \times \frac{\mathrm{SS}_{\mathrm{P}}^{2001}}{\mathrm{SS}_{\mathrm{P}}^{1993}}$

where:

$\boldsymbol{E}$ is a given end use (Heat, Cool).

$\boldsymbol{C}$ is a given window-related component load type (infiltration, solar gain, or conduction);

$\boldsymbol{P}$ is a given prototypical residential building.

WL ("Window Load") is a window-related load.

SF ("Scaling Factor") represents the load scaling factor for a particular residential prototypical building and window-related component load type.

TL ("Total Load") is the total space conditioning load for a given end use in a given prototypical building.

SS ("Stock Size") is the size of the building stock (in square feet of conditioned floor area) for a given prototypical building for a given year and end use.

The next step in our analysis was to aggregate window related loads to the national level (this corresponds to Step 5 in Figure 1). Since loads were already aggregated to the national level for each prototypical building (Figure 2), it was a trivial step to sum these loads across all 80 prototypical buildings to determine a national total of loads. We performed this separately for total building loads and each of the three window related loads (solar heat gain, conduction, and infiltration). Next, we divided window loads by total loads (formalized in Equation 6) to determine the window fraction of total loads (Step 6 in Figure 1). Finally, we make the assumption that the window fraction of building loads is a good approximation of the window fraction of total energy consumption. We believe that this is a conservative assumption, for two reasons. First, the overall range of efficiencies for home space conditioning systems is relatively small, at least in comparison to commercial buildings. Second, since less energy-efficient windows are likely to be found in homes with less-efficient space conditioning systems, the assumption of equal system efficiency at worst leads to an understatement of the true energy impacts of windows.

\section{Equation 6 - Window Fraction of Total Space Conditioning Consumption for Given End Use AWF $_{\text {(S=Residential,E) }}^{\text {Stock }}=\frac{\sum_{\mathrm{C}, \mathrm{P}} \mathrm{WL}_{\mathrm{E}, \mathrm{C}, \mathrm{P}}^{\text {Stock,2001 }}}{\sum_{\mathrm{C}, \mathrm{P}} \mathrm{TL}_{\mathrm{E}, \mathrm{P}}^{2001}}$}

where:

AWF ("Aggregate Window Fraction") is the aggregate fraction of total space conditioning energy consumption attributable to windows in the US residential building stock, for a given end use. 
$\underline{\text { Residential Buildings - Results }}$

Table 3 - Estimated Window-Related Energy Consumption for 2003 Residential Building Stock

\begin{tabular}{|c|c|c|c|c|c|}
\hline & \multirow{2}{*}{$\begin{array}{c}\text { Total Annual HVAC } \\
\text { Consumption }{ }^{4} \\
\text { Quadrillion Primary BTU (Quads) }\end{array}$} & \multicolumn{2}{|c|}{$\begin{array}{l}\text { Window \% of HVAC } \\
\text { Consumption }\end{array}$} & \multicolumn{2}{|c|}{$\begin{array}{c}\text { Window \% of HVAC } \\
\text { Consumption, No Infiltration }\end{array}$} \\
\hline & & $\%$ of total & Window Quads & $\%$ of Total & Window Quads \\
\hline Residential Heat & 6.90 & $24 \%$ & 1.65 & $19 \%$ & 1.30 \\
\hline Residential Cool & 2.41 & $42 \%$ & 1.02 & $39 \%$ & 0.94 \\
\hline Residential Total & 9.31 & $29 \%$ & 2.67 & $24 \%$ & 2.24 \\
\hline
\end{tabular}

Table 3 presents aggregate estimates of window-related energy consumption for the US residential building stock. The first column, “Total Annual HVAC Consumption,” contains DOE estimates of total (primary) residential space conditioning energy use for 2003 (see above section entitled “National Energy Consumption Estimates”). In the second column, we present our estimate of the total fraction of residential space conditioning energy use attributable to windows. We estimate that windows are responsible for $24 \%$ of residential heating energy use and $42 \%$ of residential cooling energy use, or $29 \%$ of all residential space conditioning energy use. This is equivalent to 1.65 quads of heating energy use and 1.02 quads of cooling energy use, or a total of 2.67 quads of space conditioning energy use (third column). This is equivalent to roughly $2.7 \%$ of total US energy consumption. The final two columns present our estimates excluding window infiltration ${ }^{5}$.

\section{Commercial Buildings - Methods}

Our methods for determining the window fraction of loads in commercial buildings are similar in general form to those used for residential buildings. Due to the diversity of the commercial building stock, we used Huang and Franconi's DOE-2 simulations of the 12 most common building types (see Table 9), which account for $74 \%$ of building floor area and $79 \%$ of energy consumption. We thus assume that the window properties of these 12 building types reflect those of the entire commercial building stock. This corresponds to a set of 120 parametric building simulations by Huang et al., described below.

For each of the twelve commercial building types identified by Huang and Franconi in their component load analysis, at least two prototypical buildings were developed to reflect "old" (Pre-1980) and "new" (Post-1980) construction patterns. These prototypical commercial buildings drew heavily on information available in the 1989 CBECS dataset. Owing to insufficient regional data in this CBECS dataset, a single national prototypical building was developed by Huang and Franconi for each of six of the twelve simulated building types (Appendix B). Each of these DOE-2 prototypical buildings was then simulated with weather data from cities corresponding to the 5 CBECS climate zones

\footnotetext{
${ }^{4}$ As reported in the 2005 Buildings Energy Databook Table 1.2.3 (US DOE Office of Energy Efficiency and Renewable Energy 2005).

${ }^{5}$ Controlling window infiltration is primarily a matter of applying developed technologies to window production and installation. Since the energy savings that improved window products are largely unrelated to infiltration rates, we present total window stock energy consumption both with and without infiltration for comparison purposes.
} 
(Appendix B, Figure 5). For the remaining six building types, prototypical buildings were developed to correspond to broad "North" and "South" geographical regions (Appendix B, Figure 4). Huang and Franconi simulated these prototypical buildings with weather data typifying each of the 5 CBECS climate zones as shown in Appendix B.

This procedure resulted in a set of 120 parametric building simulations. The results of these simulations are publicly available in Huang and Franconi (1999), and are presented as specific loads (MBtu/sq ft floor area) for the following building components:

\begin{tabular}{|c|c|c|}
\hline Roof & Wall & Window Solar Gain $^{*}$ \\
\hline Ground & Electric/Non-Electric Equipment & Window Conduction $^{*}$ \\
\hline People & Outdoor Air & Infiltration $^{*}$ \\
\hline Floor & Lighting \\
\hline \multicolumn{2}{|c}{} \\
\hline
\end{tabular}

As a starting point for our analysis, we transcribed these results into a spreadsheet and categorized simulated component loads into those related to windows, and those not (Table 10). We assumed that $15 \%$ of all infiltration loads were window-related (ASHRAE 2005). As with the residential analysis, we grouped all non-window loads into a single category. This corresponds to Step 1 of the general process outlined in Figure 1.

Next, we used the 1999 CBECS $^{6}$ to estimate floor areas associated with each of the prototypical buildings simulated by Huang and Franconi. Similar to our residential analysis above, we used the CBECS "microdata" dataset, which encompasses approximately 3,700 buildings relevant to our study. Relevant reported information from the study included heated and cooled floor area, window type, age, location and sample weight. We used these data to estimate the heated and cooled floor area corresponding to each of Huang and Franconi's simulated prototypical buildings. This corresponds to Step 2 of the general process outlined in Figure 1.

In our analysis of window-related energy consumption in residential buildings, we assumed that the average efficiency of space conditioning systems across all singlefamily homes was similar. This conservative assumption allowed us to use estimated building loads as a proxy for building energy consumption. However, this is less possible for commercial buildings, where the efficiency of systems exhibits a great range of diversity across building types. Ignoring this diversity would tend to overestimate the energy impacts of windows in relatively more efficient buildings. In order to account for this, Huang and Franconi developed a metric known as "system factor," which estimates the amount of primary energy consumption required by space conditioning equipment to meet a given quantity of space conditioning load. We used building-specific system factors to convert Huang and Franconi's estimated loads into estimated energy consumption. This corresponds to Step 3 of the general process outlined in Figure 1.

\footnotetext{
${ }^{6}$ Although the 2003 CBECS provides more-up-to-date floor area estimates, regionally disaggregated data were unavailable.
} 
The window properties of the prototypical commercial buildings modeled by Huang and Franconi appeared to be anomalously efficient, with an average U-factor of $0.64 \mathrm{Btu} / \mathrm{hr}-$ $\mathrm{ft}^{2}{ }^{\circ} \mathrm{F}$ ) and SHGC of 0.66. Although data on the installed window stock in commercial buildings are exceedingly sparse, information contained in the CBECS survey leads us to believe that roughly half of the installed window stock has double-pane glass, with the remainder single pane (US DOE Energy Information Administration 1999), with windows mostly in aluminum frames. Since a typical U-factor for double-pane window in aluminum frame is around $0.70 \mathrm{Btu} /\left(\mathrm{hr}^{-} \mathrm{ft}^{2}{ }^{\circ}{ }^{\circ} \mathrm{F}\right.$ ) (ASHRAE 2005), we believe that

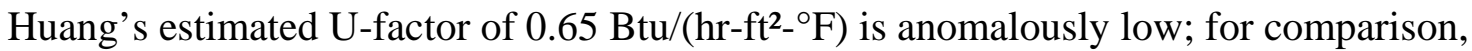
single-pane windows in aluminum frame have a typical U-factor of $\sim 1.2 \mathrm{Btu} /\left(\mathrm{hr}_{-}-\mathrm{ft}^{2}{ }^{\circ} \mathrm{F}\right)$. In the absence of better data, we assumed that all commercial windows in the 1999 building stock have U-factor of $0.75 \mathrm{Btu} /\left(\mathrm{hr}^{\left.-\mathrm{ft}^{2}-{ }^{\circ} \mathrm{F}\right)}\right.$ and SHGC of 0.66 . This may still be a conservative estimate for $\mathrm{U}$-factor given the large installed stock of single-pane glass in commercial buildings.

In order to account for the effects of these altered window properties on overall commercial building loads, we developed a set of scaling factors for each of the prototypical buildings simulated by Huang and Franconi. We assumed that conduction loads scale linearly with respect to U-factor, and solar gains scale linearly with respect to SHGC (Equation 6 and Equation 7). In the absence of more detailed data, we assumed that window infiltration is a constant $15 \%$ of total building infiltration for all window types. Following these assumptions, we created updated estimates for population aggregated window-related loads (Equation 9) for each prototypical building. This was accomplished by multiplying Huang and Franconi's estimated specific component loads for each prototypical building by their estimated efficiency factors, and our estimated window scaling factors and CBECS population sizes. We compensated for the effect of changed window efficiency by increasing or decreasing Huang and Franconi's estimated total building energy consumption by the amount estimated window energy consumption changed as a result of our modifications (Equation 10). Estimated aggregate window loads for the CBECS populations corresponding to all 120 prototypical building types can be found in Appendix E. Finally, we summed all 120 prototype-specific aggregate estimates of both window and total-building energy consumption in order to derive national totals. By dividing window consumption by total energy consumption, we estimated the window-related fraction of commercial building space conditioning energy consumption (Equation 11).

Equation 7 - Scaling factor for Window Solar Heat Gain

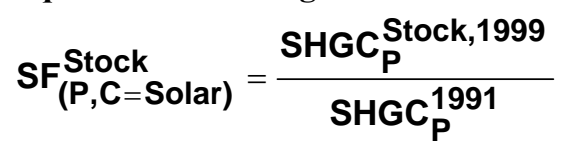

Equation 8 - Scaling Factor for Window Conduction

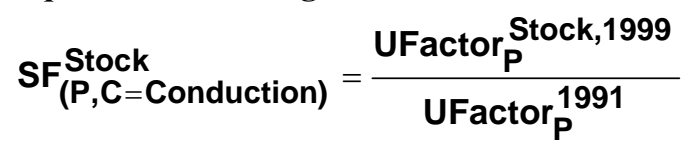


Equation 9 - Updated Window-Related Loads for Subset of Commercial Building Stock

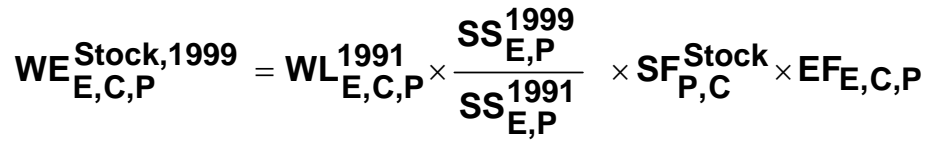

Equation 10 - Updated Total Building Load for Subset of Commercial Building Stock

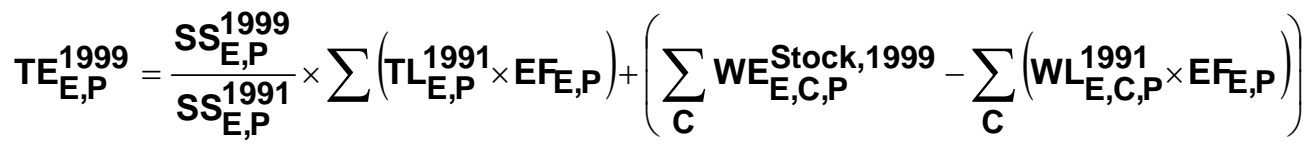

Equation 11 - Window Fraction of Total Space Conditioning Consumption for Given End Use

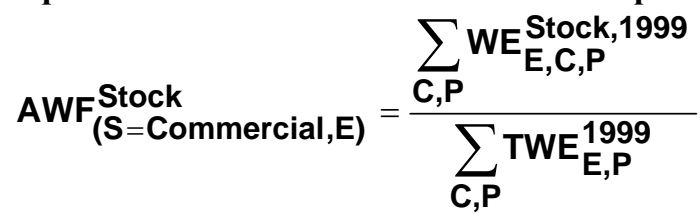

where:

$\boldsymbol{E}$ is a given end use (Heat, Cool).

$\boldsymbol{C}$ is a given window-related component load type (infiltration, solar gain, or conduction).

$\boldsymbol{P}$ is a given prototypical commercial building.

WL ("Window Load") is a window-related load.

$\boldsymbol{E F}$ ("Efficiency Factor") is the ratio of primary energy consumption to HVAC loads for a given end use and prototype.

WE ("Window Energy") is window-related energy consumption.

SHGC is Solar Heat gain coefficient assumed by Huang and Franconi or the authors.

$\boldsymbol{U}$-factor is U-factor assumed by Huang and Franconi or the authors.

SF ("Scaling Factor") represents the load scaling factor for a particular commercial prototypical building and window-related component load type.

SS ("Stock Size") is the size of the building stock (in square feet of conditioned floor area) for a given prototypical building for a given year and end use.

TL ("Total Load") is the total space conditioning load for a given end use in a given prototypical building.

$\mathbf{T E}$ ("Total Energy") is total space conditioning energy consumption for a given end use in a given prototypical building.

AWF ("Aggregate Window Fraction") is the aggregate fraction of total space conditioning energy consumption attributable to windows in the US commercial building stock, for a given end use.

\section{Commercial Buildings - Results}

Table 4 - Estimated Window-Related Energy Consumption in Commercial Buildings

\begin{tabular}{|c|c|c|c|c|c|}
\hline & \multirow{2}{*}{$\begin{array}{c}\text { Total Annual HVAC } \\
\text { Consumption }{ }^{7} \\
\text { Quadrillion Primary BTU (Quads) } \\
\end{array}$} & \multicolumn{2}{|c|}{$\begin{array}{l}\text { Window \% of HVAC } \\
\text { Consumption }\end{array}$} & \multicolumn{2}{|c|}{$\begin{array}{c}\text { Window \% of HVAC } \\
\text { Consumption, No Infiltration }\end{array}$} \\
\hline & & $\%$ of total & Window Quads & $\%$ of Total & Window Quads \\
\hline Commercial Heat & 2.45 & $39 \%$ & 0.96 & $35 \%$ & 0.85 \\
\hline Commercial Cool & 1.90 & $28 \%$ & 0.52 & $28 \%$ & 0.54 \\
\hline Commercial Total & 4.35 & $34 \%$ & 1.48 & $32 \%$ & 1.39 \\
\hline
\end{tabular}

${ }^{7}$ As reported in the 2005 Buildings Energy Databook Table 1.3.3 (US DOE Office of Energy Efficiency and Renewable Energy 2005). 
Table 4 presents aggregate estimates of window-related energy consumption for the US commercial building stock. The first column, "Total Annual HVAC Consumption," contains DOE estimates of total (primary) commercial space conditioning energy use for 2003 (see above section entitled “National Energy Consumption Estimates”). In the second column, we present our estimate of the total fraction of commercial space conditioning energy use attributable to windows. We estimate that windows are responsible for $39 \%$ of commercial heating energy use and $28 \%$ of commercial cooling energy use, or $34 \%$ of all commercial space conditioning energy use. This is equivalent to 0.96 quads of heating energy use and 0.52 quads of cooling energy use, or a total of 1.48 quads of space conditioning energy use (third column). This is equivalent to roughly $1.5 \%$ of total US energy consumption. The final two columns present our estimates excluding window infiltration.

\section{Future Scenarios - Technology Potential Scenarios}

In this section, we present estimates of the energy savings potential of a set of potential future window technology scenarios. For each window technology scenario, we present assumptions of typical technical performance characteristics (U-factor and SHGC) and estimates of the overnight stock turnover energy savings potential; that is, the energy savings that would result if today's entire window stock were replaced overnight with that window technology. Although this instant change is unrealistic, such estimates provide useful insight into the relative merits of different window technologies.

\section{General Approach}

The methods used in this section draw heavily on the techniques used to estimate the energy consumption of the existing U.S. window stock, as described in previous sections. In order to estimate the energy savings potential of a given window technology, we first estimated the total window-related energy consumption that would result in the US building stock if all windows were replaced with that window technology (Equation 12). In order to do this, we developed a set of scenarios that characterizes the properties (Ufactor and SHGC) of a range of existing and future window technologies. For each scenario, we used our models of the existing residential and commercial building stock (see earlier sections) to estimate what the window-related fraction of space conditioning energy consumption would be if all windows in the existing building stock were replaced with that technology. We then estimated the energy savings potential of a given technology scenario using Equation 13. In the following sub-sections, we present a more detailed explanation of the methods and assumptions involved in our energy savings estimates for the U.S. residential and commercial building stock. We then present our results.

Equation 12 - Equation to estimate total window-related energy consumption under a given technology scenario

TWE $^{\text {Scenario }}=\sum_{\text {S,E }}\left(\right.$ THE $_{\text {S,E }}^{\text {Stock }} \times$ AWF $\left._{S, E}^{\text {Scenario }}\right)$ 


\section{Equation 13 - Estimation of Energy Savings Potential of a Given Window Technology Scenario TWS $^{\text {Scenario }}=$ TWE ${ }^{\text {Stock }}-$ TWE $^{\text {Scenario }}$}

Where:

TWS ${ }^{\text {Senario }}$ ("total window savings") represents the energy savings potential of a given window technology scenario if today's current window stock were replaced with a certain window technology.

$\mathbf{T W E}^{\text {Scenario }}$ ("total window energy") represents the total-window related primary energy consumption of the US building stock under a given window technology scenario, as estimated in this section.

TWE ${ }^{\text {Stock }}$ ("total window energy") represents the total-window related primary energy consumption of today's US building stock, as estimated in the previous section.

THE ("total HVAC energy") represents the total primary HVAC energy consumption for a given end use in a given sector in the US building stock.

$\boldsymbol{S}$ represents a given sector of the US building stock (Residential or Commercial)

$\mathbf{E}$ represents a given end use for space conditioning energy (heating or cooling),

and

AWF ("Aggregate Window Fraction") is the aggregate fraction of total space conditioning energy consumption attributable to windows in the US residential building stock, for a given end use.

$\underline{\text { Residential Buildings - Methods and Assumptions }}$

We estimated energy savings potential for seven residential window technology scenarios, described below. Assumed U-factors and SHGCs are presented in Table 5.

Table 5 - Residential Window Technology Scenarios Considered

\begin{tabular}{|c|c|c|}
\hline Window Type & $\begin{array}{c}\text { U-factor } \\
\text { Btu / }\left(\mathbf{h r}^{-} \mathrm{ft}^{2} \mathrm{-}^{-} \mathbf{F}\right)\end{array}$ & $\begin{array}{c}\text { Solar Heat Gain } \\
\text { Coefficient (SHGC) }\end{array}$ \\
\hline Sales (Business as usual) & 0.46 & 0.42 \\
\hline Energy Star (Low-e) & $\begin{array}{l}\text { North: } 0.35 \\
\text { North/South Central: } 0.4 \\
\text { South : } 0.65\end{array}$ & 0.4 \\
\hline Dynamic Low-e & 0.35 & $0.15 / 0.40$ \\
\hline Triple Pane Low-e & 0.18 & 0.40 \\
\hline Mixed Triple, Dynamic & $\begin{array}{c}\text { Northern U.S.: See T } \\
\text { Central/Southern U.S.: Se } \\
\end{array}$ & $\begin{array}{l}\text { e Low-e properties } \\
\text { ynamic Low-e properties }\end{array}$ \\
\hline High-R & 0.10 & 0.40 \\
\hline High-R Dynamic & 0.10 & $0.15 / 0.50$ \\
\hline
\end{tabular}

The scenario Sales reflects the average properties of residential windows sold today (Ducker Research Company 2004). This could be considered a business-as-usual scenario; if the market shares of today's mix of window technologies stayed constant, we would expect the window stock to eventually become quite similar to sales. Note, however, that savings estimates below present energy savings in terms of an overnight replacement of today's window stock. A detailed description of assumptions is presented in Appendix C.

The Energy Star scenario reflects typical properties for products meeting the DOE Energy Star window specification, which often have one or more low-e coatings. These high-performance products are rapidly becoming the standard residential window, with 
over 50\% market penetration (Ducker Research Company 2004). A detailed description of assumptions is presented in Appendix C.

The Dynamic Low-e scenario reflects the properties of a hypothetical window product that dynamically changes its solar gain properties to admit or reject solar gains to minimize window-related energy consumption. For modeling purposes, we assume that dynamic window products maintain a low solar heat gain whenever cooling is required and high solar heat gain whenever heating is required. This scenario reflects a window system with a U-factor similar to today's double-glazed low-e windows, but with dynamic solar heat gain control. Such a product is now available commercially from Sage Electrochromics, Inc (Sage Electrochromics 2006).

The Triple Pane Low-e scenario is representative of high-end triple glazed windows available today.

The Mixed Triple, Dynamic scenario considers a regionally optimized deployment of windows from the Dynamic Low-e and Triple Pane Low-e scenarios. We assume that triple pane low-e windows are used in the northern US (where heating dominates space conditioning energy consumption, so low U-factors are of particular benefit), and dynamic low-e windows in the remainder of the country. A detailed description of assumptions is presented in Appendix C.

The High-R scenario considers a highly insulating (U-factor $=0.10 \mathrm{Btu} /\left(\mathrm{hr}_{-} \mathrm{ft}^{2}{ }^{\circ} \mathrm{F}\right)$ ) window with fixed solar heat gain properties. Off-the-shelf technologies currently do not exist for such products; however, these windows are under active R\&D at Lawrence Berkeley National Laboratory and elsewhere.

The Dynamic High-R scenario considers a potential outer bound of window energy performance: highly insulting windows with dynamically controllable solar heat gain across a very large range.

For each of the above-described scenarios, we estimated the potential energy savings from overnight stock turnover as follows. First, for each prototypical building, we developed a set of window energy consumption scaling factors for conduction and solar loads (Equation 14 and Equation 15). For solar loads, this scaling factor reflects the ratio of assumed SHGC in a given window technology scenario to our corrected wholewindow estimates of SHGC used by Huang et al. (see residential window stock section). Similarly, for conduction loads, this scaling factor reflects the ratio of scenario U-factor to our corrected estimate of whole-window U-factor.

Second, we estimated window related-energy consumption under each scenario for each subset of the residential building stock corresponding to a single prototypical building (Equation 16) ${ }^{8}$. Third, we aggregated energy consumption across each residential prototypical building category in order to develop an estimate of total window-related

\footnotetext{
${ }^{8}$ As in the procedure used in Equation 4, we assume that system efficiencies are relatively constant across the residential stock in order to use HVAC loads as a proxy for HVAC energy consumption.
} 
energy consumption for each scenario. By dividing this by the estimated residential building stock energy consumption developed in Equation 5, we estimated the window fraction of HVAC energy consumption for each scenario (Equation 17). These steps correspond to the procedure used earlier in estimating residential window stock energy consumption (Equation 4 and Equation 6). Finally, we used Equation 12 and Equation 13 to calculate the energy savings potential of each technology scenario.
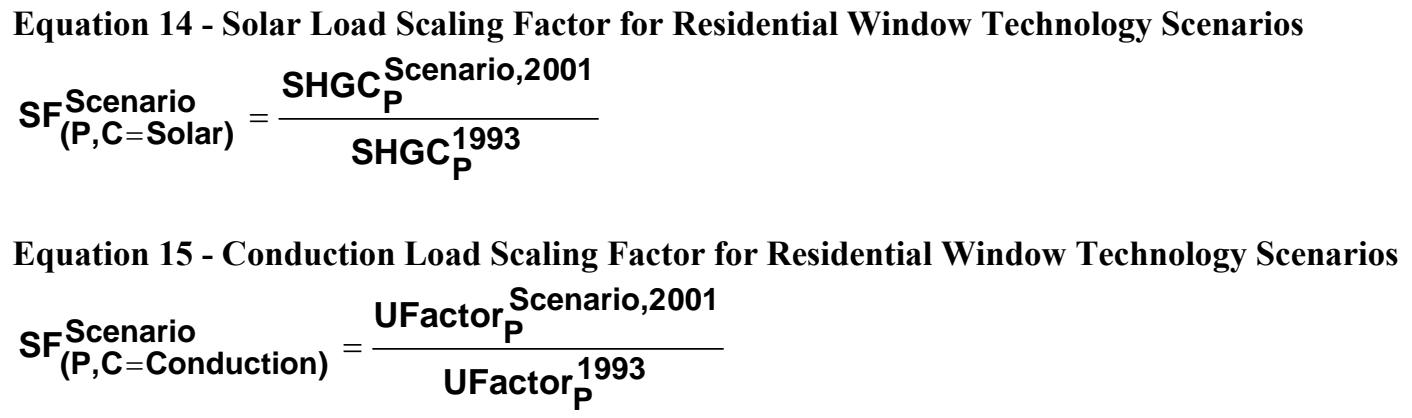

Equation 16 - Scenario Total Building Load for Subset of Residential Building Stock

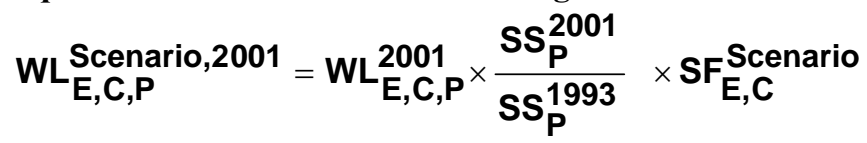

Equation 17 - Window Fraction of Residential HVAC Energy Consumption for Window Technology Scenarios

$$
\operatorname{AWF}_{(S=\text { Residential }, E)}^{\text {Scenario }}=\frac{\sum_{C, P} W L_{E, C, P}^{\text {Scenario,2001 }}}{\sum_{C, P} T_{E, P}^{2001}}
$$

Where:

$\boldsymbol{E}$ is a given end use (Heat, Cool).

$\boldsymbol{C}$ is a given window-related component load type (infiltration, solar gain, or conduction).

$\boldsymbol{P}$ is a given prototypical commercial building.

WL ("Window Load") is a window-related load.

SHGC is Solar Heat gain coefficient assumed by Huang et al. or the authors.

$\boldsymbol{U}$-factor is U-factor assumed by Huang et al. or the authors.

SF ("Scaling Factor") represents the load scaling factor for a particular commercial prototypical building and window-related component load type.

SS ("Stock Size") is the size of the building stock (in square feet of conditioned floor area) for a given prototypical building for a given year and end use.

AWF ("Aggregate Window Fraction") is the aggregate fraction of total space conditioning energy consumption attributable to windows in the US commercial building stock, for a given end use.

\section{$\underline{\text { Residential Buildings - Results }}$}

Estimates of savings potential for residential window technology scenarios are presented in Table 6. 
Table 6 - Energy Savings Potential of Residential Window Technology Scenarios

\begin{tabular}{|l|c|c|c|}
\hline \multicolumn{1}{|c|}{ Scenario } & \multicolumn{3}{c|}{ Energy Savings over Current Stock } \\
& Heat, quads & Cool, quads & Total, quads \\
\hline Sales (Business as usual) & 0.49 & 0.37 & 0.86 \\
\hline Energy Star (Low-e) & 0.69 & 0.43 & 1.12 \\
\hline Dynamic Low-e & 0.74 & 0.75 & 1.49 \\
\hline Triple Pane Low-e & 1.20 & 0.44 & 1.64 \\
\hline Mixed Triple, Dynamic & 1.22 & 0.55 & 1.77 \\
\hline High-R Superwindow & 1.41 & 0.44 & 1.85 \\
\hline High-R Dynamic & 1.50 & 0.75 & 2.25 \\
\hline
\end{tabular}

We offer the following observations on energy savings potentials in the residential sector:

- The “ENERGY STAR” scenario offers relatively modest energy savings beyond the business-as usual case ( 0.3 quads). This is due to the large fraction of ENERGY STAR windows which make up current sales.

- $\quad$ Triple pane low-e windows, today's highest-performers, offer 0.8 quads of savings beyond the business-as-usual case, focused mainly in heating dominated climates.

- Next-generation "High-R Superwindows" offer energy savings significantly beyond sales (1.0 quads), with savings again mostly in heating applications.

- $\quad$ Even deeper energy savings can be achieved by coupling dynamic solar heat gain control with highly insulating windows. High-R Dynamic windows offer $\sim 1.4$ quads of energy savings beyond sales. Here, the entire U.S. window stock would result in zero net heating energy consumption on a national basis, while cooling energy consumption would be reduced by $80 \%$ from current values.

Commercial Buildings - Methods and Assumptions

We estimated energy savings potential for five commercial window technology scenarios, described below. Assumed U-factors and SHGCs are presented in Table 7.

Table 7 - Commercial Window Technology Scenarios Considered

\begin{tabular}{|c|c|c|}
\hline Window Type & $\begin{array}{c}\text { U-factor } \\
\left.\text { Btu /(hr- }-\mathrm{ft}^{2}{ }^{\circ} \mathrm{F}\right)\end{array}$ & SHGC \\
\hline Sales (Business as usual) & 0.62 & 0.48 \\
\hline Low-e & 0.40 & 0.29 \\
\hline Dynamic Low-e & 0.40 & $0.10 / 0.40$ \\
\hline Triple Pane Low-e & 0.20 & 0.25 \\
\hline High-R Dynamic & 0.15 & $0.05 / 0.50$ \\
\hline
\end{tabular}

The Sales (business-as-usual) scenario reflects the average properties of commercial windows sold today (Ducker Research Company 2004). A detailed description of assumptions is presented in Appendix C. 
The Low-e scenario reflects typical properties for low-e double paned windows in commercial buildings. In contrast to the residential sector, low-e windows still have relatively low market penetration (30\%) (Ducker Research Company 2004).

The Dynamic Low-e scenario reflects the properties of a hypothetical window product that dynamically changes its solar gain properties to admit or reject solar gains to minimize window-related energy consumption. This scenario reflects a window system with a U-factor similar to today's double-glazed low-e windows, but with dynamic solar heat gain control. For modeling purposes, we assume that dynamic window products maintain a low solar heat gain whenever cooling is required and high solar heat gain whenever heating is required. Note that the control strategy presented achieves optimal results in reducing building HVAC energy consumption, but may produce sub-optimal whole building energy savings due to interactions with lighting.

The Triple Pane Low-e scenario is representative of high-end triple glazed windows available today.

The High-R Dynamic scenario considers very highly insulating windows with dynamically controllable solar heat gain properties switching over a broad range of SHGCs.

Energy savings potentials for these scenarios were estimated much the same as those for the residential window scenarios (Equation 12 - Equation 17). First, for each prototypical building, we developed a set of window energy consumption scaling factors for conduction and solar loads (Equation 18 and Equation 19). For solar loads, this scaling factor reflects the ratio of assumed SHGC in a given window technology scenario to our corrected whole-window estimates of SHGC used by Huang and Franconi (SHGC = 0.66 , see commercial window stock section). Similarly, for conduction loads, this scaling factor reflects the ratio of scenario U-factor to our corrected estimate of whole-window U-factor $\left(0.75 \mathrm{Btu} /\left(\mathrm{hr}^{-\mathrm{ft}^{2}-}{ }^{\circ} \mathrm{F}\right)\right)$.

Second, we estimated window related-energy consumption under each scenario for each subset of the commercial building stock corresponding to a single prototypical building (Equation 20). Third, we aggregated energy consumption across each residential prototypical building category in order to develop an estimate of total window-related energy consumption for each scenario. By dividing this by the estimated commercial building stock energy consumption developed in Equation 10, we estimated the window fraction of HVAC energy consumption for each scenario (Equation 21). These steps correspond to the procedure used earlier in estimating commercial window stock energy consumption (Equation 9 and Equation 11). Finally, we used Equation 12 and Equation 13 to calculate the energy savings potential of each technology scenario.

Equation 18 - Solar Load Scaling Factor for Commercial Window Technology Scenarios

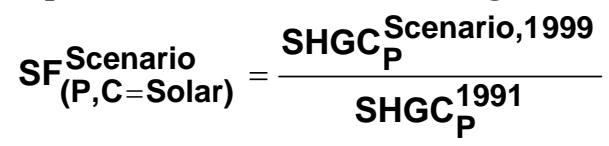


Equation 19 - Conduction Load Scaling Factor for Commercial Window Technology Scenarios $\mathrm{SF}_{(\mathrm{P}, \mathrm{C}=\text { Conduction })}^{\text {Scenario }}=\frac{\text { UFactor }_{\mathbf{P}}^{\text {Scenario,1999 }}}{\text { UFactor }_{\mathbf{P}}^{1991}}$

Equation 20 - Scenario Total Building Consumption for Subset of Commercial Building Stock $W_{E, C, P}^{\text {Scenario,1999 }}=W_{E, C, P}^{1991} \times \frac{S S_{E, P}^{1999}}{S S_{E, P}^{1991}} \times S F_{P, C}^{\text {Scenario }} \times E F_{E, P}$

Equation 21 - Window Fraction of Commercial HVAC Energy Consumption for Window Technology Scenarios

$$
\left.\operatorname{AWF}_{(S=\text { Commercial }, E)}^{\text {Scenario }}\right)=\frac{\sum_{C, P} W_{E, C, P}^{\text {Scenario,1999 }}}{\sum_{C, P} \text { TC }_{E, P}^{1999}}
$$

$\boldsymbol{E}$ is a given end use (Heat, Cool).

$\boldsymbol{C}$ is a given window-related component load type (infiltration, solar gain, or conduction).

$\boldsymbol{P}$ is a given prototypical residential building.

WL ("Window Load") is a window-related load.

$\boldsymbol{E F}$ ("Efficiency Factor") is the ratio of primary energy consumption to HVAC loads for a given end use and prototype.

WE ("Window Energy") is window-related energy consumption.

SHGC is Solar Heat gain coefficient assumed by Huang and Franconi or the authors.

$\boldsymbol{U}$-factor is U-factor assumed by Huang and Franconi or the authors.

SF ("Scaling Factor") represents the load scaling factor for a particular residential prototypical building and window-related component load type.

SS ("Stock Size”) is the size of the building stock (in square feet of conditioned floor area) for a given prototypical building for a given year and end use.

AWF ("Aggregate Window Fraction") is the aggregate fraction of total space conditioning energy consumption attributable to windows in the US residential building stock.

\section{Commercial Buildings - Results}

Estimates of savings potential for commercial window technology scenarios are presented in Table 8.

Table 8 - Estimated Energy Savings from Commercial Window Technology Scenarios

\begin{tabular}{|l|c|c|c|}
\hline \multicolumn{1}{|c|}{ Window Type } & \multicolumn{3}{c|}{ Energy Savings over Current Stock } \\
& Heat, quads & Cool, quads & Total, quads \\
\hline Sales (Business as usual) & 0.03 & 0.17 & 0.20 \\
\hline Low-e & 0.33 & 0.32 & 0.65 \\
\hline Dynamic Low-e & 0.45 & 0.53 & 0.98 \\
\hline Triple Pane Low-e & 0.71 & 0.31 & 1.02 \\
\hline High-R Dynamic & 1.10 & 0.52 & 1.62 \\
\hline
\end{tabular}

We offer the following observations on the potentials in the commercial sector: 
- $\quad$ Significant energy savings from low-e window technology are possible in the commercial buildings sector where the current penetration of low-e technology is modest. Full adoption of low-e technology would save 0.4 to 0.5 quads over sales.

- $\quad$ Both triple pane low-e and dynamic low-e product scenarios offer substantially larger energy savings than what would be possible with low-e products. Either scenario offers potential energy savings of approximately 0.8 quads over sales. Dynamic low-e products appear particularly promising, as they offer peak demand reductions.

- $\quad$ Adding dynamic solar heat gain control to the High-R Superwindow technology scenario dramatically improves cooling season energy performance. We estimate that this scenario offers energy savings of approximately 1.4 quads over the business as usual case.

\section{Uncertainties}

The estimates presented in this paper were developed using the best data and methods available to us. However, these results are strongly dependent on a variety of factors, including especially:

- $\quad$ Estimates of the properties of the current installed window stock.

- Estimates of the properties of today's window sales, as well as those of future products.

- $\quad$ Simplifying assumptions in our methods.

We offer the following cautions. As discussed in the beginning of this paper, the properties of both today's installed window stock and current window sales are poorly characterized. Our estimates of current window stock properties are based on models originally developed by Huang et al. in the mid-1990s. Although we have made an effort to account for the sales of relatively more energy-efficient windows in the intervening time period, we cannot be certain that we have accurately characterized today's window stock. Our estimates of the properties of today's window sales are based on a single proprietary dataset which contains some information gaps; several inferences were required to estimate the properties of today's window sales. Despite this, we believe that estimated properties of today's window sales are less uncertain than those of today's installed window stock. Because of this, we believe that the relative uncertainty in window-related energy savings between "stock" and "sales" scenarios is likely to be greater than the relative uncertainty between "sales" and future scenarios, or between different future scenarios.

Our savings estimates are also a strong function of the basis for the methodology, which is an understanding of heat flows through conventional windows in the current building stock. As product scenarios deviate more and more from conventional products, the uncertainty in our calculations increases. The utilization of solar gains with highly insulating windows, which leads to windows with positive heating energy flows 
offsetting building heating needs from other components, makes theoretical sense but needs to be evaluated in the context of buildings with other advanced components where there may be less overall heating demand. Other methodological issues are rooted in the many simplifying assumptions discussed above, such as:

- $\quad$ Uniform national window properties for the "sales" scenario.

- $\quad$ Window-related loads scale linearly with changes in SHGC and U-factor.

- $\quad$ HVAC-optimized operation of dynamic window products.

- $\quad$ Simplification of US building stock to set of prototypical buildings.

We believe that these methodological issues contribute primarily to uncertainty in the overall estimate of window-related energy consumption, and less so to the relative differences in energy savings potential of various window technology scenarios.

Table 9 - Prototypical Buildings used for Residential and Commercial Analyses

\begin{tabular}{|l|ll|}
\hline \multicolumn{1}{|c|}{ Residential } & \multicolumn{2}{c|}{ Commercial } \\
\hline Considered: & Large Offices & Small Offices \\
Single-family Attached/Detached & Large Hotels & Small Hotels \\
Not Considered (See Text): & Large Retail Stores & Small Retail Stores \\
Mobile Homes & Schools & Hospitals \\
Multi-Family (2-4 Units) & Sit-Down & Fast Food \\
Multi-Family (>4 Units) & Restaurants & Restaurants \\
& Supermarkets & Warehouses \\
\hline
\end{tabular}

Table 10 - Component Loads Simulated by Huang et al.

\begin{tabular}{|c|c|}
\hline Residential & Commercial \\
\hline Window Solar ${ }^{*}$ & Window Solar \\
\hline Window Conduction $^{*}$ & Window Conduction ${ }^{*}$ \\
\hline Infiltration $^{*}$ & Infiltration $^{*}$ \\
\hline Roof & Floor \\
\hline Wall & Ground \\
\hline People & Equipment (Electric/Non-Electric) \\
\hline Equipment & People \\
\hline Ground & Lighting \\
\hline & Outdoor Air \\
\hline
\end{tabular}

\section{Acknowledgements}

The authors wish to thank Joe Huang, Rich Brown, and Christian Kohler for their help during various portions of this work. We thank our two reviewers, Rick Diamond and Robin Mitchell, for their insightful comments. This work was supported by the Assistant Secretary for Energy Efficiency and Renewable Energy, Building Technologies, U.S. Department of Energy under Contract No. DE-AC02-05CH11231. 


\section{Figure 1 - Schematic Overview of Method to Estimate Window \% of Space Conditioning Use}

\section{Original LBNL studies}

(Huang et al., 1999)

- Prototypical buildings to represent entire US stock (developed in early 1990s).

- Used DOE-2 to estimate shell contributions to

loads ("component loads") for each prototype.

\section{Current Study: Window \% of Consumption}

1. Categorize
component loads
developed by Huang et.
al. into window-related
and non-window-related
loads.

2. Update prototypical building populations using CBECS 1999 / RECS 2001. Scale Huang's consumption estimates by $\%$ change in size of building stock.

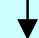

3. Use building-specific efficiency factors to estimate space conditioning energy consumption resulting from component loads.
4. Update Huang's assumptions about window stock properties based on new data.

\section{Scale window-related} energy consumption to account for new assumptions.

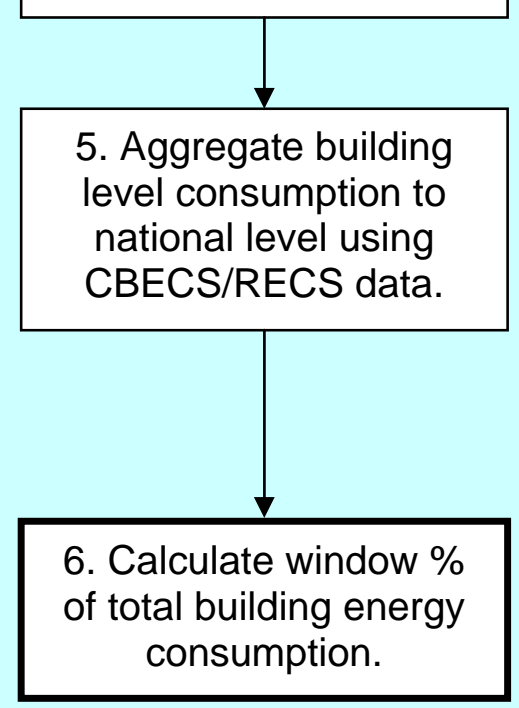




\section{Figure 2 - Template for Estimation of Fraction of Total Loads Attributable to Windows}

\section{Estimate Window Energy Loads by Building Type}

† Sample loads are

fictitious values used to

illustrate calculation procedure

* Cited from Appendix B

3. Convert Aggregate Loads to Percentage of Total Loads

1993 Properties Estimated by Huang, Hanford, et al. (1999)

\begin{tabular}{l|l|l||}
\hline & \\
\hline
\end{tabular}

\begin{tabular}{l|l|l|l|l|l|l} 
& \\
of & $\mathrm{U}$ & & Wind. & Wind. & Other &
\end{tabular}

Sample 2

\begin{tabular}{l|l|l}
100 & 1 & 1
\end{tabular}

1

\begin{tabular}{|l|l|l|l|l|}
\hline 10 & -20 & -20 & -70 & -100 \\
10 & -20 & -20 & -70 & -100
\end{tabular}

00

Before

1979

$1980-$

1031.1

0.72

0.72

$-7.62$

$-8.77$

$-10.04$

$-24.43$

1240.3

2001 Updated Window Stock Estimates (Apte and Arasteh, 2006)

\begin{tabular}{|c|c|c|c|c|c|c|c|c|}
\hline \multirow[b]{2}{*}{$\begin{array}{c}\text { Number of } \\
\text { Buildings } \\
\text { (Thousands, } \\
\text { 2001) }\end{array}$} & \multicolumn{2}{|c|}{$\begin{array}{l}\text { Window } \\
\text { Properties }\end{array}$} & \multicolumn{6}{|c|}{ Total Building Cooling Loads (Trillion BTU/yr) } \\
\hline & $\begin{array}{c}U \\
\text { Factor }\end{array}$ & SHGC & $\begin{array}{l}\text { Wind. } \\
\text { Solar }\end{array}$ & $\begin{array}{l}\text { Wind. } \\
\text { Cond }\end{array}$ & $\begin{array}{l}\text { Wind. } \\
\text { Infilt. }\end{array}$ & $\begin{array}{l}\text { Non. } \\
\text { Wind } \\
\text { Infilt }\end{array}$ & $\begin{array}{l}\text { Other } \\
\text { Loads }\end{array}$ & $\begin{array}{l}\text { Total } \\
\text { Loads }\end{array}$ \\
\hline
\end{tabular}

100

100

200

1175.9

292.0

\begin{tabular}{|c|c|c|c|c|c|c|}
\hline Load Totals & 47.7 & -113.6 & -27.7 & -156.9 & -314.2 & -564.54 \\
\hline Percentage of Total Loads & $-8.5 \%$ & $20.1 \%$ & $4.9 \%$ & $28.0 \%$ & $55.7 \%$ & $100 \%$ \\
\hline Total Window Related Loads & \multicolumn{3}{|c|}{$16.5 \%$ of total loads } & & & \\
\hline $\begin{array}{r}\text { Total Window Energy } \\
\text { Consumption }\end{array}$ & \multicolumn{6}{|c|}{$\begin{array}{c}3 \text { Quads Total Heating * } 16.5 \% \text { of Total Loads = } 0.5 \text { Quads } \\
\text { Window Energy Consumption } \\
\text { (3 Ouads is fictitious value for illustration purposes) }\end{array}$} \\
\hline
\end{tabular}

Three key thematic processes in estimating the total window-related building loads:

1. (Horizontal Axis in Table) - Estimate window-related loads for a particular grouping of similar US residential buildings.

2. $\quad$ (Vertical Axis in Table) - Aggregate window-related loads across entire US residential building population.

3. Convert aggregate loads to percentage of total loads. 


\section{Appendix A - Climate Zones used for Residential Analysis}

Prototypical Single-family Residential buildings were simulated by Huang, Hanford, et al. (1999) in the following climate zones, which we adopted for use.

Figure 3 - Climate Zones Used by Huang et al. for Residential Simulations

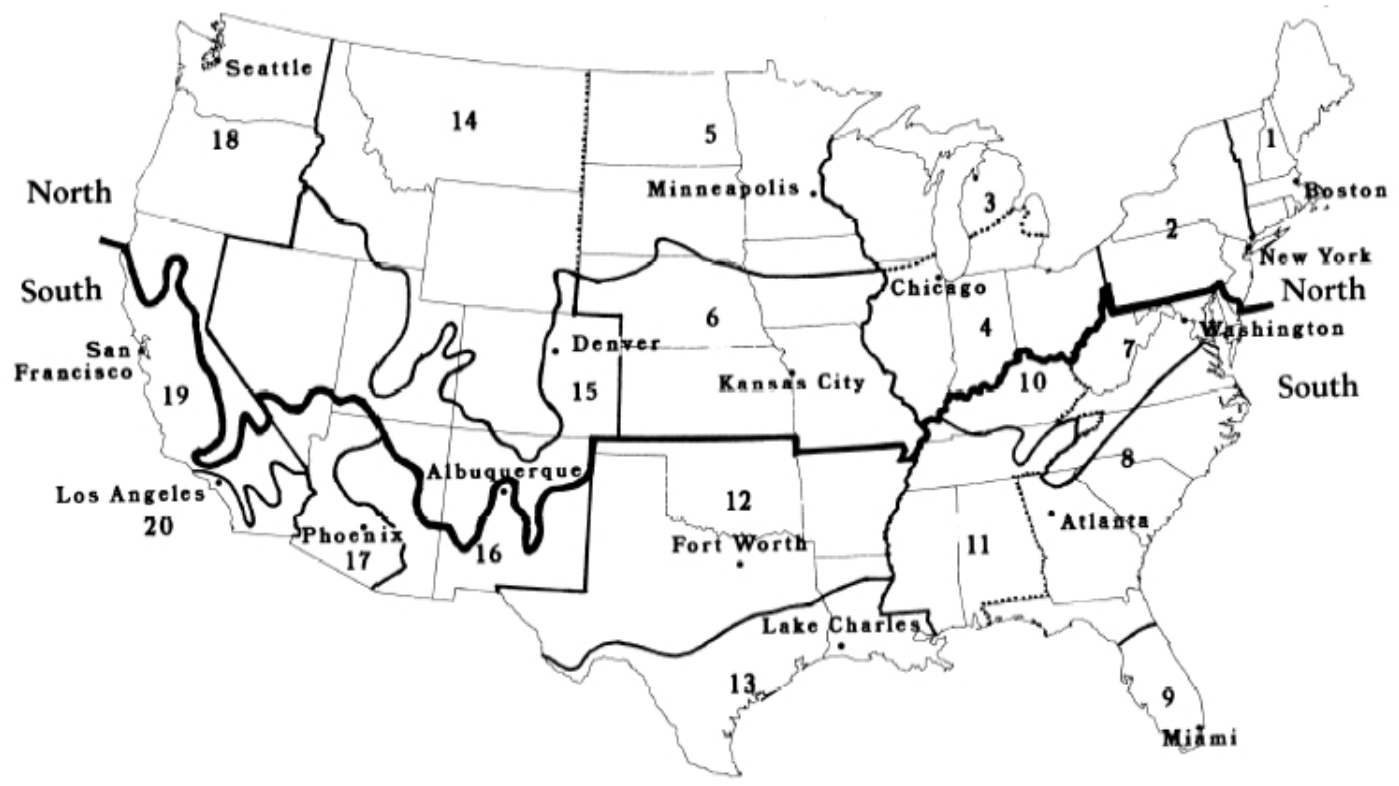

Table 11 - Residential Climate Zone Divisions (after Huang et al, 1999)

\begin{tabular}{|c|c|c|c|c|}
\hline $\begin{array}{c}\text { Climate } \\
\text { Zone }\end{array}$ & $\begin{array}{l}\text { DOE-2 City } \\
(16)\end{array}$ & $\begin{array}{l}\text { Census } \\
\text { Division }\end{array}$ & HDD & CDD \\
\hline 1 & Boston & New England & & \\
\hline 2 & New York & Middle Atlantic & & \\
\hline 3 & Chicago & $\begin{array}{l}\text { East North } \\
\text { Central }\end{array}$ & $<7000$ & \\
\hline 4 & Chicago & $\begin{array}{c}\text { East North } \\
\text { Central }\end{array}$ & $>7000$ & \\
\hline 5 & Minneapolis & $\begin{array}{l}\text { West North } \\
\text { Central }\end{array}$ & $>7000$ & \\
\hline 6 & Kansas City & $\begin{array}{l}\text { West North } \\
\text { Central }\end{array}$ & $<7000$ & \\
\hline 7 & Washington & South Atlantic & $>4000$ & \\
\hline 8 & Atlanta & South Atlantic & $<4000$ & $<3000$ \\
\hline 9 & Miami & South Atlantic & $<4000$ & $>3000$ \\
\hline 10 & Washington & $\begin{array}{c}\text { East South } \\
\text { Central }\end{array}$ & $>4000$ & \\
\hline 11 & Atlanta & $\begin{array}{c}\text { East South } \\
\text { Central }\end{array}$ & $<4000$ & \\
\hline 12 & Fort Worth & $\begin{array}{c}\text { West South } \\
\text { Central }\end{array}$ & $>2000$ & \\
\hline 13 & Lake Charles & $\begin{array}{l}\text { West South } \\
\text { Central }\end{array}$ & $<2000$ & \\
\hline 14 & Minneapolis & Mountain & $>7000$ & \\
\hline 15 & Denver & Mountain & $\begin{array}{l}<7000 \\
>5000\end{array}$ & \\
\hline
\end{tabular}




\begin{tabular}{|c|c|c|c|c|}
\hline 16 & Albuquerque & Mountain & $<5000$ & $<2000$ \\
\hline 17 & Phoenix & Mountain & $<5000$ & $>2000$ \\
\hline 18 & Seattle & Pacific & $>4000$ & \\
\hline 19 & San Francisco & Pacific & $<4000$ & \\
& & & $>2000$ & \\
\hline 20 & Los Angeles & Pacific & $<2000$ & \\
\hline
\end{tabular}




\section{Appendix B - CBECS Climate Zones used by Huang and Franconi (1999)}

Table 12 - Mapping of CBECS Data to Simulations by Huang and Franconi

\begin{tabular}{|c|c|c|c|c|}
\hline $\begin{array}{c}\text { CBECS } \\
\text { Climate } \\
\text { Zone } \\
\text { (Figure 5) }\end{array}$ & CDD Range & HDD Range & $\begin{array}{c}\text { Regional Prototypical } \\
\text { Building Simulated } \\
\text { (Table 13) }\end{array}$ & $\begin{array}{c}\text { TMY Weather } \\
\text { Location }\end{array}$ \\
\hline 1 & $<2000$ & $>7000$ & North & Minneapolis \\
\hline 2 & $<2000$ & $5500-7000$ & North & Chicago \\
\hline 3 & $<2000$ & $4000-4599$ & $\begin{array}{c}\text { North and South } \\
\text { Buildings Simulated, } \\
\text { Results Averaged }\end{array}$ & $\begin{array}{c}\text { Washington, } \\
\text { DC. }\end{array}$ \\
\hline 4 & $<2000$ & $<4000$ & South & Los Angeles \\
\hline 5 & $>2000$ & $<4000$ & South & Houston \\
\hline
\end{tabular}

Table 13 - Prototypical Commercial Buildings (Huang and Franconi, 1999)

\begin{tabular}{|c|c|}
\hline $\begin{array}{c}\text { Building types with single national DOE-2 } \\
\text { prototypical building }\end{array}$ & $\begin{array}{c}\text { Building types with North/South DOE-2 } \\
\text { prototypical buildings }\end{array}$ \\
\hline Large Hotels & Large Offices \\
\hline Small Hotels & Small Offices \\
\hline Fast Food Restaurants & Large Retail Stores \\
\hline Sit-Down Restaurants & Small Retail Stores \\
\hline Hospitals & Schools \\
\hline Supermarkets & Warehouses \\
\hline
\end{tabular}

Figure 4 - North/South Climate Zones for Prototypical Commercial Buildings

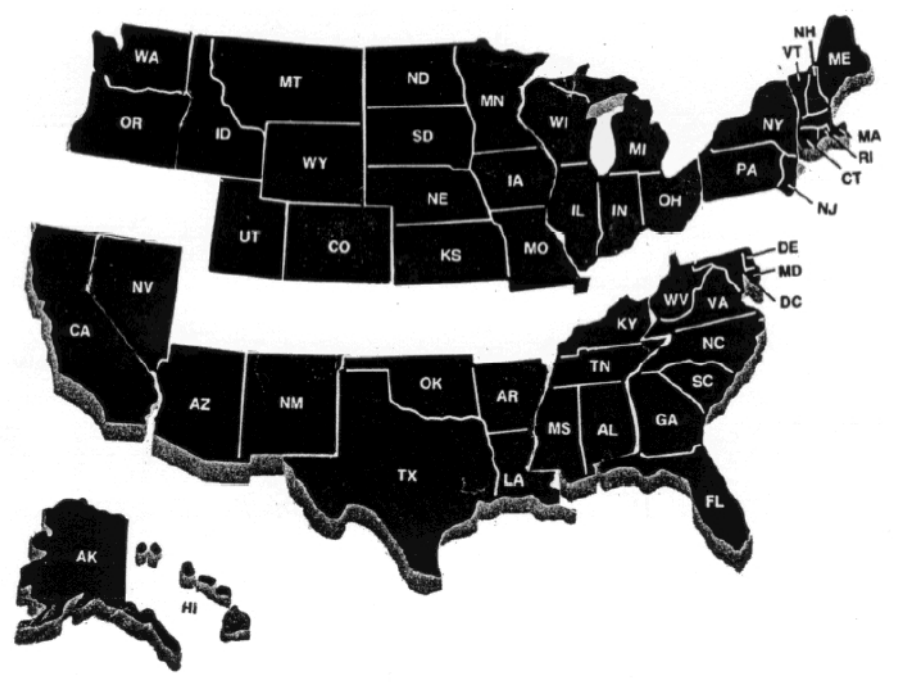

\footnotetext{
${ }^{9}$ As shown in Table 13, prototypical commercial buildings were either developed for both North and South climate zones (Figure 4) or for the entire US stock. See main text for explanation.
} 
Figure 5 - CBECS Climate Zones for DOE-2 Simulation of Prototypical Commercial Buildings

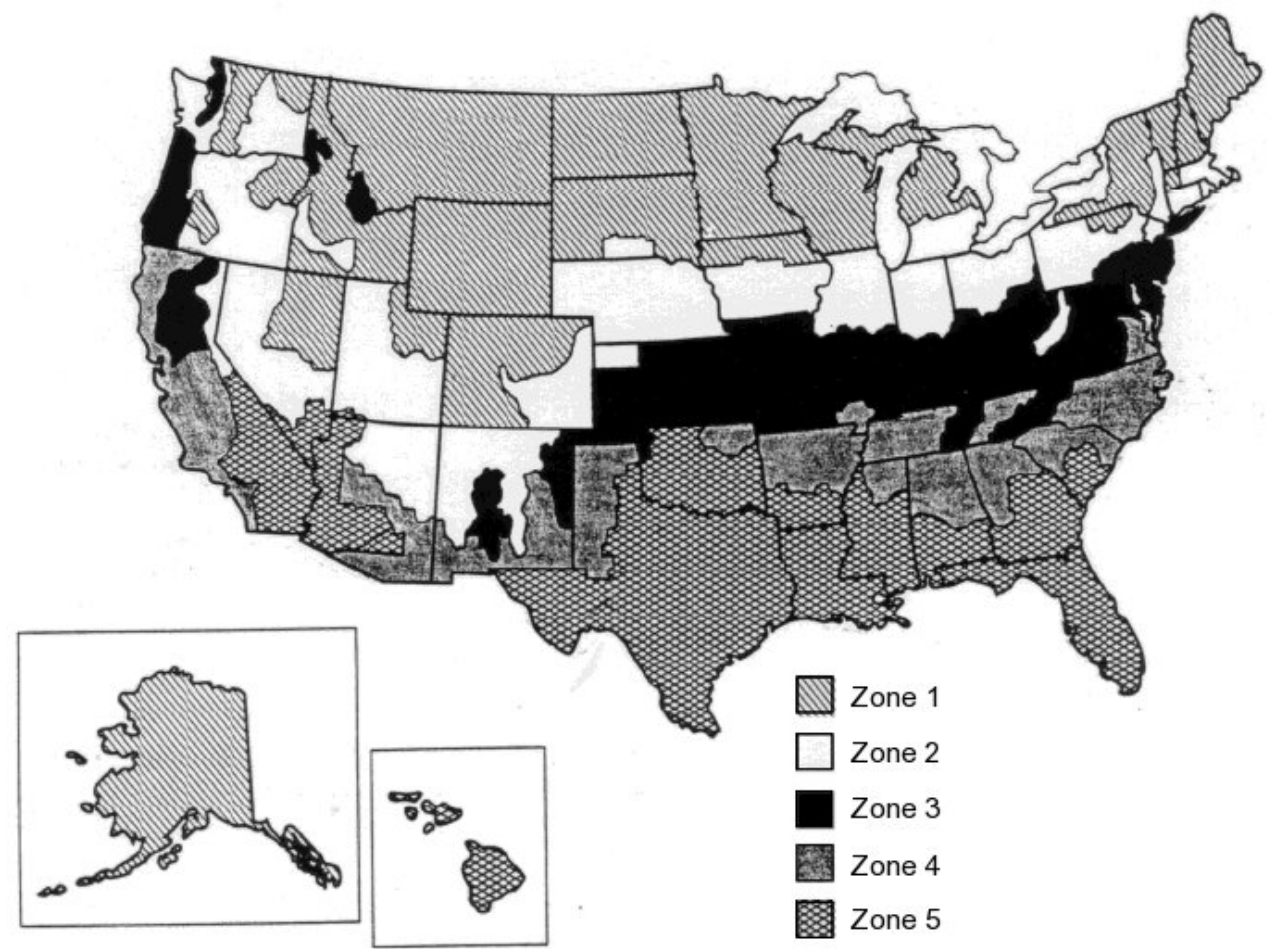

After Huang and Franconi (1999) 


\section{Appendix C - Window Technology Scenario Assumptions}

Residential Sales Scenario

Assumed window properties are presented in Table 14 and were determined as follows. First, we used market survey data to estimate the market shares of dominant window products (Ducker Research Company 2004). Next, we estimated average U-factor and SHGC for typical windows products in each category. We used the following simplifying assumptions:

- All single pane windows use aluminum frames.

- $75 \%$ of double pane (clear) windows have wood/vinyl frames, $25 \%$ have aluminum frames.

- All Double Pane Low-e windows have wood/vinyl frames and low-moderate solar heat gain.

- Triple pane windows have high-performance wood/vinyl frames and moderate solar heat gain.

Based on these assumptions, we used a database of currently available products to estimate typical window properties for each category (Carmody et al. 2000). Finally, we calculated sales-weighted average U-factor and SHGC for current residential window sales.

Table 14 - Assumed Properties of Residential Window Sales

\begin{tabular}{|c|c|c|c|}
\hline Window Type & Percent of Sales & $\begin{array}{c}\text { U - Factor } \\
\text { Btu / }\left(\mathrm{hr}^{-} \mathrm{ft}^{2}{ }^{\circ} \mathrm{F}\right)\end{array}$ & SHGC \\
\hline Single Pane, Clear Glass & $4 \%$ & 1.16 & 0.76 \\
\hline Double Pane, Clear Glass & $40 \%$ & 0.54 & 0.56 \\
\hline Double Pane, Low-e Glass & $54 \%$ & 0.35 & 0.35 \\
\hline Triple Pane, Low-e Glass & $2 \%$ & 0.20 & 0.40 \\
\hline Average Properties & & $\mathbf{0 . 4 6}$ & $\mathbf{0 . 4 5}$ \\
\hline
\end{tabular}

$\underline{\text { Residential Energy Star Scenario }}$

US EPA/DOE's Energy Star program specifies minimum window energy performance standards for windows carrying the Energy Star label. Requirements are specified separately for four climate zones (Figure 6). Table 15 presents Energy Star Window product requirements and assumed window properties by climate zone. We assume that windows just meet the Energy Star specification for U-value. Since low-solar heat gain glazings are now the dominant low-e product in the U.S. (Ducker Research Company 2004), we assume that all low-E windows sold in the US have SHGC $=0.40$, which is required of Energy Star products in the Southern U.S.

As can be seen in Figure 3 and Figure 6, Energy Star climate zones do not overlap perfectly with the climate zones devised by Huang et al. for the simulation of residential prototypical buildings. We mapped each of Huang's climate zones to one Energy Star climate zone, as presented in Table 16. 
Figure 6 - Energy Star Windows Climate Zones

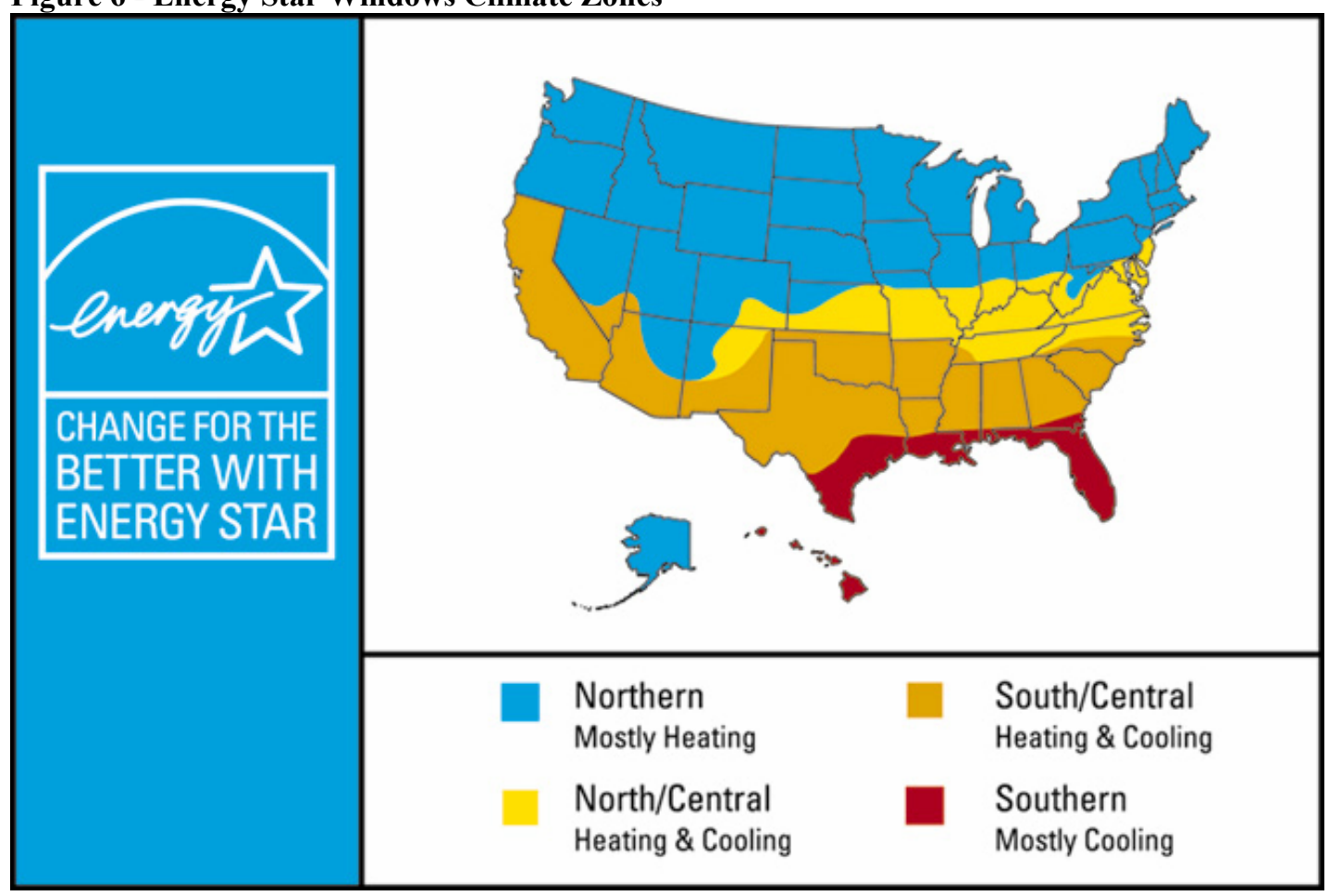

Table 15 - Energy Star Window Assumptions

\begin{tabular}{|c|c|c|c|c|}
\hline \multirow{2}{*}{ Energy Star Climate Zone } & $\begin{array}{c}\text { Energy Star Specification } \\
\text { Requirements }\end{array}$ & \multicolumn{2}{c|}{$\begin{array}{c}\text { Window Properties as } \\
\text { Simulated }\end{array}$} \\
\cline { 2 - 5 } & $\begin{array}{c}\text { U - Factor } \\
\left.\text { Btu / (hr- } \mathrm{ft}^{2}{ }^{\circ} \mathrm{F}\right)\end{array}$ & SHGC & $\begin{array}{c}\text { U - Factor } \\
\text { Btu / }\left(\mathrm{hr}_{-} \mathrm{ft}^{2}{ }^{\circ} \mathrm{F}\right)\end{array}$ & SHGC \\
\hline Northern & $\leq 0.35$ & Any & 0.35 & 0.40 \\
\hline North/Central & $\leq 0.40$ & $\leq 0.55$ & 0.4 & 0.40 \\
\hline South/Central & $\leq 0.40$ & $\leq 0.40$ & 0.4 & 0.40 \\
\hline Southern & $\leq 0.65$ & $\leq 0.40$ & 0.65 & 0.40 \\
\hline
\end{tabular}

Table 16 - Energy Star Climate Zones

\begin{tabular}{|c|c|}
\hline Energy Star Climate Zone & $\begin{array}{c}\text { Corresponding Climate } \\
\text { Zones Used by Huang et al. } \\
\text { (see Appendix A) }\end{array}$ \\
\hline Northern & $1,2,3,4,5,14,15,18$ \\
\hline North/Central & $6,7,10,16$ \\
\hline South/Central & $8,11,12,17,19,20$ \\
\hline Southern & 9,13 \\
\hline
\end{tabular}

Residential Mixed Triple, Dynamic Scenario

The Mixed Triple, Dynamic scenario considers a regionally optimized deployment of windows from the Dynamic Low-e and Triple Pane Low-e scenarios, as described in the main text. Specifically, we assumed that windows from the Triple Pane Low-e scenario 
were installed in the climate zones simulated by Huang et al. corresponding to the Northern and North/Central Energy Star Climate Zones. Dynamic Low-e Scenario were assumed to have been installed in the Southern and South/Central Energy Star Climate Zones.

\section{Commercial Sales Scenario}

Assumed window properties for the commercial sales scenario are presented in Table 14 and were determined as follows. First, we used market survey data to estimate the market shares of dominant window glazing types (Ducker Research Company 2004). Next, we assumed that all commercial glazings were installed in aluminum curtain wall frames, and assumed typical ASHRAE U-factor and SHGC for this type of installation (ASHRAE 2005) ${ }^{10}$. Based on these assumptions, we calculated sales-weighted average U-Factor and SHGC for commercial windows sales.

Table 17 - Assumed Properties of Commercial Window Sales

\begin{tabular}{|c|c|c|c|}
\hline Window Type & $\begin{array}{c}\text { Percent of } \\
\text { Sales }\end{array}$ & $\begin{array}{c}\text { U - Factor } \\
\text { Btu / }\left(\mathrm{hr}^{-\mathrm{ft}^{2}-}{ }^{\circ} \mathrm{F}\right)\end{array}$ & SHGC \\
\hline Single Pane, Clear Glass & $11 \%$ & 1.16 & 0.74 \\
\hline Double Pane, Clear Glass & $30 \%$ & 0.62 & 0.63 \\
\hline Double Pane, Tinted Glass & $6 \%$ & 0.65 & 0.13 \\
\hline Double Pane, Reflective Glass & $20 \%$ & 0.62 & 0.46 \\
\hline Double Pane, Low-e Glass & $30 \%$ & 0.51 & 0.34 \\
\hline Triple Pane, Low-e Glass & $3 \%$ & 0.51 & 0.34 \\
\hline Average Properties & $\mathbf{1 0 0 \%}$ & $\mathbf{0 . 6 4}$ & $\mathbf{0 . 4 8}$ \\
\hline
\end{tabular}

\footnotetext{
${ }^{10}$ This assumption provides a conservative estimate of window savings from this scenario; if some glazings are installed in more energy-efficient frames, energy savings would be higher.
} 


\section{Appendix D - Complete Residential Results}

Heating Loads

\begin{tabular}{|c|c|c|c|c|c|c|c|c|c|c|c|c|}
\hline & & & 991 Prope & rties Estim & ated by Hu & uang, $\mathrm{Han}$ & ford, et al (19) & & & & & 2001 Upda \\
\hline Climate & & & Window & Properties & & tal Building & Heating Load & (Trillion BT & TU/yr) & & Window $\mathrm{P}$ & operties \\
\hline Zone & Year Made & $\begin{array}{c}\text { Number of Buildings } \\
\text { (Thousands, 1993) }\end{array}$ & $\underset{\text { Factor }}{u}$ & SHGC & $\begin{array}{c}\text { Window } \\
\text { Solar }\end{array}$ & $\begin{array}{c}\text { Window } \\
\text { Cond }\end{array}$ & Infiltration & $\begin{array}{l}\text { Other } \\
\text { Loads }\end{array}$ & Total Loads & $\begin{array}{c}\text { Number of Buildings } \\
\text { (Thousands, 2001) }\end{array}$ & U Factor & SHGC \\
\hline & 1 Before 1950 & 1217.5 & 0.55 & $\begin{array}{ll}0.67 \\
\end{array}$ & 7.65 & -18.3 & -34.15 & -38.11 & -82.91 & 1175.9 & 0.55 & 0.65 \\
\hline & $1950-1979$ & 1031.1 & 0.72 & 0.72 & 8.04 & -31.59 & -32.72 & -34.48 & -90.75 & 1292.0 & 0.61 & 0.66 \\
\hline & 1 1980-1989 & 326 & 0.72 & 0.72 & 1.69 & -6.36 & -7.95 & -8 & -20.62 & 369.2 & 0.61 & 0.66 \\
\hline & After 1989 & 135.2 & 0.50 & 0.61 & 0.04 & -2.41 & -3.04 & -1.64 & -7.05 & 226.4 & 0.46 & 0.59 \\
\hline & Before 1950 & 2360.9 & 0.55 & 0.67 & 1234 & -30.28 & -59.96 & -64.79 & -142.69 & 2132.7 & 0.55 & 0.65 \\
\hline & 1950-1979 & 3477.5 & 0.72 & 0.72 & 19.83 & -85.15 & -94 & -101.5 & -260.82 & 2807.8 & 0.61 & 0.66 \\
\hline & 1980-1989 & 788.8 & 0.72 & 0.72 & 2.95 & -13.47 & -19.04 & -8.93 & -38.49 & 637.1 & 0.61 & 0.66 \\
\hline & After 1989 & 212.6 & 0.50 & 0.61 & 0 & -3.34 & -4.78 & -2.26 & -10.38 & 536.4 & 0.46 & 0.59 \\
\hline & 3 Before 1950 & 961.6 & 0.55 & 0.67 & 7.23 & -17.71 & -30.31 & -38.31 & -79.1 & 3660.2 & 0.55 & 0.65 \\
\hline & 3 1950-1979 & 1238.4 & 0.72 & 0.72 & 4.75 & -24.12 & -23.72 & -35.75 & -78.84 & 4153.9 & 0.61 & 0.66 \\
\hline & В 1980-1989 & 355.9 & 0.72 & 0.72 & 2 & -7.62 & -8.77 & -10.04 & -24.43 & 1240.3 & 0.61 & 0.66 \\
\hline & 3 After 1989 & 203.8 & 0.50 & 0.61 & 0.08 & -4.19 & -4.87 & -3.19 & -12.17 & 1368.8 & 0.46 & 0.59 \\
\hline & 4 Before 1950 & 3409.1 & 0.55 & 0.67 & 25.57 & -62.6 & -107.15 & -135.48 & -279.66 & 0.0 & 0.55 & 0.65 \\
\hline & $41950-1979$ & 3757 & 0.72 & 0.72 & 14.71 & -74.78 & -73.54 & -110.83 & -244.44 & 0.0 & 0.61 & 0.66 \\
\hline & 1980-1989 & 591.8 & 0.72 & 0.72 & 3.46 & -13.21 & -15.2 & -17.39 & -42.34 & 0.0 & 0.61 & 0.66 \\
\hline & After 1989 & 276.4 & 0.50 & 0.61 & 0.11 & -5.96 & -6.93 & -4.55 & -17.33 & 0.0 & 0.46 & 0.59 \\
\hline & 5 Before 1950 & 1414.6 & 0.55 & 0.67 & 10.76 & -31.53 & -52.1 & -71.88 & -144.75 & 852.4 & 0.55 & 0.65 \\
\hline & $1950-1979$ & 772 & 0.72 & 0.72 & 2.15 & -16.02 & -15.45 & -26.75 & -56.07 & 511.6 & 0.61 & 0.66 \\
\hline & 1980-1989 & 47.3 & 0.72 & 0.72 & 0.23 & -1.09 & -1.41 & -1.22 & -3.49 & 148.8 & 0.61 & 0.66 \\
\hline & After 1989 & 103.6 & 0.50 & 0.61 & -0.06 & -2.28 & -2.1 & -1.64 & -6.08 & 49.4 & 0.46 & 0.59 \\
\hline & Before 1950 & 1051.2 & 0.55 & 0.67 & 6.87 & -13.92 & -20.94 & -27.32 & -55.31 & 1287.7 & 0.55 & 0.65 \\
\hline & s $1950-1979$ & 901.4 & 0.72 & 0.72 & 2.93 & -11.03 & -9.83 & -14.83 & -32.76 & 1428.9 & 0.61 & 0.66 \\
\hline & $1980-1989$ & 350.6 & 0.72 & 0.72 & 2.23 & -6.24 & -6.5 & -7.66 & -18.17 & 433.9 & 0.61 & 0.66 \\
\hline & After 1989 & 196.6 & 0.50 & 0.61 & 0.32 & -2.93 & -3.07 & -1.87 & -7.55 & 314.0 & 0.46 & 0.59 \\
\hline & Before 1950 & 1655.3 & 1.02 & 0.75 & 12.24 & -32.18 & -30.52 & -44.48 & -94.94 & 624.7 & 0.94 & 0.72 \\
\hline & $1950-1979$ & 3556 & 1.28 & 0.81 & 34.47 & -113.07 & -70.39 & -101.99 & -250.98 & 1118.6 & 1.06 & 0.73 \\
\hline & 7 1980-1989 & 1058.5 & 0.72 & 0.72 & 5.42 & -17.25 & -17.03 & -10.33 & -39.19 & 436.2 & 0.61 & 0.66 \\
\hline & After 1989 & 551.5 & 0.50 & 0.61 & 0.72 & -8.61 & -9.15 & -5.1 & -22.14 & 394.8 & 0.46 & 0.59 \\
\hline & B Before 1950 & 166.3 & 1.02 & 0.76 & 0.65 & -2.19 & -2.36 & -2.76 & -6.66 & 1149.8 & 0.94 & 0.72 \\
\hline & 3 1950-1979 & 806.5 & 1.28 & 0.81 & 4.08 & -16.31 & -11.3 & -9.17 & -32.7 & 3125.4 & 1.06 & 0.73 \\
\hline & 3 1980-1989 & 189.9 & 0.72 & 0.72 & 0.83 & -2.03 & -2.13 & -1.29 & -4.62 & 1130.8 & 0.61 & 0.66 \\
\hline & B After 1989 & 585.4 & 0.66 & 0.68 & 2.54 & -5.27 & -6.3 & -3.14 & $-12.17 \|$ & 1690.3 & 0.59 & 0.65 \\
\hline & Before 1950 & 114.1 & 0.55 & 0.67 & 0.04 & -0.11 & -0.11 & -0.13 & -0.31 & 67.2 & 0.55 & 0.65 \\
\hline & 1950-1979 & 924.1 & 0.72 & 0.72 & 0.41 & -1.18 & -0.74 & -0.35 & -1.86 & 1274.8 & 0.61 & 0.66 \\
\hline & 1980-1989 & 803.8 & 1.28 & 0.81 & 0.23 & -0.57 & -0.38 & 0.08 & -0.64 & 929.8 & 1.06 & 0.73 \\
\hline & After 1989 & 185.7 & 1.13 & 0.77 & 0.06 & -0.13 & -0.09 & 0.03 & -0.13 & 441.0 & 0.98 & 0.72 \\
\hline & Before 1950 & 1110.1 & 1.02 & 0.75 & 4.29 & -14.43 & -15.54 & -18.23 & -43.91 & 213.3 & 0.94 & 0.72 \\
\hline & $1950-1979$ & 2023.3 & 1.28 & 0.81 & 10.08 & -40.29 & -27.93 & -22.65 & -80.79 & 246.5 & 1.06 & 0.73 \\
\hline & $1980-1989$ & 540.1 & 0.72 & 0.72 & 2.3 & -5.59 & -5.87 & -3.61 & -12.77 & 194.3 & 0.61 & 0.66 \\
\hline & After 1989 & 259.5 & 0.50 & 0.61 & 1.24 & -2.57 & -3.08 & -1.53 & -5.94 & 251.5 & 0.46 & 0.59 \\
\hline & 1 Before 1950 & 62.9 & 1.02 & 0.76 & 0.15 & -0.37 & -0.37 & -0.51 & -1.1 & 975.2 & 0.94 & 0.72 \\
\hline & $1950-1979$ & 380.6 & 1.28 & 0.81 & 1.28 & -3.15 & -1.91 & -1.05 & -4.83 & 1600.6 & 1.06 & 0.73 \\
\hline & $1980-1989$ & 104.9 & 0.72 & 0.72 & 0.31 & -0.72 & -0.5 & -0.17 & -1.08 & 700.7 & 0.61 & 0.66 \\
\hline & After 1989 & 23.8 & 0.66 & 0.68 & 0.08 & -0.17 & -0.13 & -0.01 & -0.23 & 643.7 & 0.59 & 0.65 \\
\hline & 2 Before 1950 & 1449.4 & 1.02 & 0.76 & 5.2 & -12.34 & -13.65 & -18.92 & -39.71 & 1266.9 & 0.94 & 0.72 \\
\hline & 1950-1979 & 3268.1 & 1.28 & 0.81 & 17 & -42.72 & -28.18 & -21.88 & -75.78 & 2015.3 & 1.06 & 0.73 \\
\hline & 2 1980-1989 & 1424.8 & 1.28 & 0.81 & 6.05 & -14.89 & -11.29 & -4.36 & -24.49 & 704.7 & 1.06 & 0.73 \\
\hline & After 1989 & 427.5 & 1.13 & 0.77 & 2.11 & -4.83 & -3.84 & -1.46 & -8.02 & 681.7 & 0.98 & 0.72 \\
\hline & Before 1950 & 103.5 & 1.02 & 0.76 & 0.25 & -0.6 & -0.59 & -0.83 & -1.77 & 466.1 & 0.94 & 0.72 \\
\hline & 3 1950-1979 & 346.9 & 1.28 & 0.81 & 1.17 & -2.87 & -1.75 & -0.95 & -4.4 & 1816.0 & 1.06 & 0.73 \\
\hline & 3 1980-1989 & 180.2 & 1.28 & 0.81 & 0.54 & -1.25 & -0.87 & -0.3 & $-1.88 \|$ & 516.6 & 1.06 & 0.73 \\
\hline & 4 Before 1950 & 383.6 & 0.55 & 0.67 & 3.06 & -6.65 & -5.69 & -12.54 & -21.82 & 270.9 & 0.55 & 0.65 \\
\hline & $41950-1979$ & 586.3 & 0.72 & 0.72 & 4.56 & -11.93 & -6.92 & -9.78 & -24.07 & 392.6 & 0.61 & 0.66 \\
\hline & 4 1980-1989 & 142.7 & 0.72 & 0.72 & 1.54 & -2.92 & -2.44 & -2.42 & -6.24 & 11.9 & 0.61 & 0.66 \\
\hline & 4 After 1989 & 94.1 & 0.50 & 0.61 & 0.58 & -1.83 & -1.55 & -1.32 & -4.12 & 51.2 & 0.46 & 0.59 \\
\hline & Before 1950 & 202.6 & 1.02 & 0.75 & 1.56 & -3.4 & -2.91 & -6.41 & -11.16 & 326.1 & 0.94 & 0.72 \\
\hline & $1950-1979$ & 535.1 & 1.28 & 0.81 & 3.84 & -10.05 & -5.83 & -8.22 & -20.26 & 626.0 & 1.06 & 0.73 \\
\hline & 1980-1989 & 34.6 & 0.72 & 0.72 & 0.32 & -0.61 & -0.51 & -0.5 & -1.3 & 211.0 & 0.61 & 0.66 \\
\hline & 5 After 1989 & 75.8 & 0.50 & 0.61 & 0.39 & -1.24 & -1.05 & -0.89 & -2.79 & 575.6 & 0.46 & 0.59 \\
\hline & Before 1950 & 70.4 & $\begin{array}{l}0.02 \\
1.02\end{array}$ & 0.75 & 0.5 & -0.91 & -0.74 & -1.59 & -2.74 & 64.7 & 0.94 & 0.72 \\
\hline & $1950-1979$ & 335.5 & 1.28 & 0.81 & 2.26 & -4.73 & -2.67 & -3.33 & -8.47 & 181.7 & 1.06 & 0.73 \\
\hline & 1980-1989 & 74.3 & 0.72 & 0.72 & 0.39 & -0.67 & -0.67 & -0.51 & -1.46 & 0.0 & 0.61 & 0.66 \\
\hline & After 1989 & 28.5 & 0.50 & 0.61 & 0.1 & -0.26 & -0.28 & -0.22 & -0.66 & 13.0 & 0.46 & 0.59 \\
\hline & Before 1950 & 115.3 & 1.02 & 0.75 & 0.24 & -0.44 & -0.34 & -0.74 & -1.28 & 154.7 & 0.94 & 0.72 \\
\hline & 1950-1979 & 482.8 & 1.28 & 0.81 & 1.18 & -2.03 & -1.17 & -0.93 & -2.95 & 814.4 & 1.06 & 0.73 \\
\hline & 7 1980-1989 & 100.3 & 0.72 & 0.72 & 0.17 & -0.25 & -0.25 & -0.1 & -0.43 & 179.8 & 0.61 & 0.66 \\
\hline & Before 1950 & 997.4 & 0.55 & 0.67 & 4.42 & -16.96 & -28.53 & -29.92 & -70.99 & 432.7 & 0.55 & 0.65 \\
\hline & 3 1950-1979 & 966.9 & 0.72 & 0.72 & 3.6 & -23.37 & -22 & -17.99 & -59.76 & 1214.8 & 0.61 & 0.66 \\
\hline & 3 1980-1989 & 531.7 & 0.72 & 0.72 & 3.08 & -13.82 & -9.44 & -2.6 & -22.78 & 308.3 & 0.61 & 0.66 \\
\hline & After 1989 & 205.6 & 0.50 & 0.61 & -0.01 & -5.05 & -3.65 & -0.38 & -9.09 & 398.7 & 0.46 & 0.59 \\
\hline & Before 1950 & 690 & 1.02 & 0.76 & 7 & -12.44 & -12.43 & -18.32 & -36.19 & 494.2 & 0.94 & 0.72 \\
\hline & $1950-1979$ & 1642.4 & 1.28 & 0.81 & 15.69 & -30.44 & -19.28 & -25.11 & -59.14 & 1537.4 & 1.06 & 0.73 \\
\hline & 1980-1989 & 482.2 & 0.72 & 0.72 & 6.65 & -6.69 & -4.85 & -5.04 & -9.93 & 284.1 & 0.61 & 0.66 \\
\hline & After 1989 & 75.9 & 0.66 & 0.68 & 1.05 & -0.95 & -0.77 & -0.53 & -1.2 & 431.3 & 0.59 & 0.65 \\
\hline & Before 1950 & 592 & 1.02 & 0.76 & 2.91 & -4.67 & -4.01 & -7.48 & -13.25 & 927.0 & 0.94 & 0.72 \\
\hline & $1950-1979$ & 1961.1 & 1.28 & 0.81 & 11.13 & -18.78 & -10.39 & -15.95 & -33.99 & 2110.2 & 1.06 & 0.73 \\
\hline & 1980-1989 & 283.4 & 0.72 & 0.72 & 2.07 & -1.85 & -1.23 & -1.03 & $-2.04 \|$ & 287.4 & 0.61 & 0.66 \\
\hline & After 1989 & 56.5 & 0.66 & 0.68 & 0.51 & -0.4 & -0.3 & -0.19 & -0.38 & 552.9 & 0.59 & 0.65 \\
\hline & & & \begin{tabular}{|l|} 
Window \\
\end{tabular} & Properties & & tal Building & Heating Load & (Trillion BT & TU/yr) & & Window $\mathrm{P}$ & operties \\
\hline Totals & /Averages & Number of Buildings & \begin{tabular}{c|c|}
$U$ \\
\end{tabular} & SHGC & Window & Window & Infiltration & Other & \begin{tabular}{|l||} 
Total Loads \\
\end{tabular} & $\begin{array}{l}\text { Number of Buildings } \\
\text { (Thousands. 2001) }\end{array}$ & U Factor & SHGC \\
\hline Total & & $\frac{\text { (Inousanas, 1993) }}{59230.60}$ & \begin{tabular}{|c|} 
Factor \\
0.85
\end{tabular} & 0.73 & \begin{tabular}{|l|} 
Solar | \\
328.41 \\
\end{tabular} & $\frac{1015.16}{-1016}$ & -1053.43 & $\frac{\text { Loads }}{-1217.55}$ & -2957.73 & \begin{tabular}{|r|} 
(Inousanas, 2001$)$ \\
62156.65
\end{tabular} & 0.74 & 0.68 \\
\hline Percentag & e of Total Lo & & & & $-11 \%$ & $34 \%$ & $36 \%$ & $41 \%$ & $100 \%$ & & & \\
\hline & Windows 15 & $\%$ of total infiltration & $\begin{array}{l}\text { Window } \\
\text { Window }\end{array}$ & $\begin{array}{l}\text { otal } \\
\text { of Total }\end{array}$ & $\begin{array}{r}-844.76 \mathrm{~T} \\
29 \%\end{array}$ & Trillion B & J Loads & & & & $\begin{array}{l}\text { Window Tota } \\
\text { Window \% of } \\
\text { Total Quads } \\
\text { Total Quads }\end{array}$ & $\begin{array}{l}\text { eat } \\
\text { indow Heat } \\
\text { indol }\end{array}$ \\
\hline
\end{tabular}


Cooling Loads

\begin{tabular}{|c|c|c|c|c|c|c|c|c|c|c|c|c|c|c|c|c|c|c|}
\hline & & & 1993 Prope & rties Estin & nated by & Huang, Hanf & ford, et al (19 & & & & 20011 & pdated Wii & ndow Stock & k Estimates & (Apte and Ara & isteh, 2006) & & \\
\hline & & & Window & Properties & & otal Building & Cooling Load & $\frac{1 \text { STrillion B }}{S \text { S }}$ & TU/yr) & & \begin{tabular}{|l|l|} 
Window \\
\end{tabular} & roperties & & Total B & ülding Cooling & Loads (Trillion B & & \\
\hline $\begin{array}{l}\text { Cime } \\
\text { zone }\end{array}$ & Year Made & $\begin{array}{l}\text { Number of Buildings } \\
\text { (Thousands, 1993) }\end{array}$ & $\begin{array}{c}u \\
\text { Factor }\end{array}$ & SHGC & \begin{tabular}{|c} 
Window \\
Solar
\end{tabular} & \begin{tabular}{|c|} 
Window \\
Cond
\end{tabular} & Infiltration & $\begin{array}{l}\text { Other } \\
\text { Loads }\end{array}$ & Total Loads & $\begin{array}{l}\text { Number of Buildings } \\
\text { (Thousands, 2001) }\end{array}$ & U Factor & SHGC & $\begin{array}{l}\text { Window } \\
\text { Solar }\end{array}$ & \begin{tabular}{|c} 
Window \\
Cond
\end{tabular} & $\begin{array}{c}\text { Window } \\
\text { Infiltration }\end{array}$ & \begin{tabular}{|c|} 
Non-Window \\
Infiltration
\end{tabular} & $\begin{array}{l}\text { Other } \\
\text { Loads }\end{array}$ & $\begin{array}{l}\text { Total } \\
\text { Loads }\end{array}$ \\
\hline & 1 Before 1950 & 1217.5 & 0.55 & 0.67 & 2.04 & -0.1 & -20.21 & -17.6 & -82.91 & 1175.9 & 0.55 & & -0.10 & 1.91 & 0.10 & 0.57 & 2.06 & 4.54 \\
\hline & 1 1950-1979 & 1031.1 & 0.72 & 0.72 & 8.04 & -31.59 & -32.72 & -34.48 & -90.75 & 1292.0 & 0.61 & 0.66 & -0.07 & 3.21 & 0.13 & 0.73 & 0.44 & 4.44 \\
\hline & & & & 0.72 & 1.69 & & & & -20.62 & 369.2 & & 0.66 & 0.01 & 0.61 & 0.03 & 0.17 & 0.27 & 1.09 \\
\hline & 1 After 1989 & 135.2 & 0.50 & 0.61 & 0.04 & -2.41 & -3.04 & -1.64 & -7.05 & 226.4 & 0.46 & 0.59 & 0.02 & 0.41 & 0.02 & 0.10 & -0.04 & 0.50 \\
\hline & 2 Before 1950 & 2360.9 & 0.55 & 0.67 & 12.34 & -30.28 & -59.96 & -64.79 & -142.69 & 2132.7 & 0.55 & 0.65 & -0.26 & 3.99 & 0.27 & 1.52 & 6.98 & 12.50 \\
\hline & 2 1950-1979 & 3477.5 & 0.72 & 0.72 & 19.83 & -85.15 & -94 & -101.5 & & 2807.8 & 0.61 & 0.66 & 0.04 & 11.25 & 0.58 & 3.26 & 16.20 & 31.32 \\
\hline & 2 1980-1989 & 788.8 & 0.72 & 0.72 & 2.95 & -13.47 & -19.04 & -8.93 & -38.49 & 637.1 & 0.61 & 0.66 & -0.02 & 1.71 & 0.10 & 0.59 & 2.94 & 5.32 \\
\hline & 2 After 1989 & 212.6 & 0.50 & 0.61 & 0 & -3.34 & -4.78 & -2.26 & -10.38 & 536.4 & 0.46 & 0.59 & 0.07 & 1.01 & 0.06 & 0.34 & -0.51 & 0.97 \\
\hline & 3 Before 1950 & 961.6 & 0.55 & 0.67 & 7.23 & -17.71 & -30.31 & -38.31 & -79.1 & 3660.2 & 0.55 & 0.65 & -0.61 & 10.70 & 0.65 & 3.69 & -7.59 & 6.85 \\
\hline & 3 1950-1979 & 1238.4 & 0.72 & 0.72 & 4.75 & -24.12 & -23.72 & -35.75 & -78.84 & 4153.9 & 0.61 & 0.66 & 0.40 & 9.53 & 0.53 & 2.99 & -7.71 & 5.74 \\
\hline & 3 1980-1989 & 355.9 & 0.72 & 0.72 & 2 & -7.62 & -8.77 & -10.04 & -24.43 & 1240.3 & 0.61 & 0.66 & 0.80 & 4.33 & 0.24 & 1.33 & -4.28 & 2.42 \\
\hline & 3 After 1989 & $\begin{array}{r}203.8 \\
24091\end{array}$ & 0.50 & 0.61 & 0.08 & -4.19 & $\begin{array}{r}-4.87 \\
\end{array}$ & $\begin{array}{r}-3.19 \\
-155\end{array}$ & -12.17 & 1368.8 & 0.46 & 0.59 & 0.37 & 6.29 & 0.31 & 1.77 & -6.85 & 1.89 \\
\hline & $\begin{array}{l}4 \text { Before } 1950 \\
4 \text { 1950-1979 }\end{array}$ & $\begin{aligned} 3409.1 \\
3757\end{aligned}$ & $\begin{array}{l}0.55 \\
0.72\end{array}$ & $\begin{array}{l}0.67 \\
0.72\end{array}$ & $\begin{array}{l}25.57 \\
14.71\end{array}$ & $\begin{array}{r}-62.6 \\
-74.78\end{array}$ & $\begin{array}{r}-107.15 \\
-7354\end{array}$ & $\begin{array}{l}-135.48 \\
-11083\end{array}$ & $\begin{array}{l}-279.66 \\
-244.44\end{array}$ & $\begin{array}{l}0.0 \\
0.0\end{array}$ & $\begin{array}{l}0.55 \\
0.61\end{array}$ & 0.65 & 0.00 & 0.00 & 0.00 & 0.00 & $\begin{array}{l}28.89 \\
25.71\end{array}$ & 28.89 \\
\hline & 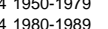 & $\begin{array}{r}3577 \\
5918\end{array}$ & $\begin{array}{l}0.72 \\
0.72\end{array}$ & $\begin{array}{l}0.72 \\
0.72\end{array}$ & $\begin{array}{r}14.71 \\
3.46\end{array}$ & $\begin{array}{l}-74.78 \\
-{ }_{-13.21}\end{array}$ & $\begin{array}{l}-7.354 \\
-15.2 \\
-\end{array}$ & $\begin{aligned}-110.83 \\
-17.39 \\
-\end{aligned}$ & $\begin{array}{l}-244.44 \\
-4234\end{array}$ & $\begin{array}{l}0.0 \\
0.0\end{array}$ & $\begin{array}{l}0.61 \\
0.61\end{array}$ & $\begin{array}{l}0.66 \\
0.66\end{array}$ & $\begin{array}{l}0.00 \\
0.00\end{array}$ & $\begin{array}{l}0.00 \\
0.00\end{array}$ & 0.00 & $\begin{array}{l}0.00 \\
0.00\end{array}$ & $\begin{array}{r}25.71 \\
5.49\end{array}$ & $\begin{array}{r}25.71 \\
5.49\end{array}$ \\
\hline & $\begin{array}{l}4.4800-1989 \\
4 \text { After } 1989\end{array}$ & $\begin{array}{l}591.8 \\
2764\end{array}$ & $\begin{array}{l}0.12 \\
0.50\end{array}$ & 0.61 & 0.46 & $\begin{array}{l}-13.21 \\
-5.96 \\
-51\end{array}$ & $\begin{array}{l}-15.2 \\
-6.93 \\
\end{array}$ & -455 & $\begin{array}{l}-42.34 \\
-1733\end{array}$ & 0.0 & 0.46 & $\begin{array}{l}0.06 \\
0.59\end{array}$ & $\begin{array}{l}0.00 \\
0.00\end{array}$ & 0.00 & 0.00 & 0.00 & $\begin{array}{l}5.49 \\
2.48\end{array}$ & $\begin{array}{l}5.49 \\
2.48 \\
-\end{array}$ \\
\hline & 5 Before 1950 & 1414.6 & 0.55 & 0.67 & 10.76 & $\begin{array}{r}-0.90 \\
-31.53\end{array}$ & -52.1 & -71.88 & -144.75 & 85.4 & 0.45 & . & -016 & 324 & 0.18 & 100 & 778 & 1204 \\
\hline & 5 1950-1979 & 772 & 0.72 & 0.72 & 2.15 & $\begin{array}{l}-16.02 \\
-1.02\end{array}$ & -15.45 & -26.75 & -56.07 & $\begin{array}{l}511.6 \\
51.6\end{array}$ & 0.61 & 0.66 & 0.06 & $\begin{array}{l}0.1 .7 \\
1.7\end{array}$ & 0.06 & 0.35 & 2.40 & $\begin{array}{r}42.04 \\
4.04\end{array}$ \\
\hline & 5 1980-1989 & 47.3 & 0.72 & 0.72 & 0.23 & -1.09 & -1.41 & -1.22 & -3.49 & 148.8 & 0.61 & 0.66 & 0.00 & 0.46 & 0.02 & 0.13 & $\begin{array}{l}-.437 \\
-0.37\end{array}$ & 0.25 \\
\hline & 5 Atter 1989 & 103.6 & 0.50 & 0.61 & -0.06 & -2.28 & -2.1 & -1.64 & -6.08 & 49.4 & 0.46 & 0.59 & 0.01 & 0.16 & 0.01 & 0.04 & 0.46 & 0.67 \\
\hline & 6 Before 1950 & 1051.2 & 0.55 & 0.67 & 6.87 & -13.92 & -20.94 & -27.32 & -55.31 & 1287.7 & 0.55 & 0.65 & -0.19 & 9.94 & 0.88 & 4.99 & 8.76 & 24.38 \\
\hline & 6 1950-1979 & 901.4 & 0.72 & 0.72 & 2.93 & -11.03 & -9.83 & -14.83 & -32.76 & 1428.9 & 0.61 & 0.66 & 0.55 & 7.65 & 0.60 & 3.38 & 2.12 & 14.30 \\
\hline & 6 1980-1989 & 350.6 & 0.72 & 0.72 & 2.23 & -6.24 & $\begin{array}{l}-6.5 \\
\end{array}$ & $\begin{array}{l}-7.66 \\
.187\end{array}$ & -18.17 & 433.9 & 0.61 & 0.66 & 0.20 & 3.68 & 0.28 & 1.60 & 2.18 & 7.94 \\
\hline & $\begin{array}{l}6 \text { After } 1989 \\
7 \text { Before } 1950\end{array}$ & $\begin{array}{r}196.6 \\
165.3\end{array}$ & $\begin{array}{l}0.50 \\
1.02\end{array}$ & $\begin{array}{l}0.61 \\
0.75\end{array}$ & $\begin{array}{r}0.32 \\
12.24 \\
\end{array}$ & $\begin{array}{r}-2.93 \\
-32.18\end{array}$ & $\begin{array}{r}-3.307 \\
-30.52 \\
\end{array}$ & $\begin{array}{r}-1.87 \\
-44.48\end{array}$ & $\begin{array}{r}-7.55 \\
-94.94\end{array}$ & $\begin{array}{l}314.0 \\
624.7\end{array}$ & $\begin{array}{l}0.46 \\
0.94\end{array}$ & $\begin{array}{l}0.59 \\
0.72\end{array}$ & $\begin{array}{l}0.27 \\
-0.14\end{array}$ & $\begin{array}{l}2.79 \\
3.37\end{array}$ & $\begin{array}{l}0.19 \\
0.22\end{array}$ & $\begin{array}{l}1.07 \\
1.22\end{array}$ & $\begin{array}{r}0.05 \\
20.48\end{array}$ & $\begin{array}{r}4.37 \\
25.15 \\
\end{array}$ \\
\hline & $\begin{array}{l}7 \text { Betore } 1950 \\
71950-1997\end{array}$ & $\begin{array}{r}1655.3 \\
3556\end{array}$ & $\begin{array}{l}1.02 \\
1.28\end{array}$ & $\begin{array}{l}0.15 \\
0.81\end{array}$ & $\begin{array}{l}12.24 \\
34.47\end{array}$ & $\begin{array}{r}-32.18 \\
-113.07\end{array}$ & $\begin{array}{l}-3.0 .52 \\
-70.39\end{array}$ & $\begin{array}{r}-44.48 \\
-101.99 \\
\end{array}$ & $\begin{array}{r}-94.94 \\
-250.98\end{array}$ & $\begin{array}{c}624.7 \\
1118.6\end{array}$ & $\begin{array}{l}0.94 \\
1.06\end{array}$ & $\begin{array}{l}0.12 \\
0.73\end{array}$ & $\begin{array}{l}-0.14 \\
0.32\end{array}$ & $\begin{array}{l}3.73 \\
9.78\end{array}$ & 0.22 & $\begin{array}{l}1.22 \\
2.57\end{array}$ & $\begin{array}{l}20.48 \\
62.28\end{array}$ & \\
\hline & $\begin{array}{l}71950-1790 \\
7 \\
7\end{array}$ & $\begin{array}{r}3550 \\
1058.5\end{array}$ & $\begin{array}{l}1.28 \\
0.72\end{array}$ & 0.72 & $\begin{array}{r}54.47 \\
5.42\end{array}$ & $\begin{array}{l}-113.07 \\
-17.25\end{array}$ & $\begin{array}{l}-10.39 \\
-17.03\end{array}$ & -10.33 & - & $\begin{array}{r}118.6 \\
436.2\end{array}$ & 0.61 & $\begin{array}{l}0.66 \\
0.66\end{array}$ & $\begin{array}{l}0.010 \\
-0.10\end{array}$ & $\begin{array}{l}9.18 \\
2.91\end{array}$ & 0.43 & 0.75 & . & $\begin{array}{l}75.41 \\
17.23\end{array}$ \\
\hline & 7 After 1989 & 551.5 & $\begin{array}{l}0.12 \\
0.50\end{array}$ & 0.61 & 0.72 & -8.61 & $\begin{array}{l}-1,0.15 \\
-9\end{array}$ & -51 & -2214 & $\begin{array}{l}3348 \\
334.8\end{array}$ & 0.46 & 0.59 & 0.05 & $\begin{array}{l}2.91 \\
263\end{array}$ & 0.12 & 0.68 & 5.04 & $\begin{array}{r}17.23 \\
8.51\end{array}$ \\
\hline & 8 Before 1950 & 166.3 & 1.02 & 0.76 & 0.65 & -2.19 & -2.36 & -2.76 & $\begin{array}{l}-6.66 \\
\text { - }\end{array}$ & 1149.8 & 0.94 & 0.72 & -0.38 & 5.07 & 0.51 & 2.88 & -5.00 & $\begin{array}{l}.01 \\
3.08\end{array}$ \\
\hline & 8 1950-1979 & 806.5 & 1.28 & 0.81 & 4.08 & -16.31 & -11.3 & -9.17 & -32.7 & 3125.4 & 1.06 & 0.73 & -0.38 & 18.27 & 1.46 & 8.30 & -13.70 & 13.96 \\
\hline & 8 1980-1989 & 189.9 & 0.72 & 0.72 & 0.83 & -2.03 & -2.13 & -1.29 & -4.62 & 1130.8 & 0.61 & 0.66 & -0.50 & 8.44 & 0.46 & 2.58 & -7.95 & 3.02 \\
\hline & 8 After 1989 & 585.4 & 0.66 & 0.68 & 2.54 & -5.27 & -6.3 & -3.14 & -12.17 & 1690.3 & 0.59 & 0.65 & -0.99 & 13.53 & 0.68 & 3.83 & -6.60 & 10.44 \\
\hline & 9 Before 1950 & 114.1 & 0.55 & 0.67 & 0.04 & -0.11 & -0.11 & -0.13 & -0.31 & 67.2 & 0.55 & 0.65 & -0.05 & 0.75 & 0.13 & 0.76 & 4.98 & 6.57 \\
\hline & $\begin{array}{l}91950-1979 \\
9 \\
\end{array}$ & $\begin{array}{l}924.1 \\
8038\end{array}$ & $\begin{array}{l}0.72 \\
128\end{array}$ & 0.72 & 0.41 & $\begin{array}{l}-1.18 \\
-0.57\end{array}$ & $\begin{array}{l}-0.74 \\
-0.38\end{array}$ & $\begin{array}{r}-0.35 \\
-0.8\end{array}$ & -1.86 & 1274.8 & 0.61 & 0.66 & 0.91 & 17.12 & 2.30 & $\begin{array}{l}13.05 \\
\end{array}$ & 16.16 & 49.54 \\
\hline & $\begin{array}{l}91980-1989 \\
9 \text { After 1989 }\end{array}$ & $\begin{array}{l}803.8 \\
185.7\end{array}$ & $\begin{array}{l}1.28 \\
1.13\end{array}$ & $\begin{array}{l}0.81 \\
0.77\end{array}$ & $\begin{array}{l}0.23 \\
0.06\end{array}$ & $\begin{array}{l}-0.57 \\
-0.13\end{array}$ & $\begin{array}{l}-0.38 \\
-0.09\end{array}$ & $\begin{array}{l}0.08 \\
0.03\end{array}$ & $\begin{array}{l}-0.64 \\
-0.13\end{array}$ & $\begin{array}{l}929.8 \\
4410\end{array}$ & $\begin{array}{l}1.06 \\
0.98\end{array}$ & $\begin{array}{l}0.73 \\
0.72\end{array}$ & $\begin{array}{l}-0.40 \\
-0.23\end{array}$ & $\begin{array}{r}11.26 \\
601\end{array}$ & $\begin{array}{l}1.28 \\
0.62\end{array}$ & $\begin{array}{l}7.28 \\
3.51\end{array}$ & $\begin{array}{l}14.58 \\
-2.23\end{array}$ & $\begin{array}{r}34.00 \\
7.69\end{array}$ \\
\hline & 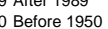 & $\begin{array}{r}185.1 \\
1110.1\end{array}$ & $\begin{array}{l}1.13 \\
1.02\end{array}$ & 0.75 & $\begin{array}{l}0.06 \\
4.29\end{array}$ & $\begin{array}{r}-0.13 \\
-14.43\end{array}$ & $\begin{array}{r}-0.09 \\
-15.54\end{array}$ & $\begin{array}{r}0.03 \\
-18.23\end{array}$ & $\begin{array}{l}-0.13 \\
-43.91\end{array}$ & $\begin{array}{l}441.0 \\
213.3\end{array}$ & $\begin{array}{l}0.98 \\
0.94\end{array}$ & $\begin{array}{l}0.12 \\
0.72\end{array}$ & $\begin{array}{l}-0.23 \\
-0.07\end{array}$ & $\begin{array}{l}6.01 \\
0.93\end{array}$ & $\begin{array}{l}0.02 \\
0.09\end{array}$ & $\begin{array}{l}3.51 \\
0.52\end{array}$ & $\begin{array}{l}-2.23 \\
2011\end{array}$ & $\begin{array}{r}7.69 \\
2158\end{array}$ \\
\hline & $\begin{array}{l}0 \\
0 \\
0\end{array}$ & 2023.3 & 128 & 0.81 & $\begin{array}{l}4 .<9 \\
10.08\end{array}$ & $\begin{array}{l}-14.43 \\
-40.29\end{array}$ & $\begin{array}{l}-10.04 \\
-27.93\end{array}$ & $\begin{array}{l}-22.65 \\
-2.65\end{array}$ & -8070 & $\begin{array}{r}13.5 .5 \\
246.5\end{array}$ & $\begin{array}{l}1.94 \\
1.06\end{array}$ & 0.73 & $\begin{array}{l}-0.03 \\
-0.03\end{array}$ & 1.44 & 0.12 & 0.65 & 37.59 & $\begin{array}{l}21.50 \\
39.78\end{array}$ \\
\hline & $01980-1989$ & 540.1 & 0.72 & 0.72 & 23 & $\begin{array}{l}-50.25 \\
-5.59\end{array}$ & -5.87 & -3.61 & -12.77 & 94.3 & 0.61 & o. & 苟 & $\begin{array}{l}1.48 \\
138\end{array}$ & 0.08 & 0.03 & $\begin{array}{l}8.19 \\
8.19\end{array}$ & $\begin{array}{r}9.18 \\
9.99\end{array}$ \\
\hline & 0 A After 198 & 259.5 & 0.50 & 0.61 & 1.24 & -2.57 & -3.08 & -1.53 & -5.94 & 251.5 & 0.46 & 0.59 & $\begin{array}{l}-0.15 \\
-0.15\end{array}$ & $\begin{array}{l}2.00 \\
2.00\end{array}$ & 0.10 & 0.56 & 2.18 & 4.69 \\
\hline & 1 Before 1950 & 62.9 & 1.02 & 0.76 & 0.15 & -0.37 & -0.37 & -0.51 & -1.1 & 975.2 & 0.94 & 0.72 & -0.57 & 6.79 & 1.02 & 5.80 & -11.31 & 1.73 \\
\hline & 1 1950-1979 & 380.6 & 1.28 & 0.81 & 1.28 & -3.15 & -1.91 & -1.05 & -4.83 & 1600.6 & 1.06 & 0.73 & -0.87 & 17.56 & 1.70 & 9.62 & -17.87 & 10.14 \\
\hline & 1 1980-1 & 104.9 & 0.72 & 0.72 & 0.31 & -0.72 & -0.5 & -0.17 & -1.08 & 7000.7 & 0.61 & 0.66 & 00 & 68 & 52 & 3.52 & -7.48 & 2.34 \\
\hline & 1 After 1989 & $\begin{array}{r}23.8 \\
\end{array}$ & 0.66 & 0.68 & 0.08 & -0.17 & -0.13 & $\begin{array}{l}-0.01 \\
\end{array}$ & $\begin{array}{r}-0.23 \\
\end{array}$ & 643.7 & 0.59 & 0.65 & 0.24 & 5.71 & 0.57 & 3.22 & -9.40 & 0.35 \\
\hline & $\begin{array}{l}2 \text { Before } 1950 \\
2\end{array}$ & $\begin{array}{l}1449.4 \\
32681\end{array}$ & $\begin{array}{l}1.02 \\
1.28\end{array}$ & $\begin{array}{l}0.76 \\
0.81\end{array}$ & $\begin{array}{l}5.2 \\
17\end{array}$ & $\begin{array}{l}-12.34 \\
-427272\end{array}$ & $\begin{array}{l}-13.65 \\
-28.18\end{array}$ & $\begin{array}{l}-18.92 \\
-21.88\end{array}$ & $\begin{array}{l}-39.71 \\
-75.78\end{array}$ & $\begin{array}{l}1266.9 \\
20153\end{array}$ & 0.94 & $\begin{array}{l}0.72 \\
0.73\end{array}$ & 0.45 & $\begin{array}{r}7.61 \\
18.03\end{array}$ & $\begin{array}{l}1.32 \\
2.22\end{array}$ & $\begin{array}{r}7.50 \\
12.60\end{array}$ & $\begin{array}{l}25.96 \\
61.81\end{array}$ & $\begin{array}{l}42.85 \\
0770\end{array}$ \\
\hline & $\begin{array}{r}\begin{array}{r}1950-1979 \\
2 \\
2980-1989\end{array}\end{array}$ & $\begin{array}{l}3268.1 \\
1424.8\end{array}$ & $\begin{array}{l}1.28 \\
1.28\end{array}$ & $\begin{array}{l}0.81 \\
0.81\end{array}$ & $\begin{array}{l}17 \\
6.05\end{array}$ & 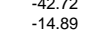 & $\begin{array}{l}-28.18 \\
-11.29 \\
-\end{array}$ & $\begin{array}{l}-21.88 \\
-4.36\end{array}$ & $\begin{array}{l}-75.78 \\
-24.49\end{array}$ & $\begin{array}{r}2015.3 \\
704.7\end{array}$ & $\begin{array}{l}1.06 \\
1.06\end{array}$ & $\begin{array}{l}0.73 \\
0.73\end{array}$ & $\begin{array}{l}2.63 \\
0.98\end{array}$ & $\begin{array}{r}18.03 \\
5.14\end{array}$ & $\begin{array}{l}2.22 \\
0.66\end{array}$ & $\begin{array}{r}12.60 \\
3.76\end{array}$ & $\begin{array}{l}61.81 \\
26.13\end{array}$ & $\begin{array}{l}97.29 \\
36.67\end{array}$ \\
\hline & 2 After 1989 & 427.5 & 1.13 & & 2.11 & -4.83 & -3.84 & -1.46 & -802 & 681.7 & 0.98 & 0.72 & 115 & 5.49 & 0.69 & 390 & -0.46 & 1078 \\
\hline & 3 Beforo e 950 & 103.5 & 102 & 0.76 & 0.25 & -06 & -0.59 & -0.83 & -177 & 4661 & 0.94 & 0.72 & -029 & 313 & 0.48 & 272 & -2.97 & $\begin{array}{l}3.107 \\
307\end{array}$ \\
\hline & 3 1950-1979 & 346.9 & 1.28 & & 1.17 & -2.87 & -1.75 & -0.95 & -4.4 & 1816.0 & 1.06 & 0.73 & -0.99 & 19.92 & 1.92 & 10.90 & -22.92 & 8.84 \\
\hline & 3 1980-1989 & 180.2 & 1.28 & 0.81 & 0.54 & -1.25 & -0.87 & -0.3 & -1.88 & 516.6 & 1.06 & 0.73 & 00 & 4.13 & 46 & 2.61 & -2.72 & 4.47 \\
\hline & 4 Before 1950 & 383.6 & 0.55 & 0.67 & 3.06 & -6.65 & -5.69 & -12.54 & -21.82 & 270.9 & 0.55 & 0.65 & 0.00 & 0.22 & 0.00 & 0.02 & 0.72 & 0.96 \\
\hline & 4 1950-1979 & 586.3 & 0.72 & 0.72 & 4.56 & -11.93 & -6.92 & -9.78 & -24.07 & 392.6 & 0.61 & 0.66 & 0.02 & 0.24 & 0.01 & 0.03 & 0.51 & 0.80 \\
\hline & 4000 & 142.7 & 0.72 & 0.72 & 1.54 & -2.92 & -2.44 & -2.42 & -6.24 & 1.9 & 年 & 0.66 & 00 & 0.01 & 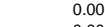 & 10 & 13 & 0.14 \\
\hline & 4 After 1989 & $\begin{array}{r}94.1 \\
2026\end{array}$ & 0.50 & 0.61 & 0.58 & $\begin{array}{r}-1.83 \\
-34\end{array}$ & $\begin{array}{r}-1.55 \\
-2.91\end{array}$ & -1.32 & $\begin{array}{r}-4.12 \\
-11.16\end{array}$ & $\begin{array}{r}51.2 \\
3361\end{array}$ & 0.46 & 0.59 & 0.01 & 0.04 & 0.00 & 0.00 & 0.08 & 0.13 \\
\hline & $\begin{array}{l}5 \text { Before } 1950 \\
5 \text { 51950-1970 }\end{array}$ & $\begin{array}{l}202.6 \\
5351\end{array}$ & $\begin{array}{l}1.02 \\
1.28\end{array}$ & $\begin{array}{l}0.75 \\
0.81\end{array}$ & $\begin{array}{l}1.56 \\
3.84\end{array}$ & $\begin{array}{r}-3.4 \\
-10.05\end{array}$ & $\begin{array}{r}-2.91 \\
-5.83\end{array}$ & $\begin{array}{l}-6.41 \\
-8.22 \\
\end{array}$ & -11.16 & $\begin{array}{l}326.1 \\
6260\end{array}$ & 0.94 & 0.72 & 0.00 & $\begin{array}{l}0.31 \\
0.39\end{array}$ & 0.01 & $\begin{array}{l}0.04 \\
0.05\end{array}$ & 0.24 & 0.59 \\
\hline & 5 1980-1989 & 34.6 & $\begin{array}{l}1.78 \\
0.72\end{array}$ & 0.72 & $\begin{array}{l}.084 \\
0.32\end{array}$ & -0.61 & $\begin{array}{l}-0.03 \\
-0.51\end{array}$ & $\begin{array}{l}-0.24 \\
-0.5\end{array}$ & - & 211.0 & 0.61 & 0.66 & 0.00 & 0.11 & 0.00 & 0.00 & $\begin{array}{l}0.44 \\
-0.09\end{array}$ & 0.02 \\
\hline & 5 After 1989 & 75.8 & 0.50 & 0.61 & 0.39 & -124 & -105 & -0.89 & -279 & 5756 & 0.4 & 0.59 & 0.014 & & 0.01 & 0.06 & -108 & 0.025 \\
\hline & 6 Before 190 & 704 & 102 & 0.01 & 0.5 & -0.91 & -0.74 & -159 & -274 & 64 & 0. & 0.072 & 0 & 0.08 & 0.00 & 0.01 & 0.21 & 0.30 \\
\hline & 6 1950-1979 & 335.5 & 1.28 & 0.81 & 2.26 & -4.73 & -2.67 & -3.33 & -8.47 & 181.7 & 1.0 & & & 0. & 00 & 0.02 & 0.91 & $\begin{array}{l}0.21 \\
1.21\end{array}$ \\
\hline & 6 1980-1989 & 74.3 & 0.72 & 0.72 & 0.39 & -0.67 & -0.67 & -0.51 & -1.46 & 0.0 & 0.61 & 0.66 & 0.00 & 0.00 & 00 & 0.00 & 0.31 & 0.31 \\
\hline & 6 After 1989 & 28.5 & 0.50 & 0.61 & 0.1 & -0.26 & -0.28 & -0.22 & -0.66 & 13.0 & 0.46 & 0.59 & 01 & 0.04 & 0 & 01 & 0.14 & 0.19 \\
\hline & 7 Before 1950 & 115.3 & 1.02 & 0.75 & .24 & -0.44 & 34 & 年 & -1.28 & 54.7 & 0.94 & 72 & 99 & 0.40 & 4 & 5 & 71 & 1.49 \\
\hline & 7 1950-1979 & 482.8 & 1.28 & 0.81 & 1.18 & -2.03 & -1.17 & -0.93 & -2.95 & 814.4 & 1.06 & 0.73 & 66 & 5.07 & 44 & 2.47 & 1.54 & 11.18 \\
\hline & 7 1980-1989 & 100.3 & 0.72 & 0.72 & 0.17 & $\begin{array}{r}-0.25 \\
-0.969\end{array}$ & $\begin{array}{r}-0.25 \\
-0.253\end{array}$ & $\begin{array}{r}-0.1 \\
-29.92\end{array}$ & $\begin{array}{r}-0.43 \\
-70\end{array}$ & $\begin{array}{l}179.8 \\
4327\end{array}$ & 0.61 & $\begin{array}{l}0.66 \\
0.65\end{array}$ & 0.46 & 1.38 & 0.16 & 0.93 & 0.35 & 3.28 \\
\hline & $\begin{array}{l}8 \text { Before } 1950 \\
81950-1950\end{array}$ & $\begin{array}{l}997.4 \\
966.9\end{array}$ & $\begin{array}{l}0.55 \\
0.72\end{array}$ & $\begin{array}{l}0.67 \\
0.72\end{array}$ & $\begin{array}{r}4.42 \\
3.6\end{array}$ & $\begin{array}{l}-16.96 \\
-23.37\end{array}$ & $\begin{array}{r}-28.53 \\
-22\end{array}$ & $\begin{array}{l}-29.92 \\
-17.99 \\
\end{array}$ & $\begin{array}{l}-70.99 \\
-59.76\end{array}$ & $\begin{array}{c}432.7 \\
1214.8\end{array}$ & $\begin{array}{l}0.55 \\
0.61\end{array}$ & $\begin{array}{l}0.65 \\
0.66\end{array}$ & $\begin{array}{l}-0.01 \\
-0.01\end{array}$ & 0.10 & $\begin{array}{l}0.00 \\
0.00\end{array}$ & $\begin{array}{l}0.00 \\
0.02\end{array}$ & 0.59 & 0.69 \\
\hline & $\begin{array}{l}81950-1979 \\
8898-1989\end{array}$ & $\begin{array}{l}960.9 \\
531.7\end{array}$ & $\begin{array}{l}0.72 \\
0.72\end{array}$ & $\begin{array}{l}0.12 \\
0.72\end{array}$ & $\begin{array}{r}3.6 \\
3.08\end{array}$ & $\begin{array}{l}-23.37 \\
-1382\end{array}$ & $\begin{array}{l}-22 \\
-944\end{array}$ & -17.99 & $\begin{array}{l}-59.16 \\
-22.78\end{array}$ & $\begin{array}{r}1211.8 \\
308.3\end{array}$ & 0.6 & 0.66 & .01 & 0.32 & 0.00 & 0.02 & 0.28 & $\begin{array}{l}0.01 \\
0.37\end{array}$ \\
\hline & 8 & 年 & 0.50 & 061 & 然 & 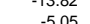 & -365 & $\begin{array}{l}-2.38 \\
-0.38\end{array}$ & 909 & $\begin{array}{l}3080.3 \\
3\end{array}$ & 04 & 0.59 & 0. & 0.15 & 000 & 0.00 & -0.06 & 0.32 \\
\hline & 9 Befo & 690 & 1.02 & 0.76 & 7 & -12.44 & -12.43 & -18.32 & -36.19 & 494.2 & 0. & 0.72 & 1 & 0.03 & 0.00 & 0.00 & 0.11 & 0.13 \\
\hline & 9 1950-1979 & 1642.4 & 1.28 & 0.81 & 15.69 & -30.44 & -19.28 & -25.11 & -59.14 & 1537.4 & 1. & & 22 & 0. & 50 & 0.00 & 0.54 & 0.83 \\
\hline & 9198 & 482.2 & 0.72 & 0.72 & 6.65 & -6.69 & -4.85 & -5.04 & -9.93 & 284.1 & 0.61 & 0.66 & 0.00 & 0.09 & 50 & 0.01 & 0.16 & 0.25 \\
\hline & 9 After 1989 & 75.9 & 0.66 & 0.68 & 1.05 & -0.95 & -0.77 & -0.53 & -1.2 & 431.3 & 0.59 & 0.65 & .00 & 0.16 & 0.00 & 0.00 & -0.13 & 0.03 \\
\hline & 0 Before 1950 & 592 & 1.02 & 0.76 & 2.91 & -4.67 & -4.01 & -7.48 & -13.25 & 927.0 & 0.94 & 0.72 & 17 & 0.70 & Ju & 16 & 89 & 1.23 \\
\hline & 0 & 1961.1 & 1.28 & 0.81 & 11.13 & -18.78 & -10.39 & -15.95 & -33.99 & 2110.2 & 1.06 & 0.73 & -0.56 & 2.40 & -0.13 & -0.72 & 3.37 & 4.36 \\
\hline & 0 & $\begin{aligned} 283.4 \\
5.5\end{aligned}$ & 0.72 & 0.72 & 2.07 & $\begin{array}{l}-1.85 \\
-04\end{array}$ & $\begin{array}{r}-1.23 \\
-0.3\end{array}$ & $\begin{array}{l}-1.03 \\
-0.19\end{array}$ & $\begin{array}{r}-2.04 \\
-0.38\end{array}$ & $\begin{array}{l}287.4 \\
5529\end{array}$ & $\begin{array}{l}0.61 \\
0.59\end{array}$ & $\begin{array}{l}0.66 \\
0.65\end{array}$ & -0.07 & 0.55 & -0.02 & -0.11 & 0.43 & 0.78 \\
\hline & 0 After 1989 & & Window & roperties & 0.51 & otal Building & Cooling Load & $\frac{0.19}{S(T \text { Trillion } B}$ & $T U / y r)=0.30$ & & $\frac{0.59}{\text { Window }}$ & perties & & $\frac{.05}{\text { Total B }}$ & illding Cooling & $\frac{-0.11}{\text { Fillion } \mathrm{B}}$ & & \\
\hline Totals & IAverages & $\begin{array}{l}\text { Number of Buildings } \\
\text { (Thesusass }\end{array}$ & \begin{tabular}{|l|l}
$u$ \\
$u$
\end{tabular} & SHGC & \begin{tabular}{|c|} 
Window \\
solor
\end{tabular} & \begin{tabular}{|l|} 
Window \\
Sond
\end{tabular} & Infiltration & Other & Total Loads & Number of Buildings & \begin{tabular}{|l|l|} 
U Factor \\
\end{tabular} & SHGC & Window & \begin{tabular}{|l|l} 
Window \\
\end{tabular} & Window & \begin{tabular}{|l|} 
Non-Window \\
\end{tabular} & Other & Total \\
\hline & & Thousands, 1993) & 0.85 & 0.73 & & $\frac{- \text { Cond } 1}{-996.96}$ & -1039.49 & & & (Thousands, 2001) & & & & $\frac{\text { Cond }}{303.66}$ & & ffiltration & $\frac{\text { Loads }}{30727}$ & o.oads \\
\hline $\begin{array}{l}\text { Percentag } \\
\text { Percen }\end{array}$ & e of Total Load & & & & $-11 \%$ & $34 \%$ & $35 \%$ & $40 \%$ & $100 \%$ & & & & $0 \%$ & $39 \%$ & $3 \%$ & $\begin{array}{l}49 \% \\
19 \%\end{array}$ & $39 \%$ & $100 \%$ \\
\hline & Windows 15 & $\%$ of total infiltration & $\begin{array}{l}\text { Window } \\
\text { Window? }\end{array}$ & $\begin{array}{l}\text { otal } \\
\text { of Total }\end{array}$ & $\begin{array}{r}-830.08 \\
28 \%\end{array}$ & Trillion BT & & & & & $\begin{array}{l}\text { Window } \\
\text { Window } \\
\text { Total Qua } \\
\text { Total Qua }\end{array}$ & $\begin{array}{l}\text { of Total } \\
\text { s Cool } \\
\text { s Window }\end{array}$ & & $\begin{array}{c}333.08 \\
42 \% \\
2.41 \\
1.02\end{array}$ & $\begin{array}{l}\text { rillion BTU Lo } \\
\text { Zuads } \\
\text { Zuads }\end{array}$ & & & \\
\hline
\end{tabular}




\section{Appendix E - Complete Commercial Results}

Large and Small Office Buildings

\begin{tabular}{|c|c|c|c|c|c|c|c|c|c|c|c|c|c|c|c|c|c|c|c|c|c|}
\hline \multirow[b]{2}{*}{ Building Type } & \multirow[b]{2}{*}{ Climate Zone } & \multirow[b]{2}{*}{ Vintage } & \multirow[b]{2}{*}{$\begin{array}{c}\text { Space } \\
\text { Condititoning } \\
\text { Mode }\end{array}$} & \multicolumn{8}{|c|}{\begin{tabular}{l|l}
\multicolumn{2}{|c|}{1991 Properties Estimated by Huang and Franconi (1999) } \\
Window Properties & Building HVAC Load Intensity (kBtulftityr) \\
W
\end{tabular}} & \multirow{2}{*}{$\begin{array}{l}\text { System Efficiency } \\
\text { Factor } \\
\text { (Primary kBtu } \\
\text { Energy Consumption } \\
\text { / kBtu Load) }\end{array}$} & \multicolumn{9}{|c|}{$\begin{array}{l}1999 \text { Updated Window Stock Estimates (Apte and Arasteh, 2006) } \\
\text { Window Properties } \\
\text { Total Building Energy Consumption (Trillion BTU/yr) }\end{array}$} \\
\hline & & & & $\begin{array}{c}\text { Conditioned } \\
\text { Area, } \\
\text { Million Square } \\
\text { Feet }\end{array}$ & U Factor & SHGC & $\begin{array}{c}\text { Window } \\
\text { Solar }\end{array}$ & $\begin{array}{l}\text { Window } \\
\text { Cond }\end{array}$ & Infiltration & $\begin{array}{l}\text { Other } \\
\text { Loads }\end{array}$ & $\begin{array}{l}\text { Total } \\
\text { Loads }\end{array}$ & & $\begin{array}{c}\text { Conditioned } \\
\text { Area, } \\
\text { Million Square } \\
\text { Feet }\end{array}$ & U Factor & SHGC & Window Solar & $\begin{array}{l}\text { Window } \\
\text { Cond }\end{array}$ & $\begin{array}{c}\text { Window } \\
\text { Infiltration }\end{array}$ & $\begin{array}{c}\text { Non-Window } \\
\text { Infiltration }\end{array}$ & Other Loads & Total Loads \\
\hline Large Office & Minneapolis & New & heat & 95.1 & 0.58 & 0.60 & 4.5 & -11.9 & -1.5 & -0.5 & -9.4 & 4.76 & 150.16 & 0.75 & 0.66 & $-1.11 E+04$ & $3.5 E+03$ & $-1.6 \mathrm{E}+02$ & $-9.1 \mathrm{E}+02$ & $-3.6 \mathrm{E}+02$ & $-8.81 E+03$ \\
\hline Large Office & Minneapolis & New & cool & 76.6 & 0.58 & 0.60 & 15.4 & -5.2 & -2 & 17.1 & 25.3 & 1.16 & 139.45 & 0.75 & 0.66 & $-1.1 \mathrm{E}+03$ & $2.7 E+03$ & $-4.9 \mathrm{E}+01$ & $-2.8 \mathrm{E}+02$ & $2.8 \mathrm{E}+03$ & $4.11 E+03$ \\
\hline $\begin{array}{l}\text { Large Office } \\
\text { Large Office }\end{array}$ & $\begin{array}{l}\text { Chicago } \\
\text { Chicago }\end{array}$ & New & heat & $\begin{array}{l}705 \\
6576\end{array}$ & 0.58 & $\begin{array}{l}0.60 \\
0.60\end{array}$ & $\begin{array}{l}3.8 \\
16.3\end{array}$ & $\begin{array}{l}-8.7 \\
-5\end{array}$ & -1.4 & $\begin{array}{l}0.1 \\
184\end{array}$ & -6.2 & $\begin{array}{l}5.56 \\
1.22\end{array}$ & $\begin{array}{l}1,068.46 \\
1014.30\end{array}$ & 0.75 & 0.66 & $\begin{array}{l}-6.6 \mathrm{E}+04 \\
-7.9 E+03\end{array}$ & $\begin{array}{l}2.5 \mathrm{E}+04 \\
2 .+24\end{array}$ & $-1.2 \mathrm{E}+03$ & $-7.1 \mathrm{E}+03$ & $5.9 \mathrm{E}+02$ & $-4.91 E+04$ \\
\hline Large Ofice & $\begin{array}{l}\text { Cnicago } \\
\text { Washington }\end{array}$ & New & cool & $\begin{array}{l}651.6 \\
556.4\end{array}$ & 0.59 & $\begin{array}{l}0.60 \\
0.61\end{array}$ & 16.3 & $\begin{array}{ccc}-5 \\
-5\end{array}$ & -1.7 & 10.4 & 28 & 1.22 & $1,01.30$ & 0.075 & 0.06 & $-9.9 E+03$ & $\begin{array}{l}2.2 E+04 \\
1.26+04\end{array}$ & $\begin{array}{l}-3.2 E+02 \\
-55+02\end{array}$ & 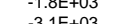 & 2.3E+04 & $\begin{array}{l}3.49 E+04 \\
3.34 E+10\end{array}$ \\
\hline Large Office & Washington & New & 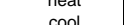 & $\begin{array}{l}530.4 \\
552\end{array}$ & 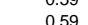 & $\begin{array}{l}0.61 \\
0.61\end{array}$ & ${ }^{2}$ & $\begin{array}{l}-4.6 \\
-49\end{array}$ & $\begin{array}{l}-0.5 \\
-16\end{array}$ & 2.1 & 年 & $\begin{array}{lll}0.33 \\
133\end{array}$ & $\begin{array}{l}8.34 \\
8421\end{array}$ & 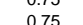 & 0.060 & 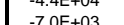 & 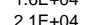 & 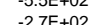 & 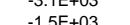 & 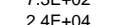 & $\begin{array}{l}-3.14 \mathrm{E}+04 \\
3.63 \mathrm{E}+04\end{array}$ \\
\hline Large Office & Los Angeles & New & heat & 6863 & 0.00 & $\begin{array}{lll}0.01 & \end{array}$ & 01 & -02 & 0 & 0 & -01 & 100.00 & 92304 & 0.75 & 0.06 & $-23 E+4$ & 9 $9 \mathrm{E}+03$ & $00 \mathrm{E}+00$ & $0.0 E+00$ & $0.0 E+00$ & $\begin{array}{l}3.63 E+04 \\
-1.33 E+04\end{array}$ \\
\hline Large Office & $\begin{array}{l}\text { Los Angeles } \\
\text { Los }\end{array}$ & New & cool & 701.9 & 0.60 & $\begin{array}{l}0.02 \\
0.62\end{array}$ & 31.5 & $\begin{array}{l}-0.2 \\
-10.2\end{array}$ & -1.3 & 25 & 45 & 1.33 & 925.16 & 0.75 & 0.66 & $-1.6 \mathrm{E}+04$ & $4.2 \mathrm{E}+04$ & $-2.4 \mathrm{E}+02$ & $-1.4 \mathrm{E}+03$ & $3.1 \mathrm{E}+04$ & $\begin{array}{l}-1.33+04 \\
550 E+04\end{array}$ \\
\hline Large Office & Houston & New & heat & 548.1 & 0.60 & 0.62 & 0.5 & -1 & -0.1 & 0.2 & -0.4 & 25.00 & $\begin{array}{l}451.33 \\
451.33\end{array}$ & 0.75 & 0.66 & $-1.4 E+04$ & $\begin{array}{l}4.2 \mathrm{~L}+04 \\
6.0 \mathrm{E}+03\end{array}$ & $-1.7 \mathrm{E}+02$ & $\begin{array}{l}-1.4 \mathrm{E}+03 \\
-9.6 \mathrm{E}+02\end{array}$ & $\begin{array}{l}2.3 \mathrm{E}+03 \\
2.1503\end{array}$ & $\begin{array}{l}5.00 \mathrm{E}+04 \\
-6.98 \mathrm{E}+03\end{array}$ \\
\hline $\begin{array}{l}\text { Large Office } \\
\text { Le }\end{array}$ & Houston & New & $\begin{array}{l}\text { cool } \\
\text { col }\end{array}$ & 548.7 & 0.60 & $\begin{array}{l}0.62 \\
0.62\end{array}$ & 24.8 & $\begin{array}{l}-5.3 \\
-5.3\end{array}$ & -1.4 & 26.4 & 44.5 & $\begin{array}{l}1.43 \\
1.43\end{array}$ & 499.24 & 0.75 & 0.66 & $-4.7 \mathrm{E}+03$ & $1.9 \mathrm{E}+04$ & $-1.5 \mathrm{E}+02$ & $-8.5 \mathrm{E}+02$ & $1.9 \mathrm{E}+04$ & $3.20 \mathrm{E}+04$ \\
\hline Large Office & Minneapolis & Old & heat & 239.4 & 0.69 & 0.70 & 4.9 & -12.2 & -1.5 & -1.8 & -10.6 & 4.17 & 304.38 & 0.75 & 0.66 & $-1.7 E+04$ & $5.9 E+03$ & $-2.9 E+02$ & $-1.6 \mathrm{E}+03$ & $-2.3 \mathrm{E}+03$ & $-1.50 E+04$ \\
\hline Lar & Minneapolis & Old & cool & $\begin{array}{l}185.4 \\
185.4\end{array}$ & 0.69 & 0.0 & 15.9 & -4.8 & -24 & 217 & 304 & 357 & 250.74 & 0.75 & 0.66 & $-4 \mathrm{E}+03$ & $1.4 \mathrm{E}+04$ & $-32 E+02$ & $-18 \mathrm{E}+03$ & $19 \mathrm{~F}+04$ & $261=+04$ \\
\hline Large Office & Chicago & Old & heat & 1621.5 & 0.69 & 0.70 & 4 & -8.9 & -1.4 & -0.7 & -7 & 5.26 & 1.065 .44 & 0.75 & 0.66 & $\begin{array}{l}-5.4 \mathrm{E}+04 \\
\end{array}$ & $2.1 E+04$ & $-1.2 E+03$ & 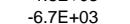 & $\begin{array}{r}1.9 E+04 \\
-3.9 E+03\end{array}$ & $\begin{array}{l}2.01 \mathrm{~L}+04 \\
-4.44 E+04\end{array}$ \\
\hline Large Office & Chicago & Old & $\begin{array}{l}\text { cool } \\
\text { coul }\end{array}$ & $\begin{array}{l}1021.5 \\
1360.6\end{array}$ & 0.69 & 0.70 & $\begin{array}{c}4 \\
16.9\end{array}$ & $\begin{array}{l}-8.9 \\
-4.8\end{array}$ & $\begin{array}{l}-1.4 \\
-2.1\end{array}$ & $\begin{array}{l}-0.1 \\
23.5\end{array}$ & 33.5 & $\begin{array}{l}3.20 \\
3.13\end{array}$ & $\begin{array}{r}1,005.44 \\
927.96\end{array}$ & 0.75 & $\begin{array}{l}0.60 \\
0.66\end{array}$ & $\begin{array}{l}-5.4 \mathrm{E}+04 \\
-1.5 \mathrm{E}+04\end{array}$ & $\begin{array}{l}2.6 \mathrm{E}+04 \\
4.64\end{array}$ & $-9.1 \mathrm{E}+02$ & $-5.2 \mathrm{E}+03$ & $\begin{array}{l}-3.9 \mathrm{E}+03 \\
6.8 \mathrm{E}+04\end{array}$ & $\begin{array}{l}-4.44 \mathrm{EE}+04 \\
9.35+04\end{array}$ \\
\hline Large Office & Washington & Old & heat & 1745.3 & 0.71 & 0.68 & 1.9 & -4.6 & -0.5 & -0.3 & -3.5 & 8.33 & $1,556.73$ & 0.75 & 0.66 & $-6.3 E+04$ & $2.4 \mathrm{E}+04$ & $-9.7 E+02$ & $-5.5 E+03$ & $-3.9 \mathrm{E}+03$ & $-4.99 \mathrm{E}+04$ \\
\hline Large Office & Washington & Old & cool & 1761.8 & 0.71 & 0.68 & 17.1 & -4.6 & -1.8 & 26.4 & 37.1 & 2.86 & $1,440.47$ & 0.75 & 0.66 & $-2.0 \mathrm{E}+04$ & $6.8 \mathrm{E}+04$ & $-1.1 \mathrm{E}+03$ & $-6.3 \mathrm{E}+03$ & $1.1 \mathrm{E}+05$ & $1.49 \mathrm{E}+05$ \\
\hline Large Office & Los Angeles & Old & heat & 996.2 & 72 & 0.67 & 0.1 & -0.2 & 0 & 0 & -0.1 & 100.00 & 771.60 & 0.75 & 0.66 & $-1.6 \mathrm{E}+04$ & $7.6 \mathrm{E}+03$ & $0.0 E+00$ & $0.0 E+00$ & $0.0 \mathrm{E}+00$ & $-8.49 E+03$ \\
\hline Large Office & Los Angeles & Old & cool & 983.2 & 0.72 & 0.67 & 26.2 & -8.5 & -1.3 & 31 & & 2.27 & 785.41 & 0.75 & 0.66 & $-1.6 E+04$ & 4.6E+04 & $-3.5 \mathrm{E}+02$ & $-2.0 E+03$ & $5.5 \mathrm{E}+04$ & $8.33 E+04$ \\
\hline $\begin{array}{l}\text { Large Office } \\
\text { arge Office }\end{array}$ & $\begin{array}{l}\text { Houston } \\
\text { Houston }\end{array}$ & Old & heat & 428.8 & 0.72 & 0.67 & 0.5 & -0.9 & -0.1 & 0 & -0.5 & 33.33 & 427.46 & 0.75 & 0.6 & $-1.3 \mathrm{E}+04$ & $7.0 \mathrm{E}+03$ & $-2.1 \mathrm{E}+02$ & $-1.2 \mathrm{E}+03$ & $0.0 \mathrm{E}+00$ & $-7.77 \mathrm{E}+03$ \\
\hline Large Unice & Houston & & cool & 324.7 & 0.72 & 0.67 & 20.5 & -4.4 & -1.5 & 33 & 47.6 & 2.13 & 507.98 & 0.75 & 0.66 & $-5.0 E+03$ & $2.2 E+04$ & $-2.4 E+02$ & $-1.4 E+03$ & $3.6 \mathrm{E}+04$ & $5.09 \mathrm{E}+04$ \\
\hline Small Office & Minneapolis & New & heat & 30.8 & 0.50 & 0.62 & 5.9 & -10.3 & -8.2 & -10.8 & -23.4 & 1.82 & 108.73 & 0.75 & 0.66 & $-3.0 E+03$ & $1.2 \mathrm{E}+03$ & $-2.4 \mathrm{E}+02$ & $-1.4 E+03$ & $-2.1 \mathrm{E}+03$ & $-5.55 E+03$ \\
\hline Small Office & Minneapolis & New & cool & 30.6 & 50 & 0.62 & 1.0 & -1.1 & -1 & 8.6 & 14 & 1.27 & 95.44 & 0.75 & 0.66 & $-2.0 \mathrm{E}+02$ & $9.7 E+02$ & $-1.8 \mathrm{E}+01$ & 02 & 1.0 & $1.69 E+03$ \\
\hline Small Office & Chicago & New & heat & 150.9 & 0.50 & 0.62 & 4.7 & -7.6 & -6.2 & -6.6 & -15.7 & 1.96 & 323.44 & 0.75 & 0.66 & $-7.2 E+03$ & $3.2 E+03$ & $-5.9 \mathrm{E}+02$ & $-3.3 \mathrm{E}+03$ & $-4.2 E+03$ & $-1.21 \mathrm{E}+04$ \\
\hline Small Office & Chicago & New & cool & 149.1 & 0.50 & 0.62 & 8.5 & -1.3 & -1.1 & 10.4 & 16.5 & 1.35 & 316.85 & 0.75 & 0.66 & $-8.3 E+02$ & $3.9 \mathrm{E}+03$ & $-7.1 \mathrm{E}+01$ & $-4.0 E+02$ & $4.5 \mathrm{E}+03$ & $7.04 E+03$ \\
\hline Small Office & Washington & New & heat & 214.3 & 0.56 & 0.63 & 3.7 & -5.5 & -5.2 & -5.6 & -12.6 & 1.85 & 359.68 & 0.75 & 0.66 & $-4.9 E+03$ & $2.6 \mathrm{E}+03$ & $-5.2 E+02$ & $-2.9 E+03$ & $-3.7 E+03$ & $-9.54 \mathrm{E}+03$ \\
\hline Small Office & Washington & New & cool & 216 & 0.56 & 0.63 & 6.9 & -0.8 & -1 & 12.1 & 17.2 & 1.43 & 332.70 & 0.75 & 0.66 & $-5.1 E+02$ & $3.4 \mathrm{E}+03$ & $-7.1 \mathrm{E}+01$ & $-4.0 E+02$ & $5.8 \mathrm{E}+03$ & $8.18 \mathrm{E}+03$ \\
\hline Small O & Los Angeles & New & heat & 349.7 & & 0.65 & 0.4 & -0.4 & -0.5 & -0.3 & -0.8 & 3.85 & 551.13 & 0.75 & 0.66 & $-1.0 \mathrm{E}+03$ & $8.6 \mathrm{E}+02$ & $-1.6 \mathrm{E}+02$ & $-9.0 \mathrm{E}$ & -6.4 & $-1.84 E+03$ \\
\hline Small Office & Los Angeles & New & cool & 34 & 0.63 & 0.65 & 8.7 & -1.3 & -1.3 & 13.6 & 19.7 & 1.52 & 537.85 & 0.75 & 0.66 & $-1.3 E+03$ & $7.2 E+03$ & $-1.6 \mathrm{E}+02$ & -9.0 & 1.1. $\mathrm{E}+04$ & $1.59 \mathrm{E}+04$ \\
\hline Small Office & Houston & New & heat & 276.7 & 0.63 & 0.65 & 1.5 & -1.6 & -1.7 & -0.8 & -2.6 & 2.27 & 174.64 & 0.75 & 0.66 & $-7.5 \mathrm{E}+02$ & $6.0 \mathrm{E}+02$ & $-1.0 E+02$ & $-5.7 E+02$ & $-3.2 \mathrm{E}+02$ & $-1.14 \mathrm{E}+03$ \\
\hline Small Office & Houston & New & cool & 272.3 & 0.63 & 0.65 & 8.4 & -0.6 & -1 & 17.6 & 24.4 & 1.54 & 195.93 & 0.75 & 0.66 & $-2.1 E+02$ & $2.6 \mathrm{E}+03$ & $-4.5 \mathrm{E}+01$ & $-2.6 \mathrm{E}+02$ & $5.3 E+03$ & $7.35 \mathrm{E}+03$ \\
\hline Small of & nea & Old & heat & 31 & 0.57 & 0.69 & 7.7 & -14.6 & & -18.1 & -25 & 1.85 & 171. & 0.75 & 0.66 & $-6.1 \mathrm{E}$ & $2.4 \mathrm{E}+03$ & -3.5 & -2.0 & $-3.4 E+03$ & $-9.54 E+03$ \\
\hline $\mathrm{Sn}$ & Minr & Old & & & 0.57 & 0.69 & 13 & -2.4 & -1.4 & 10.8 & 20 & 1.69 & 151.66 & 0.75 & & $-8.1 \mathrm{E}$ & 3.2 & $-5.4 \mathrm{E}+01$ & -3.1 & & $4.81 E+03$ \\
\hline Small Office & Chicago & Old & heat & & 0.57 & 0.69 & 5.7 & -10.2 & -5.3 & -6.6 & -16.4 & 1.96 & 315.55 & 0.75 & 0.66 & $-8.3 E+03$ & 3.4 & $-4.9 \mathrm{E}+02$ & $-2.8 \mathrm{~s}>\mathrm{l}$ & $-4.1 \mathrm{E}+03$ & $-1.23 E+04$ \\
\hline Small O & & Old & & 582 & 0.57 & 0.69 & 14.6 & -2.7 & -1.5 & 12.9 & 23.3 & 1.72 & 280.28 & 0.75 & 0.66 & $-1.7 E+03$ & $6.8 \mathrm{E}+03$ & $-1.1 \mathrm{E}+02$ & $-6.2 E+02$ & $6.2 \mathrm{E}+03$ & $1.06 \mathrm{E}+04$ \\
\hline Small Office & Washin & Old & & & & 0.70 & 5.9 & -8.7 & -4. & -3 & -10 & 2.08 & 579.45 & 0.75 & 0. & -1.2 & $6.7 \mathrm{E}$ & $-7.8 \mathrm{E}+02$ & $-4.4 E+03$ & & $-1.44 E+04$ \\
\hline Small Office & Washin & Old & cool & 47 & 0.65 & 0.70 & 16.5 & -3.3 & -1.9 & 16.1 & 27.4 & 1.79 & 435.39 & 0.75 & 0.66 & $\begin{array}{l}-3.0 E+03 \\
-T_{2}\end{array}$ & 1.2E+04 & $-2.2 E+02$ & $-1.3 \mathrm{E}+03$ & $1.3 \mathrm{E}+04$ & $2.02 E+04$ \\
\hline $\mathrm{Sn}$ & Los An & Old & $\mathrm{h}$ & 59 & 0.75 & 0.71 & 0.3 & -0.4 & -0.2 & -0.2 & -0.5 & 11.11 & 53 & 0.75 & 0.66 & $-2.4 \mathrm{E}$ & 1.6 & $-1.8 \mathrm{E}+02$ & -1.0 & -1.2 & $-3.09 \mathrm{E}+03$ \\
\hline $\mathrm{si}$ & Los Ar & Old & c & 59 & 5 & 0.7 & 25 & -5.4 & -2.8 & 20 & 36. & 1.75 & 464.95 & 0.75 & 0.66 & $-4.4 \mathrm{E}$ & 1.9 & -3.4 & -1.9 & 1.6 & $2.85 E+04$ \\
\hline Small Office & Houston & Old & heat & 525.8 & 0.75 & 0.71 & 1.3 & -1.7 & -0.9 & -0.3 & -1.6 & 4.35 & 293.03 & 0.75 & 0.66 & $-2.2 E+03$ & $1.5 \mathrm{E}+03$ & $-1.7 E+02$ & $-9.7 E+02$ & $-3.8 E+02$ & $-2.17 E+03$ \\
\hline Small Office & Houston & Old & cool & 524.1 & 0.75 & 0.71 & 20 & -1.9 & -1.4 & 23.9 & 40.6 & 1.72 & 291.14 & 0.75 & 0.66 & $-9.6 \mathrm{E}+02$ & $9.3 \mathrm{E}+03$ & $-1.1 \mathrm{E}+02$ & $-6.0 \mathrm{E}+02$ & $1.2 \mathrm{E}+04$ & $1.96 \mathrm{E}+04$ \\
\hline $\begin{array}{l}\text { Large Office } \\
\text { Large Office }\end{array}$ & $\begin{array}{l}\text { Total } \\
\text { Total }\end{array}$ & $\begin{array}{l}\text { Total } \\
\text { Total }\end{array}$ & $\begin{array}{l}\text { heat } \\
\text { cool }\end{array}$ & $\begin{array}{l}7622.1 \\
7135.7\end{array}$ & & & & & & & & & $\begin{array}{l}7,592.95 \\
7,334.92\end{array}$ & & & $\begin{array}{l}-3.22 \mathrm{E}+05 \\
-9.70+04\end{array}$ & $\begin{array}{l}1.26 \mathrm{E}+05 \\
3.03 \mathrm{E}+05\end{array}$ & $\begin{array}{l}-4.77 \mathrm{E}+03 \\
-3.96 \mathrm{E}+03\end{array}$ & $\begin{array}{l}-2.70 \mathrm{E}+04 \\
-2.25+04\end{array}$ & $\begin{array}{l}-6.88 \mathrm{E}+03 \\
3.88 \mathrm{E}+05\end{array}$ & $\begin{array}{l}-2.335 \mathrm{E}+05 \\
5.65 \mathrm{E}+05\end{array}$ \\
\hline Small Office & Total & Total & heat & 3657.4 & & & & & & & & & $\begin{array}{l}3,334.92 \\
3,408.44\end{array}$ & & & $-4.81 E+04$ & $2.41 \mathrm{E}+04$ & $-3.59 E+03$ & $-2.03 E+04$ & $-2.38 \mathrm{E}+04$ & $-7.17 \mathrm{E}+04$ \\
\hline Small Office & Total & Total & cool & 3450.6 & & & & & & & & & $3,102.20$ & & & $-1.39 E+04$ & $6.82 \mathrm{E}+04$ & $-1.20 E+03$ & $-6.78 E+03$ & $7.75 E+04$ & $1.24 \mathrm{E}+05$ \\
\hline
\end{tabular}


Large and Small Retail Buildings

\begin{tabular}{|c|c|c|c|c|c|c|c|c|c|c|c|c|c|c|c|c|c|c|c|c|c|}
\hline \multirow[b]{2}{*}{ Building Type } & \multirow[b]{2}{*}{ Climate Zone } & \multirow[b]{2}{*}{ Vintage } & \multirow[b]{2}{*}{ heat } & \multicolumn{8}{|c|}{ 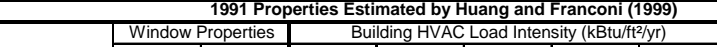 } & \multirow[b]{2}{*}{$\begin{array}{c}\text { System Efficiency } \\
\text { Factor } \\
\text { (Primary kBtu } \\
\text { Energy Consumumtion } \\
\text { / kBtu Load) }\end{array}$} & \multicolumn{9}{|c|}{1999 Updated Window Stock Estimates (Apte and Arasteh, 2006) } \\
\hline & & & & $\begin{array}{c}\text { Conditioned } \\
\text { Area, } \\
\text { Million Square } \\
\text { Feet }\end{array}$ & U Factor & SHGC & $\begin{array}{c}\text { Window } \\
\text { Solar }\end{array}$ & $\begin{array}{l}\text { Window } \\
\text { Cond }\end{array}$ & Infiltration & $\begin{array}{l}\text { Other } \\
\text { Loads }\end{array}$ & $\begin{array}{l}\text { Total } \\
\text { Loads }\end{array}$ & & $\begin{array}{c}\text { Conditioned } \\
\text { Area, } \\
\text { Million Square } \\
\text { Feet }\end{array}$ & U Factor & SHGC & Window Solar & $\begin{array}{c}\text { Total BC } \\
\text { Window } \\
\text { Cond }\end{array}$ & $\begin{array}{c}\text { ding Energy C } \\
\text { Window } \\
\text { Infiltration }\end{array}$ & $\begin{array}{c}\text { Non-Window } \\
\text { Infiltration }\end{array}$ & Other Loads & Total Loads \\
\hline Large Retail & Minneapolis & New & heat & 188.3 & 0.58 & 0.64 & 1.5 & -3.8 & -5.6 & 1.4 & -6.5 & & 91.91 & 0.75 & 0.66 & $-2.2 \mathrm{E}+03$ & $7.1 \mathrm{E}+02$ & $-3.9 \mathrm{E}+02$ & $-2.2 \mathrm{E}+03$ & $6.4 \mathrm{E}+02$ & $-3.46 \mathrm{E}+03$ \\
\hline & Minneapolis & New & cool & 177 & 0.58 & 0.64 & 4.6 & -1.6 & -1.8 & 18.2 & 19.4 & 1.39 & 76.15 & 0.75 & 0.66 & $-2.2 \mathrm{E}+02$ & $5.0 \mathrm{E}+02$ & $-2.9 \mathrm{E}+01$ & $-1.6 \mathrm{E}+02$ & $1.9 \mathrm{E}+03$ & $2.02 E+03$ \\
\hline Large Retail & Chicago & New & heat & 745.6 & 0.58 & 0.64 & 0.9 & -2.1 & -3.4 & 1.3 & -3.3 & 7.14 & 457.24 & 0.75 & 0.66 & $-8.8 \mathrm{E}+03$ & $3.0 \mathrm{E}+03$ & $-1.7 E+03$ & $-9.4 \mathrm{E}+03$ & $4.2 \mathrm{E}+03$ & $-1.26 \mathrm{E}+04$ \\
\hline Large Retail & Chicago & New & cool & 546.2 & 0.58 & 0.64 & 4.6 & -1.2 & -1.1 & 20.5 & 22.8 & 1.43 & 422.59 & 0.75 & 0.66 & $-9.3 \mathrm{E}+02$ & $2.8 \mathrm{E}+03$ & $-1.0 \mathrm{E}+02$ & $-5.6 \mathrm{E}+02$ & $1.2 \mathrm{E}+04$ & 1.36E+04 \\
\hline Large Retail & Washington & New & heat & 178.5 & 0.59 & 0.65 & 0.2 & -0.5 & -1 & 0.2 & -1.1 & 14.29 | & 481.10 & 0.75 & 0.66 & $-4.4 \mathrm{E}+03$ & $1.4 \mathrm{E}+03$ & $-1.0 \mathrm{E}+03$ & $-5.8 \mathrm{E}+03$ & $1.4 \mathrm{E}+03$ & $-8.46 \mathrm{E}+03$ \\
\hline Large Retail & Washington & New & cool & 173.6 & 0.59 & 0.65 & 4.8 & -0.7 & -0.1 & 23.1 & 27.1 & 1.52 & 466.90 & 0.75 & 0.66 & $-6.3 \mathrm{E}+02$ & $3.4 \mathrm{E}+03$ & $-1.1 E+01$ & $-6.0 \mathrm{E}+01$ & $1.6 \mathrm{E}+04$ & $1.91 \mathrm{E}+04$ \\
\hline Large Retail & Los Angeles & New & heat & 230.6 & 0.60 & 0.66 & 0 & 0 & 0 & 0 & 0 & & 784.11 & 0.75 & 0.66 & $0.0 E+00$ & $0.0 E+00$ & $0.0 E+00$ & $0.0 E+00$ & $0.0 E+00$ & $0.00 E+00$ \\
\hline Large Retail & Los Angeles & New & cool & 201.3 & 0.60 & 0.66 & 8.4 & -2.3 & -2.9 & 32.9 & 36.1 & 1.33 & 789.88 & 0.75 & 0.66 & $-3.0 \mathrm{E}+03$ & $8.8 \mathrm{E}+03$ & $-4.6 \mathrm{E}+02$ & $-2.6 \mathrm{E}+03$ & $3.5 E+04$ & 3.74E+04 \\
\hline $\begin{array}{l}\text { Large Retail } \\
\text { Large Retail }\end{array}$ & $\begin{array}{l}\text { Houston } \\
\text { Houston }\end{array}$ & $\begin{array}{l}\text { New } \\
\text { New }\end{array}$ & $\begin{array}{l}\text { heat } \\
\text { cool }\end{array}$ & $\begin{array}{l}409.4 \\
368.4\end{array}$ & $\begin{array}{l}0.60 \\
0.60\end{array}$ & $\begin{array}{l}0.66 \\
0.66\end{array}$ & $\begin{array}{l}0 \\
6.5\end{array}$ & $\begin{array}{c}0 \\
-0.9\end{array}$ & $\begin{array}{c}0 \\
-1.1\end{array}$ & $\begin{array}{c}0 \\
34.5\end{array}$ & $\begin{array}{l}0 \\
39\end{array}$ & $\begin{array}{r}100.00 \\
1.52\end{array}$ & $\begin{array}{l}568.30 \\
647.95\end{array}$ & $\begin{array}{l}0.75 \\
0.75\end{array}$ & $\begin{array}{l}0.66 \\
0.66\end{array}$ & $\begin{array}{r}0.0 \mathrm{E}+00 \\
-1.1 \mathrm{E}+03\end{array}$ & $\begin{array}{l}0.0 \mathrm{E}+00 \\
6.4 \mathrm{E}+03\end{array}$ & $\begin{array}{l}0.0 \mathrm{E}+00 \\
-1.6 \mathrm{E}+02\end{array}$ & $\begin{array}{r}0.0 \mathrm{E}+00 \\
-9.2 \mathrm{E}+02\end{array}$ & $\begin{array}{l}0.0 \mathrm{E}+00 \\
3.4 \mathrm{E}+04\end{array}$ & $\begin{array}{l}0.00 \mathrm{E} E+00 \\
3.81 \mathrm{E}+04\end{array}$ \\
\hline Large Retail & Minneapolis & Old & heat & 345.9 & 0.65 & 0.68 & 2.3 & -5.1 & -8.8 & 2.5 & -9.1 & 6.25 & 147.66 & 0.75 & 0.66 & $-5.4 E+03$ & & $-12 E+03$ & $-69 E+03$ & $23 E+03$ & \\
\hline Large $\mathrm{Re}$ & Minneapolis & Old & cool & 243 & 0.65 & 0.68 & 4.8 & -2 & -3.2 & 18.1 & 17.7 & 2.86 & 121.54 & 0.7 & 0.66 & $-8.0 \mathrm{E}+02$ & $1.6 \mathrm{E}+03$ & $-1.7 E+02$ & $-9.4 \mathrm{E}+02$ & $.3 \mathrm{E}+03$ & OFE+03 \\
\hline Large Retail & Chicago & Old & heat & 806.8 & 0.65 & 0.68 & 1.5 & -3.1 & -5.7 & 2.2 & -5.1 & 9.09 & 442.88 & 0.75 & 0.66 & $\begin{array}{l}-1.4 E+04 \\
-1.45\end{array}$ & $5.9 E+03$ & $-3.4 E+03$ & $-2.0 E+04$ & $8.9 \mathrm{E}+03$ & $-2.26 \mathrm{E}+04$ \\
\hline Large Retail & Chicago & Old & cool & 381.9 & 0.65 & 0.68 & 4.7 & -1.3 & -2 & 19.5 & 20.9 & 2.50 & 378.16 & 0.75 & 0.66 & $-1.4 \mathrm{E}+03$ & $4.3 \mathrm{E}+03$ & $-2.8 \mathrm{E}+02$ & $-1.6 \mathrm{E}+03$ & $1.8 \mathrm{E}+04$ & $1.94 \mathrm{E}+04$ \\
\hline Large Retail & Washington & Old & heat & 1162 & 0.68 & 0.68 & 0.3 & -0.8 & -1.9 & 0.7 & -1.7 & 20.00 & 480.26 & 0.75 & 0.66 & $-8.4 \mathrm{E}+03$ & $2.8 \mathrm{E}+03$ & $-2.7 \mathrm{E}+03$ & $-1.6 \mathrm{E}+04$ & $6.7 \mathrm{E}+03$ & $-1.72 \mathrm{E}+04$ \\
\hline Large Retail & Washington & Old & cool & 924.6 & 0.68 & 0.68 & 4.5 & -0.5 & -0.2 & 21.5 & 25.3 & 2.22 & 445.90 & 0.75 & 0.66 & $-5.4 \mathrm{E}+02$ & $4.3 \mathrm{E}+03$ & $-3.0 \mathrm{E}+01$ & $-1.7 \mathrm{E}+02$ & 2.1 $1 \mathrm{E}+04$ & 2.49E+04 \\
\hline Large Retail & Los Angeles & Old & heat & 752.3 & 0.72 & 0.69 & 0 & 0 & 0 & 0 & 0 & & 432.25 & 0.75 & 0.66 & $0.0 \mathrm{E}+00$ & $0.0 \mathrm{E}+00$ & $0.0 \mathrm{E}+00$ & $00 \mathrm{E}+00$ & $0.0 E+00$ & $0.00 E+00$ \\
\hline Large Retail & Los Angeles & Old & cool & 686.4 & 0.72 & 0.69 & 8.7 & -2.5 & -4.5 & 32.7 & 34.4 & 1.72 & 441.14 & 0.75 & 0.66 & $-2.0 \mathrm{E}+03$ & $6.4 \mathrm{E}+03$ & $-5.1 \mathrm{E}+02$ & $-2.9 \mathrm{E}+03$ & $2.5 E+04$ & $2.58 \mathrm{E}+04$ \\
\hline Large Retail & $\begin{array}{l}\text { Houston } \\
\text { Houston }\end{array}$ & Old & heat & 477.3 & 0.72 & $\begin{array}{l}0.69 \\
0.69 \\
\end{array}$ & 0 & 0 & -0.1 & 0 & -0.1 & 100.00 & 313.82 & 0.75 & 0.66 & $0.0 \mathrm{E}+00$ & $0.0 \mathrm{E}+00$ & $-4.7 \mathrm{E}+02$ & $-2.7 \mathrm{E}+03$ & $0.0 E+00$ & $-3.14 E+03$ \\
\hline Large Retail & Houston & Old & cool & 412.3 & 0.72 & 0.69 & 6.6 & -0.9 & -1.8 & 33.4 & 37.3 & 1.72 & 398.25 & 0.75 & 0.66 & $-6.4 \mathrm{E}+02$ & 4.4E+03 & $-1.9 \mathrm{E}+02$ & $-1.1 \mathrm{E}+03$ & $2.3 \mathrm{E}+04$ & $2.54 E+04$ \\
\hline Small Retail & Minneapolis & New & he & 71.5 & 0.58 & 0.74 & 4.3 & -11.2 & -9.4 & -13.6 & -29.9 & 1.72 & 106.89 & 0.75 & 0.66 & $-2.6 \mathrm{E}+03$ & $7.1 \mathrm{E}+02$ & $-2.6 \mathrm{E}+02$ & $-1.5 \mathrm{E}+03$ & $-2.5 E+03$ & $-6.18 E+03$ \\
\hline Small $R$ & Minneapolis & New & cool & 26.2 & 0.58 & 0.74 & 7.5 & -1.2 & -1 & 10.4 & 15.7 & 1.64 & 52.68 & 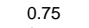 & 0.66 & -1.3 & 5.8 & -1.3 & -7.36 & $9.0 \mathrm{E}$ & $1.26 \mathrm{E}+03$ \\
\hline iil & Chicago & New & heat & 189.1 & 0.58 & 0.74 & 3.5 & -8.1 & -7.1 & -8.2 & -19.9 & 1.75 & 262.51 & 75 & 0.66 & -4.8 & $1.4 \mathrm{E}+03$ & -4.96 & -2.8 & 03 & $-1.04 E+04$ \\
\hline Small Retail & Washington & New & cool & 158.9 & 0.58 & 0.74 & 8.8 & -1.4 & -1.2 & 12.8 & 102 & 1.69 & 166.54 & 75 & 0.66 & 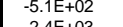 & 3 & -5.16 & & $3.6 \mathrm{E}+03$ & $4.98 \mathrm{E}+03$ \\
\hline $\begin{array}{l}\text { Small Retail } \\
\text { Small Retail }\end{array}$ & $\begin{array}{l}\text { Washington } \\
\text { Washingtono }\end{array}$ & $\begin{array}{l}\text { New } \\
\text { New }\end{array}$ & $\begin{array}{l}\text { heat } \\
\text { cool }\end{array}$ & $\begin{array}{l}331.6 \\
221.6\end{array}$ & $\begin{array}{l}0.59 \\
0.59\end{array}$ & $\begin{array}{l}0.74 \\
0.74\end{array}$ & 3.7 & $\begin{array}{l}-6.6 \\
-19\end{array}$ & -6 & -3.4 & $\begin{array}{l}-12.3 \\
236\end{array}$ & 1.69 & $\begin{array}{l}172.47 \\
150.98\end{array}$ & 0.75 & 0.66 & $-2.4 \mathrm{E}+03$ & $\begin{array}{r}9.7 \mathrm{E}+02 \\
2 . \mathrm{F}+03\end{array}$ & $-2.6 \mathrm{E}+02$ & $\begin{array}{l}-1.5 \mathrm{E}+03 \\
-11 \mathrm{~F}+0 ?\end{array}$ & $\begin{array}{l}-9.9 E+02 \\
45 E+03\end{array}$ & $\begin{array}{l}-4.22 E+03 \\
5.93 E+03\end{array}$ \\
\hline $\begin{array}{l}\text { Small Retail } \\
\text { Small Retail }\end{array}$ & $\begin{array}{l}\text { Washington } \\
\text { Los Angeles }\end{array}$ & $\begin{array}{l}\text { New } \\
\text { New }\end{array}$ & $\begin{array}{l}\text { cool } \\
\text { heat }\end{array}$ & $\begin{array}{l}2211.6 \\
2597\end{array}$ & $\begin{array}{l}0.59 \\
0.60\end{array}$ & $\begin{array}{l}0.74 \\
0.73\end{array}$ & $\begin{array}{l}10.6 \\
0.4\end{array}$ & $\begin{array}{l}-1.9 \\
-0.5\end{array}$ & $\begin{array}{l}-1.8 \\
-0.4\end{array}$ & $\begin{array}{l}16.7 \\
0\end{array}$ & $\begin{array}{l}23.6 \\
-0.5\end{array}$ & $\begin{array}{l}1.99 \\
3.45\end{array}$ & $\begin{array}{l}150.98 \\
29178\end{array}$ & $\begin{array}{l}0.15 \\
0.75\end{array}$ & 0.66 & $\begin{array}{l}-6.5 \mathrm{E}+02 \\
-63 \mathrm{~F}+02\end{array}$ & $\begin{array}{l}2.6 E+03 \\
3.6 F+02\end{array}$ & $\begin{array}{l}-7.3 E+01 \\
-6.0 E+01\end{array}$ & $\begin{array}{l}-4.1 E+02 \\
-3.4 F+02\end{array}$ & $\begin{array}{l}4.5 E+03 \\
0.0 F+00\end{array}$ & $\begin{array}{l}5.93 \mathrm{E}+03 \\
6.69 \mathrm{~F}+0 ?\end{array}$ \\
\hline Small Retail & $\begin{array}{l}\text { Los Angeles } \\
\text { Los Angeles }\end{array}$ & New & $\begin{array}{l}\text { neat } \\
\text { cool }\end{array}$ & $\begin{array}{l}187.8 \\
187.8\end{array}$ & $\begin{array}{l}0.60 \\
0.60\end{array}$ & $\begin{array}{l}0.73 \\
0.73\end{array}$ & $\begin{array}{l}0.4 \\
16.3\end{array}$ & $\begin{array}{l}-0.5 \\
-3.1 \\
-1.1\end{array}$ & $\begin{array}{l}-0.4 \\
-2.1 \\
-1\end{array}$ & 19.6 & $\begin{array}{l}-0.5 \\
30.7\end{array}$ & $\begin{array}{l}3.45 \\
1.59\end{array}$ & $\begin{array}{l}291.10 \\
299.31\end{array}$ & $\begin{array}{l}0.75 \\
0.75\end{array}$ & $\begin{array}{l}0.66 \\
0.66\end{array}$ & $\begin{array}{l}-6.3 \mathrm{E}+02 \\
-1.8 \mathrm{E}+03\end{array}$ & $\begin{array}{l}3.6 \mathrm{E}+02 \\
7.0 \mathrm{E}+03\end{array}$ & $\begin{array}{l}-6.0 E+01 \\
-1.5 E+02\end{array}$ & $\begin{array}{l}-3.4 \mathrm{E}+02 \\
-8.5 \mathrm{E}+02\end{array}$ & $\begin{array}{l}0.0 \mathrm{E}+00 \\
9.3 \mathrm{E}+03\end{array}$ & $\begin{array}{l}-6.09 E \mathrm{E}+02 \\
1.35+04\end{array}$ \\
\hline Small Retail & Houston & New & heat & 273.5 & 0.60 & 0.73 & 1.4 & -1.8 & -1.4 & -0.2 & -2 & 1.92 & 115.98 & 0.75 & 0.6 & $-5.0 \mathrm{E}$ & $2.8 \mathrm{E}$ & $-4.7 \mathrm{E}+01$ & $-2.7 \mathrm{E}$ & $-4.5 E+01$ & $-5.78 E+02$ \\
\hline Small Retail & Houston & New & cool & 192.8 & 0.60 & 0.73 & 12.6 & -0.7 & -0.9 & 23.3 & 34.3 & 1.89 & 230.71 & 0.75 & 0.66 & $-3.8 \mathrm{E}+02$ & $5.0 \mathrm{E}+03$ & $-5.9 \mathrm{E}+01$ & $-3.3 \mathrm{E}+02$ & $1.0 \mathrm{E}+04$ & $1.43 E+04$ \\
\hline & & Old & & 52 & 0.81 & 5 & 4.9 & -15.4 & -9 & -18 & -37.6 & 1.72 & 284.49 & 0.7 & 0.66 & $-7.0 t<>2$ & & $-6.6 \mathrm{~s}<-2$ & & & \\
\hline & is & Old & & & & & 8.5 & -1 & -1 & & & & 187.22 & & $0.6-8>$ & & & $-5.2 \mathrm{E}+01$ & & & $5.76 \mathrm{E}+03$ \\
\hline Sm & 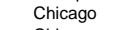 & Old & he & 1470.2 & 0.81 & 0. & 3.9 & -11.1 & -6.8 & -10 & -24.9 & 22 & 737.37 & 0. & 0.6 & $-1.3 E$ & & -1.36 & -7.3 & & $-3.13 E+04$ \\
\hline $\mathrm{Sm}$ & & ol & co & 955 & 0.81 & 75 & 10 & -1.7 & -1.2 & 14 & 21.2 & 89 & 484.38 & & 0 & & & & & $1.3 \mathrm{E}+04$ & $1.84 \mathrm{E}+04$ \\
\hline Small Retail & Washington & Old & he & 929.1 & 0.76 & 0.74 & 4.4 & -8.2 & -5.9 & -4.3 & -14 & 1.69 & 273.24 & 0.75 & 0.66 & $-3.7 E+03$ & $1.8 \mathrm{E}+03$ & $-4.1 \mathrm{E}+02$ & $-2.3 E+03$ & $-2.0 \mathrm{E}+03$ & $-6.66 \mathrm{E}+03$ \\
\hline Small Retail & Washington & Old & & 619 & 0.76 & 0.74 & 12.4 & -2.6 & -2 & 19.3 & 27.1 & 1.89 & 198.67 & 0.75 & 0.6 & $-9.6 \mathrm{E}+02$ & $4.1 \mathrm{E}+03$ & $-1.1 \mathrm{E}+02$ & $-6.4 \mathrm{E}+02$ & $7.2 \mathrm{E}+03$ & $9.65 E+03$ \\
\hline $\mathrm{Sm}$ & s & Old & he & 892.8 & 0.72 & 0.74 & 0.6 & -0.5 & -0.5 & -0.1 & -0.5 & 4.00 & 479.80 & 0.75 & $0.6-8>$ & -1.0 & $1.0 E$ & $-1.4 \mathrm{E}$ & -8.2 & $-1.9 E+02$ & $-1.12 E+03$ \\
\hline il & Los $A_{i}$ & Old & co & 569.4 & 0.72 & 0.74 & 19.2 & -3.9 & -2.7 & 23.7 & 36.3 & 1.75 & 456.64 & 0.7 & $0.6-8>$ & & $1.4 \mathrm{Y}>\mathrm{l}$ & -3.2 & $-1.8>>2$ & 1.9 & 2.73 \\
\hline Small Retail & Houston & Old & he & 803.2 & 0.72 & 0.74 & 1.5 & -1.8 & -1.4 & -0.3 & -2 & 2.00 & 305.05 & 0.75 & 0.6 & $-1.1 \mathrm{E} \quad \mathrm{E}$ & $8.2 \mathrm{E}+02$ & $-1.3 \mathrm{E}+02$ & & $-1.8 \mathrm{E}+02$ & $-1.37 E+03$ \\
\hline Small Retail & $\begin{array}{l}\text { Houston } \\
\end{array}$ & Old & cool & 511.8 & 0.72 & 0.74 & 14.6 & -1 & -1.1 & 27.6 & 40.1 & 1.92 & 298.04 & 0.75 & 0.66 & & $7.5 \mathrm{E}+03$ & $-9.5 \mathrm{E}+01$ & & $1.6 \mathrm{E}$ & $2.21 \mathrm{E}+04$ \\
\hline $\begin{array}{l}\text { Large R€ } \\
\text { Larae } R \epsilon\end{array}$ & $\begin{array}{l}\text { Total } \\
\text { Total }\end{array}$ & $\begin{array}{l}\text { Total } \\
\text { Total }\end{array}$ & $\begin{array}{l}\text { heat } \\
\text { cool }\end{array}$ & $\begin{array}{l}5296.7 \\
4115.5\end{array}$ & & & & & & & & & $\begin{array}{l}4,199.53 \\
4.18 .46\end{array}$ & & & $\begin{array}{l}-4.37 \\
-1.13 \\
\end{array}$ & $\begin{array}{l}1.58 \\
4.29\end{array}$ & $\begin{array}{l}-1.10 \\
-1.94\end{array}$ & $\begin{array}{l}-6.2 .1 \\
-1.11\end{array}$ & & \\
\hline Large Retail & Total & Total & cool & 4115.5 & & & & & & & & & 4,188.46 & & & $-1.13 E+04$ & $4.29 \mathrm{E}+04$ & $-1.94 E+03$ & $-1.10 E+04$ & $1.93 E+05$ & 2.12E+05 \\
\hline $\begin{array}{l}\text { Smaall Retail } \\
\text { Small Retail }\end{array}$ & $\begin{array}{l}\text { Total } \\
\text { Total }\end{array}$ & $\begin{array}{l}\text { Total } \\
\text { Total }\end{array}$ & $\begin{array}{l}\text { heat } \\
\text { cool }\end{array}$ & $\begin{array}{r}5749 \\
3729.6\end{array}$ & & & & & & & & & $\begin{array}{l}3,029.50 \\
2,525.17\end{array}$ & & & $\begin{array}{l}-3.70+04 \\
-1.03 E+04\end{array}$ & $5.33 E+04$ & $\begin{array}{r}-3.76 \mathrm{E}+03 \\
-1.09 \mathrm{E}+03\end{array}$ & $-6.19 E+03$ & $\begin{array}{l}-3.24 \mathrm{E}+04 \\
8.74 \mathrm{E}+04\end{array}$ & $\begin{array}{l}-8.06+04 \\
1.23 E+05\end{array}$ \\
\hline
\end{tabular}


Large and Small Hotels

\begin{tabular}{|c|c|c|c|c|c|c|c|c|c|c|c|c|c|c|c|c|c|c|c|c|c|}
\hline \multirow[b]{3}{*}{ Building Type } & \multirow[b]{3}{*}{ Climate Zone } & \multirow[b]{3}{*}{ Vintage } & \multirow{3}{*}{$\begin{array}{c}\text { Space } \\
\text { Conditioning } \\
\text { Mode }\end{array}$} & \multirow{2}{*}{\multicolumn{8}{|c|}{\begin{tabular}{l|l}
\multicolumn{2}{c}{1991 Properties Estimated by Huang and Franconi (1999) } \\
Window Properties |
\end{tabular}}} & \multirow{3}{*}{$\mid$\begin{tabular}{c|} 
System Efficiency \\
Factor \\
(Primary kBtu \\
Energy Consumption \\
/ kBtu Load)
\end{tabular}} & \multicolumn{9}{|c|}{1999 Updated Window Stock Estimates (Apte and Arasteh, 2006) } \\
\hline & & & & & & & & & & & & & \multirow{2}{*}{$\begin{array}{c}\text { Conditioned } \\
\text { Area, } \\
\text { Million Square } \\
\text { Feet }\end{array}$} & Window & roperties & & Total Bu & ding Energy C & Consumption (T) & & \\
\hline & & & & \begin{tabular}{|c} 
Conditioned \\
Area, \\
Million Square \\
Feet \\
\end{tabular} & \begin{tabular}{|l|}
\multicolumn{2}{|c|}{ Window PI } \\
U Factor
\end{tabular} & SHGC & $\begin{array}{c}\text { Window } \\
\text { Solar }\end{array}$ & $\begin{array}{c}\text { Window } \\
\text { Cond }\end{array}$ & Infiltration & $\begin{array}{l}\text { Other } \\
\text { Loads }\end{array}$ & $\begin{array}{l}\text { Total } \\
\text { Loads }\end{array}$ & & & U Factor & SHGC & Window Solar & $\begin{array}{l}\text { Window } \\
\text { Cond }\end{array}$ & $\begin{array}{c}\text { Window } \\
\text { Infiltration }\end{array}$ & $\mid \begin{array}{c}\text { Non-Window } \\
\text { Infiltration }\end{array}$ & Other Loads & Total Loads \\
\hline $\begin{array}{ll}\text { Large Hotel } \\
\text { targe Hotel }\end{array}$ & $\begin{array}{l}\text { Minneapolis } \\
\text { Minneapolis }\end{array}$ & New & heat & 18.6 & 0.60 & 0.64 & 4 & -10.2 & -3.3 & -1.6 & -11.1 & & 51.31 & 0.75 & 0.66 & $-1.8 \mathrm{E}+03$ & $5.7 \mathrm{E}+02$ & $-6.9 \mathrm{E}+01$ & $-3.9 \mathrm{E}+02$ & $-2.2 \mathrm{E}+02$ & $-1.88 \mathrm{E}+03$ \\
\hline $\begin{array}{l}\text { Large Hotel } \\
\text { Large Hotel }\end{array}$ & $\begin{array}{l}\text { Minneapolis } \\
\text { Chicago }\end{array}$ & New & cool & 18.5 & 0.60 & 0.64 & 12.3 & -2.9 & -0.9 & 12.9 & 21.4 & 1.20 & 43.23 & 0.75 & 0.66 & $-1.9 \mathrm{E}+02$ & $6.6 \mathrm{E}+02$ & 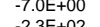 & $-4.0 E+01$ & $6.7 \mathrm{E}+02$ & 1.09E+03 \\
\hline $\begin{array}{l}\text { Large Hotel } \\
\text { Large Hotel }\end{array}$ & $\begin{array}{l}\text { Chicago } \\
\text { Chicago }\end{array}$ & $\begin{array}{l}\text { New } \\
\text { New }\end{array}$ & $\begin{array}{l}\text { heat } \\
\text { cool }\end{array}$ & $\begin{array}{l}39.8 \\
34.7\end{array}$ & $\begin{array}{l}0.60 \\
0.60\end{array}$ & $\begin{array}{l}0.64 \\
0.64\end{array}$ & $\begin{array}{l}3 \\
132\end{array}$ & $\begin{array}{l}-7.1 \\
-2.7\end{array}$ & $\begin{array}{l}-2.3 \\
-0.9 \\
\end{array}$ & $\begin{array}{l}-0.5 \\
15\end{array}$ & $\begin{array}{l}-6.9 \\
24.6\end{array}$ & $\begin{array}{l}3.03 \\
1.22\end{array}$ & $\begin{array}{l}223.08 \\
191.12\end{array}$ & $\begin{array}{l}0.75 \\
0.75\end{array}$ & $\begin{array}{l}0.66 \\
0.66\end{array}$ & $\begin{array}{l}-6.0 E+03 \\
-7.9 E+02\end{array}$ & $\begin{array}{l}2.1 \mathrm{E}+03 \\
3.2 \mathrm{E}+03\end{array}$ & $\begin{array}{l}-2.3 E+02 \\
-3.1 E+01\end{array}$ & $\begin{array}{l}-1.3 \mathrm{E}+03 \\
-1.5 \mathrm{E}+02\end{array}$ & $\begin{array}{l}-3.4 \mathrm{E}+02 \\
-35 \mathrm{E}+03\end{array}$ & $\begin{array}{l}-5.83 E+03 \\
565+03\end{array}$ \\
\hline Large Hotel & Washington & New & heat & $\begin{array}{l}34.1 \\
21.4\end{array}$ & 0.60 & $\begin{array}{l}0.64 \\
0.64\end{array}$ & $\begin{array}{c}13.2 \\
2\end{array}$ & $\begin{array}{l}-2.1 \\
-4.5\end{array}$ & $\begin{array}{l}-1.9 \\
-1.4 \\
-1.9\end{array}$ & 0.2 & $\begin{array}{l}24.6 \\
-3.7\end{array}$ & $\begin{array}{l}1.22 \\
3.57\end{array}$ & $\begin{array}{l}191.12 \\
305.54\end{array}$ & $\begin{array}{l}0.75 \\
0.75\end{array}$ & $\begin{array}{l}0.66 \\
0.66\end{array}$ & $\begin{array}{l}-1.9 E+02 \\
-6.2 E+03\end{array}$ & $\begin{array}{l}3.2 \mathrm{E}+03 \\
2.2 \mathrm{E}+03\end{array}$ & $\begin{array}{l}-3.1 \mathrm{E}+01 \\
-2.3 \mathrm{E}+02\end{array}$ & $\begin{array}{l}-1.8 \mathrm{E}+02 \\
-1.3 \mathrm{E}+03\end{array}$ & $\begin{array}{l}\text { 2. } 2.2 \mathrm{E}+02 \\
2 \mathrm{n}+02\end{array}$ & $\begin{array}{l}5.65+03 \\
-5.22 \mathrm{E}+03\end{array}$ \\
\hline Large Hotel & Washington & New & cool & 15.7 & 0.60 & 0.64 & 14.2 & -2.7 & -0.9 & 18.2 & 28.8 & 1.30 & 277.72 & 0.75 & 0.66 & $-1.2 E+03$ & $5.3 \mathrm{E}+03$ & $-4.9 \mathrm{E}+01$ & $-2.8 \mathrm{E}+02$ & $6.6 \mathrm{E}+03$ & $\begin{array}{l}-5.2<E E+03 \\
1.03 E+04\end{array}$ \\
\hline Large Hotel & Los Angeles & New & heat & 234.2 & 0.60 & 0.64 & 0.1 & -0.1 & 0 & -0.1 & -0.1 & 100.00 & 528.19 & 0.75 & 0.66 & $-6.6 \mathrm{E}+03$ & $5.4 E+03$ & $0.0 \mathrm{E}+00$ & $0.0 \mathrm{E}+00$ & $-53 E+03$ & $-648 \mathrm{E}+03$ \\
\hline Large Hotel & Los Angeles & New & cool & 218.7 & 0.60 & 0.64 & 24.4 & -6.2 & -2.4 & 24.8 & 40.6 & 1.00 & 567.94 & 0.75 & 0.66 & $-4.4 \mathrm{E}+03$ & $1.4 \mathrm{E}+04$ & $-2.0 E+02$ & $-1.2 E+03$ & $1.4 \mathrm{E}+04$ & $2.25 E+04$ \\
\hline Large Hotel & Houston & New & heat & 156 & 0.60 & 0.64 & 0.3 & -0.5 & -0.2 & 0 & -0.4 & 16.67 & 160.43 & $0.7 \mathrm{~F}-\mathrm{s}$ & & $-1.7 \mathrm{E}+03$ & $8.2 E+02$ & $-8.0 E+01$ & $-4.5 \mathrm{E}+02$ & $0.0 E+00$ & $-1.39 E+03$ \\
\hline Large Hotel & Houston & New & cool & 153.2 & 0.60 & 0.64 & 18.7 & -2.1 & -0.9 & 28.1 & 43.8 & 1.23 & 165.35 & 0.75 & 0.66 & $-5.4 \mathrm{E}+02$ & $3.9 E+03$ & $-2.8 \mathrm{E}+01$ & $-1.6 \mathrm{E}+02$ & $5.7 E+03$ & $8.93 E+03$ \\
\hline Large Hotel & Minneapolis & Old & heat & 98.1 & 0.72 & 0.71 & 4.3 & -10.3 & -3.5 & -4.5 & -14 & 2.86 & 94.15 & 0.75 & 0.66 & $-2.9 E+03$ & $1.1 \mathrm{E}+03$ & $-1.4 \mathrm{E}+02$ & $-8.0 \mathrm{E}+02$ & $-1.2 \mathrm{E}+03$ & $-3.97 \mathrm{E}+03$ \\
\hline Large Hotel & Minneapolis & Old & cool & 79.7 & 0.72 & 0.71 & 11.1 & -2.7 & -0.8 & 12.5 & 20.1 & 1.32 & 25.52 & 0.75 & 0.66 & $-9.5 \mathrm{E}+01$ & $3.4 \mathrm{E}+02$ & $-4.0 E+00$ & $-2.3 \mathrm{E}+01$ & $4.2 \mathrm{E}+02$ & $6.43 E+02$ \\
\hline Large Hotel & Chicago & Old & heat & 221 & 0.72 & 0.71 & 3.5 & -7.6 & -2.6 & -2.3 & -9 & ${ }^{3.03}$ & 582.07 & 0.75 & 0.66 & $-1.4 \mathrm{E}+04$ & $5.7 \mathrm{E}+03$ & $-6.9 E+02$ & $-3.9 \mathrm{E}+03$ & $-4.1 E+03$ & $-1.69 E+04$ \\
\hline Large Hotel & $\begin{array}{c}\text { Chicago } \\
\text { Washington }\end{array}$ & Old & cool & 92.5 & 0.72 & 0.71 & 12.1 & -2.7 & -0.9 & 14.8 & 23.3 & $\begin{array}{l}1.33 \\
3.23\end{array}$ & $\begin{array}{l}341.47 \\
19850\end{array}$ & 0.75 & 0.66 & $-1.3 \mathrm{E}+03$ & $5.1 \mathrm{E}+03$ & $-6.1 \mathrm{E}+01$ & $\begin{array}{l}-3.5 \mathrm{E}+02 \\
-8.25+0 ?\end{array}$ & $6.7 \mathrm{E}+03$ & $\begin{array}{l}1.01 E+04 \\
\text {. }\end{array}$ \\
\hline $\begin{array}{l}\text { Large Horel } \\
\text { Large Hotel }\end{array}$ & $\begin{array}{l}\text { Washingington } \\
\text { Washiton }\end{array}$ & $\begin{array}{l}\text { Old } \\
\text { Old }\end{array}$ & $\begin{array}{l}\text { heat } \\
\text { cool }\end{array}$ & $\begin{array}{l}125.6 \\
20.3\end{array}$ & $\begin{array}{l}0.72 \\
0.72\end{array}$ & 0.71 & $\begin{array}{l}2.2 \\
12.9\end{array}$ & $\begin{array}{l}-4.6 \\
-2.4\end{array}$ & $\begin{array}{l}-1.5 \\
-0.8\end{array}$ & $\begin{array}{l}-1 \\
17.9\end{array}$ & $\begin{array}{l}-4.9 \\
276\end{array}$ & $\begin{array}{l}3.23 \\
1.41\end{array}$ & $\begin{array}{l}198.50 \\
17666\end{array}$ & $\begin{array}{l}0.15 \\
0.75\end{array}$ & 0.66 & $\begin{array}{l}-3.1 \mathrm{E}+03 \\
-6.2 \mathrm{E}+02\end{array}$ & $\begin{array}{l}1.3 E+03 \\
3.0 E+03\end{array}$ & $\begin{array}{l}-1.4 E+02 \\
-3.0 E+01\end{array}$ & $\begin{array}{l}-8.2 E+02 \\
-1.2 E+02\end{array}$ & $\begin{array}{l}-6.4 E+02 \\
4.5 E+03\end{array}$ & $\begin{array}{l}-3.37 E+03 \\
660+03\end{array}$ \\
\hline $\begin{array}{l}\text { Large Hotel } \\
\text { Largel }\end{array}$ & Los Angeles & $\begin{array}{l}\text { Old } \\
\text { old }\end{array}$ & heat & $\begin{array}{l}20.5 \\
117.8\end{array}$ & 0.72 & 0.71 & 0.1 & $\begin{array}{l}-2.4 \\
-0.2\end{array}$ & $\begin{array}{l}-0.8 \\
-0.1\end{array}$ & 0.1 & $\begin{array}{l}27.6 \\
-0.1\end{array}$ & $\begin{array}{r}1.41 \\
33.33\end{array}$ & $\begin{array}{l}176.66 \\
325.08\end{array}$ & $\begin{array}{l}0.15 \\
0.75\end{array}$ & $\begin{array}{l}0.66 \\
0.66\end{array}$ & $\begin{array}{l}-6.2 \mathrm{E}+02 \\
-2.3 \mathrm{E}+03\end{array}$ & $\begin{array}{l}3.0 \mathrm{E}+03 \\
1.0 \mathrm{E}+03\end{array}$ & $\begin{array}{l}-3.0 \mathrm{E}+01 \\
-1.6 \mathrm{E}+02\end{array}$ & $\begin{array}{l}-1.7 \mathrm{E}+02 \\
-9.2 \mathrm{E}+02\end{array}$ & $\begin{array}{l}4.5 \mathrm{E}+03 \\
1.1 \mathrm{E}+03\end{array}$ & $\begin{array}{r}6.60 \mathrm{E}+03 \\
-1.26 \mathrm{E}+03\end{array}$ \\
\hline $\begin{array}{l}\text { Large Hotel } \\
\text { L }\end{array}$ & Los Angeles & Old & cool & 134.1 & 0.72 & 0.71 & 22.5 & -5.6 & -2.2 & 24 & 38.7 & 1.11 & 304.60 & 0.75 & 0.66 & $-2.0 \mathrm{E}+03$ & $7.0 \mathrm{E}+03$ & $-1.1 \mathrm{E}+02$ & $-6.3 \mathrm{E}+02$ & $8.1 \mathrm{E}+03$ & 1.24E+04 \\
\hline Large $\mathrm{H}$ & Houston & ol & he & 294.1 & 0.72 & 0.71 & 0.4 & -0.7 & -0.2 & -0.1 & -0.6 & 11.11 & 284.17 & 0.75 & 0.66 & $-2.3 E+03$ & $1.2 \mathrm{E}+03$ & $-9.5 \mathrm{E}+01$ & $-5.4 \mathrm{E}+02$ & $-3.2 E+02$ & $-2.08 E+03$ \\
\hline Large Hotel & Houston & Old & cool & 302.4 & 0.72 & 0.71 & 17.2 & -1.8 & -0.8 & 27.9 & 42.5 & 1.32 & 346.34 & 0.75 & 0.66 & $-8.6 \mathrm{E}+02$ & $7.3 E+03$ & $-5.5 \mathrm{E}+01$ & $-3.1 E+02$ & $1.3 E+04$ & $1.87 \mathrm{E}+04$ \\
\hline Small Hotel & Minneapolis & New & heat & 0 & 0.58 & 0.66 & 8.2 & -11.6 & -13.4 & -7.3 & -24.1 & 2.70 & 39.84 & 0.75 & 0.66 & $-1.6 \mathrm{E}+03$ & $8.8 E+02$ & $-2.2 \mathrm{E}+02$ & $-1.2 \mathrm{E}+03$ & $-7.9 E+02$ & $-2.95 E+03$ \\
\hline $\mathrm{Sm}$ & Min & New & cool & 0 & 0.58 & 0.66 & 10.3 & -2.2 & -1.2 & 5.4 & 12.3 & 2.27 & 38.75 & 075 & 0.66 & -2.5 & $9.1 \mathrm{E}$ & -1.66 & 000 & 4.8 & $1.03 E+03$ \\
\hline Small Hotel & Chicago & New & heat & 4.4 & 0.58 & 0.66 & 6.7 & -8.7 & -9.7 & -3.5 & -15.2 & 2.94 & 6.24 & 0.75 & 0.66 & $-2.0 \mathrm{E}+02$ & $1.2 \mathrm{E}+02$ & $-2.7 \mathrm{E}+01$ & -1.56 & -6.4 & $-3.24 E+02$ \\
\hline & We $>$ & New & & 4.4 & 0.58 & 6 & 11.5 & -2.3 & -1.2 & 7.1 & 15.1 & 2.22 & 4.93 & & 0.66 & -3.2 & 1.3 & -2.0 & & & $1.58 \mathrm{E}+02$ \\
\hline Small $\mathrm{E}$ & Washington & New & he & 15.7 & 0.58 & 0.66 & 3.8 & -5.1 & -5.5 & -0.7 & -7.5 & 3.45 & 13.96 & 0.7 & 0.66 & $-3.1 \mathrm{E}+02$ & $1.8 \mathrm{E}+02$ & $-4.0 \mathrm{E}+01$ & -2.3 & $-3.4 E+01$ & $-4.31 E+02$ \\
\hline $\mathrm{Sm}$ & Washin & New & & 17.4 & 0.58 & 0.66 & 13.6 & -2.9 & -1.6 & 9.9 & 19 & 2.44 & 14.18 & 0.7 & 0. & -1.3 & $4.7 \mathrm{E}+02$ & $-8.3 \mathrm{E}+00$ & -4.7 & 3.4 & $6.28 \mathrm{E}+02$ \\
\hline Sm & Los Angeles & New & he & 55.9 & 0.58 & 0.66 & 0.1 & -0.1 & -0.1 & 0 & -0. & 100.00 & 38.05 & & 0.6 & & 3.8 & -5.7 > & & & $-4.89 E+02$ \\
\hline $\mathrm{Sm}$ & Los Angeles & New & cool & 55.8 & 0.58 & 0.66 & 23.6 & -6 & -4.1 & 12.8 & 26.3 & 1.85 & 41.88 & 0.75 & 0.66 & $-6.0 \mathrm{E}+02$ & $1.8 \mathrm{E}+03$ & $-4.8 \mathrm{E}+01$ & $-2.7 \mathrm{E}+02$ & $9.9 \mathrm{E}+02$ & $1.90 \mathrm{E}+03$ \\
\hline Small Hotel & Houston & New & heat & 66.7 & 0.58 & 0.66 & 0.5 & -0.6 & -0.6 & 0.1 & -0.6 & 33.33 & 70.54 & 0.75 & 0.66 & $-1.8 \mathrm{E}+03$ & $1.2 \mathrm{E}+03$ & $-2.1 \mathrm{E}+02$ & $-1.2 E+03$ & $2.4 \mathrm{E}+02$ & $-1.81 E+03$ \\
\hline Small Hotel & Houston & New & cool & 67.5 & 0.58 & 0.66 & 18.3 & -2.6 & -0.2 & 12.9 & 28.4 & 2.63 & 80.01 & 0.75 & 0.66 & $-7.0 \mathrm{E}+02$ & $3.8 \mathrm{E}+03$ & $-6.3 \mathrm{E}+00$ & $-3.6 E+01$ & $2.7 \mathrm{E}+03$ & $5.82 E+03$ \\
\hline & & ol & & 103.3 & 0.69 & 0.71 & 9.7 & -14.7 & -13.3 & -9.3 & -27.6 & 2.08 & 6.90 & 0.75 & 0.66 & $-2.3 E$ & 1.3E & & 22 & & \\
\hline & Min & & & 94.8 & 0.69 & 0.71 & 12.8 & -2.8 & -1.2 & 5.8 & 14.6 & 0.18 & 7.45 & $0.7-7>3$ & 0.66 & -4.05 & $1.6 \mathrm{E}+01$ & $-2.4 t<>2$ & $-1.3 \mathrm{E}>\mathrm{C}$ & & $1.77 \mathrm{E}+01$ \\
\hline & & Old & he & 89.1 & 0.69 & 0.71 & 8 & -11 & -9.6 & -5.1 & -17.7 & 2.22 & 49.35 & 5 & 0.66 & -1.36 & $8.1 \mathrm{E}+02$ & -1.66 & $-8.9 \mathrm{E}$ & -5.66 & $-2.10 E+03$ \\
\hline Sma & & ol & co & 73 & 0.69 & 0.71 & 14.2 & -3 & -1.2 & 7.5 & 17.5 & 0.16 & 20.25 & & 0.6 & -1.0 & $4.1 \mathrm{E}$ & -5.7 & $-3.2 \mathrm{E}$ & 2.4 & $5.12 \mathrm{E}+01$ \\
\hline Sm & we & Old & he & & 0.69 & 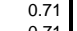 & 4.4 & -6.4 & -5.4 & -1.8 & -9.2 & 2.50 & 99.76 & - & 0.66 & -1.76 & $1.0 \mathrm{E}+03$ & & & & $-2.50 E+03$ \\
\hline & & Old & & & 0.69 & 0.71 & 16.8 & -3.8 & -1.7 & 10.5 & 21.8 & 0.16 & 68.12 & & & & & & & & \\
\hline & & Old & he & $13 \mathrm{C}$ & 0.69 & 0.71 & 0.1 & -0.2 & -0.1 & 0.1 & -0.1 & & 151.55 & & 0. & 0.0 & & & & & \\
\hline Sn & Los $A_{i}$ & Old & co & 146.2 & 0.69 & 0.71 & 28.3 & -7.1 & -3.8 & 12.9 & 30.3 & 0.14 & 69.06 & $0.7-5>3$ & $0.6-8>$ & -7.5 & $2.6 \mathrm{E}$ & $-5.6 \mathrm{E}+00$ & $-3.2 \mathrm{E}-\mathrm{C}$ & 1.3E & $2.69 \mathrm{E}+02$ \\
\hline Sn & $\mathrm{HC}$ & Old & & & 0.69 & 0.71 & 0.7 & -0.9 & -0.7 & 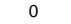 & -0.9 & 50.00 & 120.32 & 0.7 & $0.6-8>$ & & & $-6.38>>2$ & & & \\
\hline Small & Houston & Old & cool & 177.2 & 0.69 & 0.71 & 22.4 & -3.4 & -0.3 & 14.5 & 33.2 & 0.18 & 126.29 & 0.75 & 0.66 & $-8.6 \mathrm{E}$ & $4.8 \mathrm{E}+02$ & $-1.1 \mathrm{E}+00$ & $-6.0 \mathrm{E}$ & 3.4E & $7.30 \mathrm{E}+02$ \\
\hline Large $\mathrm{H}$ & To & Total & & 1326.6 & & & & & & & & & $2,752.52$ & & & -4.67 & & -1.84 & & & \\
\hline Large Hotel & Total & Total & cool & 1069.8 & & & & & & & & & $2,439.96$ & & & $-1.20 E+04$ & $4.99 \mathrm{E}+04$ & $\begin{array}{c}-5.81 E+02 \\
\end{array}$ & $-3.29 E+03$ & $6.30 \mathrm{E}+04$ & $9.70 \mathrm{E}+04$ \\
\hline $\begin{array}{l}\text { Small Hotel } \\
\text { Small Hotel }\end{array}$ & $\begin{array}{l}\text { Total } \\
\text { Total }\end{array}$ & $\begin{array}{l}\text { Total } \\
\text { Total }\end{array}$ & $\begin{array}{l}\text { heat } \\
\text { cool }\end{array}$ & $\begin{array}{l}7111.5 \\
698.8\end{array}$ & & & & & & & & & $\begin{array}{l}596.52 \\
470.92\end{array}$ & & & $\begin{array}{l}-1.35 \mathrm{E}+04 \\
-1.93 \mathrm{E}+03\end{array}$ & $\begin{array}{l}8.59+\mathrm{E}+03 \\
8.14+03\end{array}$ & $\begin{array}{l}-1.57 \mathrm{E}+03 \\
-9.03 \mathrm{E}+01\end{array}$ & $\begin{array}{l}-8.91 \mathrm{E}+03 \\
-5.12 \mathrm{E}+02\end{array}$ & $\begin{array}{l}-1.79 \mathrm{E}+03 \\
5.22 \mathrm{E}+03\end{array}$ & $\begin{array}{l}-1.72 \mathrm{E}+04 \\
1.08 \mathrm{E}+04\end{array}$ \\
\hline Small Hotel & & & & & & & & & & & & & & & & $-1.93 E+03$ & & $-9.03 E+01$ & & & $1.08 \mathrm{E}+04$ \\
\hline
\end{tabular}


Fast Food and Sit Down Restaurants

\begin{tabular}{|c|c|c|c|c|c|c|c|c|c|c|c|c|c|c|c|c|c|c|c|c|c|}
\hline \multirow[b]{3}{*}{ Building Type } & \multirow[b]{3}{*}{ Climate Zone } & \multirow[b]{3}{*}{ Vintage } & \multirow{3}{*}{$\begin{array}{c}\text { Space } \\
\text { Conditioning } \\
\text { Mode }\end{array}$} & \multirow{2}{*}{\multicolumn{8}{|c|}{\begin{tabular}{|l|l}
\multicolumn{2}{|c}{1991 Properties Estimated by Huang and Franconi (1999) } \\
Window Properties & Building HVAC Load Intensity (kBtuft/2/yr) \\
\end{tabular}}} & \multirow{3}{*}{\begin{tabular}{|c|} 
System Efficiency \\
Factor \\
(Primary kBtu \\
Energy Consumption \\
/ kBtu Load)
\end{tabular}} & \multirow{2}{*}{\multicolumn{9}{|c|}{\begin{tabular}{|l|l|l}
\multicolumn{3}{c|}{1999 Updated Window Stock Estimates (Apte and Arasteh, 2006) } \\
Window Properties & Total Building Energy Consumption (Trillion BTU/yr)
\end{tabular}}} \\
\hline & & & & & & & & & & & & & & & & & & & & & \\
\hline & & & & $\begin{array}{c}\text { Conditioned } \\
\text { Area, } \\
\text { Million Square } \\
\text { Feet }\end{array}$ & \begin{tabular}{|l|} 
U Factor \\
\end{tabular} & SHGC & $\begin{array}{c}\text { Window } \\
\text { Solar }\end{array}$ & $\begin{array}{c}\text { Window } \\
\text { Cond }\end{array}$ & Infiltration & $\begin{array}{l}\text { Other } \\
\text { Loads }\end{array}$ & $\begin{array}{l}\text { Total } \\
\text { Loads }\end{array}$ & & $\begin{array}{c}\text { Conditioned } \\
\text { Area, } \\
\text { Million Square } \\
\text { Feet }\end{array}$ & U Factor & SHGC & |Window Solar & $\begin{array}{c}\text { Window } \\
\text { Cond }\end{array}$ & $\begin{array}{c}\text { Window } \\
\text { Infiltration }\end{array}$ & $\mid \begin{array}{c}\text { Non-Window } \\
\text { Infiltration }\end{array}$ & Other Loads & Total Loads \\
\hline Fast Food Restaurant & Minneapolis & New & heat & & 0.67 & 0.70 & 12.6 & -19.1 & -1.1 & -53.2 & -60.8 & & 23.89 & 0.75 & 0.66 & $-3.2 \mathrm{E}+03$ & $1.8 \mathrm{E}+03$ & $-2.5 \mathrm{E}+01$ & $-1.4 \mathrm{E}+02$ & $-7.9 E+03$ & $-9.51 E+03$ \\
\hline Fast Food Restaurant & Minneapolis & New & cool & 1.7 & 0.67 & 0.70 & 12.6 & -1.2 & -0.3 & 32.2 & 43.3 & 1.45 & 16.92 & 0.75 & 0.66 & $-3.3 E+01$ & $2.9 \mathrm{E}+02$ & $-1.1 E+00$ & $-6.3 E+00$ & $7.9 \mathrm{E}+02$ & $1.04 E+03$ \\
\hline \begin{tabular}{|l} 
Fast Food Restaurant \\
Fast Food Restaurant
\end{tabular} & Chicago & New & heat & 35.4 & 0.67 & 0.70 & 11.6 & -15.3 & -1 & -37.5 & -42.2 & 6.67 & 63.53 & 0.75 & 0.66 & $-7.2 \mathrm{E}+03$ & 4.7E+03 & $-6.4 E+01$ & $-3.6 \mathrm{E}+02$ & $-1.6 \mathrm{E}+04$ & $-1.89 E+04$ \\
\hline $\begin{array}{l}\text { Fast Food Restaurant } \\
\text { Fast Food Restaurant }\end{array}$ & $\begin{array}{c}\text { Chicago } \\
\text { Washington }\end{array}$ & $\begin{array}{l}\text { New } \\
\text { New }\end{array}$ & $\begin{array}{c}\text { cool } \\
\text { heat }\end{array}$ & 32.4 & 0.67 & $\begin{array}{l}0.70 \\
0.70\end{array}$ & $\begin{array}{l}13.5 \\
92\end{array}$ & -1.1 & $\begin{array}{l}-0.3 \\
-0.5\end{array}$ & $\begin{array}{r}39.5 \\
-24.3\end{array}$ & $\begin{array}{l}51.6 \\
-267\end{array}$ & $\begin{array}{l}1.54 \\
667\end{array}$ & 56.98 & $\begin{array}{l}0.75 \\
0.75\end{array}$ & 0.66 & $-1.1 \mathrm{E}+02$ & $\begin{array}{l}1.1 \mathrm{E}+03 \\
4.9 \mathrm{E}+03\end{array}$ & $\begin{array}{r}-3.9 E+00 \\
-35+01\end{array}$ & $-2.2 \mathrm{E}+01$ & $3.5 \mathrm{E}+03$ & 4.45E+03 \\
\hline Fast Food Restaurant & Washington & New & $\begin{array}{l}\text { neal } \\
\text { cool }\end{array}$ & $\begin{array}{l}19.6 \\
23.6\end{array}$ & 0.67 & 0.70 & $\begin{array}{l}9.2 \\
15.1\end{array}$ & $\begin{array}{l}-11.1 \\
-0.9\end{array}$ & $\begin{array}{l}-0.5 \\
-0.3\end{array}$ & $\begin{array}{l}-24.3 \\
50.9\end{array}$ & $\begin{array}{l}-26.7 \\
64.8\end{array}$ & $\begin{array}{l}6.67 \\
1.75\end{array}$ & $\begin{array}{l}83.07 \\
80.28\end{array}$ & $\begin{array}{l}0.15 \\
0.75\end{array}$ & $\begin{array}{l}0.00 \\
0.66\end{array}$ & $\begin{array}{l}-6.9 \mathrm{E}+03 \\
-1.4 \mathrm{E}+02\end{array}$ & $\begin{array}{l}4.9 E+03 \\
2.0 E+03\end{array}$ & $\begin{array}{l}-4.2 E+01 \\
-6,3 E+00\end{array}$ & $\begin{array}{l}-2.4 \mathrm{E}+02 \\
-3.6 \mathrm{E}+01\end{array}$ & $\begin{array}{l}-1.4 E+04 \\
7.2 E+03\end{array}$ & $\begin{array}{r}-1.59 \mathrm{E}+04 \\
900 \mathrm{E}+03\end{array}$ \\
\hline Fast Food Restaurant & Los Angeles & New & heat & 21.5 & 0.67 & 0.70 & 4.2 & -3.4 & -0.1 & -4.5 & -3.8 & $\begin{array}{r}1.15 \\
14.29\end{array}$ & 65.30 & 0.75 & 0.66 & $\begin{array}{l}-1.4 \mathrm{E}+02 \\
-3.5 \mathrm{E}+03\end{array}$ & $3.7 \mathrm{E}+03$ & $-1.4 \mathrm{E}+01$ & $-7.9 \mathrm{E}+01$ & $-4.2 \mathrm{E}+03$ & $-4.12 \mathrm{E}+03$ \\
\hline Fast Food Restaurant & Los Angeles & New & cool & 24.1 & 0.67 & 0.70 & 23.6 & -2.2 & -0.2 & 59.1 & 80.3 & 1.41 & 76.74 & 0.75 & 0.66 & $-2.7 E+02$ & $2.4 \mathrm{E}+03$ & $-3.2 E+00$ & $-1.8 \mathrm{E}+01$ & $6.4 \mathrm{E}+03$ & $8.52 \mathrm{E}+03$ \\
\hline $\begin{array}{l}\text { Fast Food Restaurant } \\
\text { Fast Food Restaurant }\end{array}$ & $\begin{array}{l}\text { Houston } \\
\text { Houston }\end{array}$ & New & heat & 12.9 & 0.67 & 0.70 & 4 & -3.7 & -0.2 & -6.1 & -6 & 8.33 & $\begin{array}{l}25.61 \\
29.92\end{array}$ & 0.75 & 0.66 & $-8.8 \mathrm{E}+02$ & $8.1 \mathrm{E}+02$ & $-6.4 E+00$ & $-3.6 \mathrm{E}+01$ & $-1.3 E+03$ & 1.42E+03 \\
\hline Fast Food Restaurant & Houston & New & cool & 12.3 & 0.67 & 0.70 & & -0.2 & -0.3 & 70.6 & 91.3 & 2.33 & 29.92 & 0.75 & 0.66 & $-1.6 \mathrm{E}+01$ & $1.4 \mathrm{E}+03$ & $-3.1 \mathrm{E}+00$ & $-1.8 \mathrm{E}+01$ & $4.9 E+03$ & $6.27 \mathrm{E}+03$ \\
\hline Fast Food Restaurant & Minne & Old & heat & 38.2 & 0.65 & 0.70 & 17.7 & -28.1 & -1.1 & -54.6 & -66.1 & 5.88 & 52.31 & 0.75 & 0.66 & $-1.0 \mathrm{E}+04$ & $5.2 \mathrm{E}-$ & $-5.1 E+01$ & $-2.9 \mathrm{E}+02$ & $-1.7 E+04$ & $-2.20 E+04$ \\
\hline Fast Food Restaurant & Minneapolis & Old & cool & 32.6 & 0.65 & 0.70 & 20.1 & -2.2 & -0.2 & 30.8 & 48.5 & 1.75 & 39.95 & 0.75 & 0.66 & $-1.8 \mathrm{E}+02$ & $1.3 \mathrm{E}+03$ & $-2.1 \mathrm{E}+00$ & $-1.2 \mathrm{E}+01$ & $2.2 \mathrm{E}+03$ & $3.30 E+03$ \\
\hline Fast Food Restaurant & Chicago & Old & heat & 203.3 & 0.65 & 0.70 & 16 & -22.3 & -1.1 & -38 & -45.4 & 6.25 & 116.93 & 0.75 & 0.66 & $-1.9 E+04$ & $1.1 \mathrm{E}+04$ & $-1.2 E+02$ & $-6.8 E+02$ & $-2.8 \mathrm{E}+04$ & $-3.63 E+04$ \\
\hline Fast Food Restaurant & Chicago & Old & cool & 178.7 & 0.65 & 0.70 & 21.6 & -2.1 & -0.3 & 38 & 57.2 & 1.85 & 83.97 & 0.75 & 0.66 & $-3.8 \mathrm{E}+02$ & $3.2 \mathrm{E}+03$ & $-7.0 E+00$ & $-4.0 E+01$ & $5.9 \mathrm{E}+03$ & $8.67 E+03$ \\
\hline Restaurant & Washington & Old & heat & 144.2 & 0.65 & 0.70 & 12.4 & -16 & -0.6 & -24 & -28.2 & $6.67 \mid$ & 118.65 & 0.75 & & $-1.5 \mathrm{E}+04$ & $9.3 \mathrm{E}+03$ & $-7.1 \mathrm{E}+01$ & $-4.0 E+02$ & $-1.9 \mathrm{E}+04$ & $-2.48 \mathrm{E}+04$ \\
\hline Restaurant & Washington & Old & cool & 128.1 & 0.65 & 0.70 & 23.4 & -1.6 & -0.3 & 49.6 & 71.1 & 2.08 & 95.31 & 0.75 & 0.66 & $-3.7 E+02$ & $4.4 \mathrm{E}+03$ & $-8.9 E+00$ & $-5.1 E+01$ & $9.8 \mathrm{E}+03$ & $1.38 \mathrm{E}+04$ \\
\hline staurant & Los Angeles & Old & heat & 102.2 & 0.65 & 0.70 & 5 & -4.5 & -0.1 & -4 & -3.6 & 14.29 & 108.06 & 0.75 & 0.66 & $-8.0 E+03$ & $7.3 \mathrm{E}+03$ & $-2.3 E+01$ & $-1.3 \mathrm{E}+02$ & $-6.2 E+03$ & $-7.03 E+03$ \\
\hline Fast Food Restaurant & Los Angeles & Old & cool & 97.5 & 0.65 & 0.70 & 37.5 & -4.1 & -0.2 & 58.3 & 91.5 & 1.69 & 111.31 & 0.75 & 0.66 & $-8.9 \mathrm{E}+02$ & $6.7 \mathrm{E}+03$ & $-5.7 E+00$ & $-3.2 \mathrm{E}+01$ & 1.1E+04 & $1.68 \mathrm{E}+04$ \\
\hline Restaurant & Houston & Old & heat & 99.2 & 0.65 & 0.70 & 4.9 & -5 & -0.2 & -5.8 & -6.1 & 8.33 & 101.84 & 0.75 & 0.66 & $-4.9 E+03$ & $3.9 \mathrm{E}+03$ & $-2.5 E+01$ & $-1.4 \mathrm{E}+02$ & $-4.9 E+03$ & $-6.05 E+03$ \\
\hline Fast Food Restaurant & Houston & Old & cool & 90.8 & 0.65 & 0.70 & 32.9 & -0.7 & -0.3 & 70.1 & 102 & 2.63 & 124.22 & 0.75 & 0.66 & $-2.6 \mathrm{E}+02$ & $1.0 \mathrm{E}+04$ & $-1.5 \mathrm{E}+01$ & $-8.3 E+01$ & $2.3 E+04$ & $3.28 \mathrm{E}+04$ \\
\hline Sit-D & M & New & heat & 2.4 & 0.67 & 0.70 & 4.9 & -7.8 & -2.1 & -48.4 & -53.4 & 1.96 & 23.89 & 0.75 & 0.66 & $-4.1 E+02$ & $2.2 \mathrm{E}+02$ & $-1.5 E+01$ & $-8.4 E+01$ & $-2.3 E+03$ & $-2.56 \mathrm{E}+03$ \\
\hline & & New & co & & 67 & & 5.6 & -0.8 & & & 33 & 1.82 & & 0. & 0.66 & & & & -7.8 & & $1.01 \mathrm{E}+03$ \\
\hline Sit-D & Chica & New & heat & 35.4 & 0.67 & 0.70 & 4.4 & -6.1 & -1.7 & -32.4 & -35.8 & 1.92 & 63.53 & 0.75 & 0.66 & $-8.3 \mathrm{E}+02$ & $5.1 \mathrm{E}+02$ & $-3.1 \mathrm{E}+01$ & $-1.8 \mathrm{E}+02$ & $-4.0 \mathrm{E}+03$ & $-4.49 \mathrm{E}+03$ \\
\hline Sit-D & Chic & New & cool & 32.4 & 0.67 & 0.70 & 6.1 & -0.8 & .3 & 34.8 & 39.8 & 1.89 & 56.98 & 0.15 & 0.66 & -3.00 & $6.2 \mathrm{E}+02$ & -4.8 & -2.7 & 3.7E+03 & $4.23 \mathrm{E}+03$ \\
\hline & Wash & New & & 15 & 67 & 0.70 & 3.4 & -4.4 & -1.3 & -18.4 & -20.7 & 1.75 & & 0.75 & 0.66 & -7.2 & $4.7 \mathrm{E}+02$ & -2.9 & & & $-3.15 \mathrm{E}+03$ \\
\hline & & New & ool & 23 & 67 & 0.70 & 6.4 & -0.6 & -0.3 & 45 & 50.5 & 1.96 & 80.28 & $0.7-7>$ & 0. & -1.1 & $9.6 \mathrm{E}+02$ & -7.1 & -4.0 & & $7.89 E+03$ \\
\hline urant & & New & & 21 & 67 & & 0.7 & -0.7 & & -1.2 & & 3.13 & & 0. & & & & & & & \\
\hline Sit-Down Restaurant & Los Angeles & New & cool & 24 & 0.67 & 0.70 & 10.5 & -1.5 & -0.4 & 51.9 & 60.5 & 1.64 & 76.74 & 0. & 0. & -2.1 & $1.3 \mathrm{E}+03$ & -7.5 & $-4.3 \mathrm{E}+01$ & $6.5 \mathrm{E}+03$ & $7.52 \mathrm{E}+03$ \\
\hline Sit-Down Restaurant & Houston & New & heat & 12.9 & 0.67 & 0.70 & 1.1 & -1.1 & -0.4 & -3 & -3.4 & 2.08 & 25.61 & $0.7>>>3$ & 0.66 & $-6.6 \mathrm{E}+01$ & $5.6 \mathrm{E}+01$ & $-3.2 E+00$ & $-1.8 \mathrm{E}+01$ & $-1.6 \mathrm{E}+02$ & $-1.91 \mathrm{E}+02$ \\
\hline Sit-Down Restaurant & Houston & New & cool & 12.3 & 0.67 & 0.70 & 9 & -0.3 & -0.3 & 68.6 & 77 & 1.96 & 29.92 & 0.75 & 0.66 & $-2.0 E+01$ & $5.0 \mathrm{E}+02$ & $-2.6 \mathrm{E}+00$ & $-1.5 E+01$ & $4.0 E+03$ & $4.49 E+03$ \\
\hline & & oll & & & 0.65 & 10 & 6.5 & -10.3 & 1 & -52.5 & -58 & 96 & 52.31 & 0.75 & 0.66 & & & & & & \\
\hline & & Old & & & (ace & & 75 & 1 & & 28 & 34 & 2.22 & 39.95 & T & 0 & & & & & & \\
\hline Sit- & & Old & heat & 20 & 0.65 & & 5.8 & -8.2 & -1.7 & -35 & -39.4 & 1.92 & 116.93 & 0. & 0.66 & -2.1 & 03 & -5 & -3 & -7.5 & +03 \\
\hline & & Old & & & & & 8.1 & -1 & -0.3 & & 41.7 & 2.33 & & 0. & & & & & & & \\
\hline Sit & & ol & & & & & 4.6 & -5.9 & -1 & -2 & -2 & 1.75 & 118.65 & 0. & 0. & & & & & & $-5.03 \mathrm{E}+03$ \\
\hline Sit & w & $\mathrm{O}$ & & & & & 8.6 & -0.7 & -0 & 45.1 & & 33 & & 0 & 0 & & & & & & 1.16E+04 \\
\hline & Lo & Old & we $>$ & 102.2 & 0.65 & 0.70 & 1 & -1 & -0.4 & -1.4 & -1.8 & 2.70 & 108.06 & $0.7-7>-2$ & 0 & & & $-1.8 \mathrm{E}+01$ & & & $5.86 \mathrm{E}+02$ \\
\hline Sit & $\operatorname{Los} \mathrm{Ar}^{2}$ & Old & cool & 97 & 0.65 & 0.70 & 13.9 & -1.8 & 0 & 52 & 63.8 & 04 & 111.31 & 0. & 0 & & & -1.0 & & & \\
\hline & & ( & $\mathrm{h}$ & 99 & 0.65 & 0.70 & 1.4 & -1.5 & -0.4 & -3.5 & -4 & 2.00 & & 0.7 & 0.6 & & & -1. & & & \\
\hline Sit-Down Restaurant & Houston & Old & cool & 90.8 & 0.65 & 0.70 & 12.1 & -0.4 & -0.3 & 69.2 & 80.6 & 2.38 & 124.22 & 0.75 & 0.66 & $-1.4 \mathrm{E}+02$ & $3.4 \mathrm{E}+03$ & $-1.3 \mathrm{E}+01$ & $-7.5 \mathrm{E}+01$ & $2.0 E+04$ & $2.36 \mathrm{E}+04$ \\
\hline \begin{tabular}{|l|} 
Fast Food \\
\end{tabular} & To & $\begin{array}{l}\text { Total } \\
\text { Total }\end{array}$ & he & 678.9 & & & & & & & & & 759.99 & & & & & & & & $-1.46 E+05$ \\
\hline Fast Food Restaurant & To & $T^{T}$ & 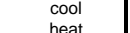 & 62 & & & & & & & & & 715.59 & & & & & & & & \\
\hline $\begin{array}{l}\text { Sit-Down Restaurant } \\
\text { Sit-Down Restaurant }\end{array}$ & $\begin{array}{l}\text { Total } \\
\text { Total }\end{array}$ & $\begin{array}{l}\text { Total } \\
\text { Total }\end{array}$ & $\begin{array}{l}\text { heat } \\
\text { cool }\end{array}$ & $\begin{array}{l}678.9 \\
621.8\end{array}$ & & & & & & & & & $\begin{array}{l}559.99 \\
715.59\end{array}$ & & & $\begin{array}{l}-7.65 \mathrm{E}+03 \\
-1.58 \mathrm{E}+03\end{array}$ & $\begin{array}{l}4.722+03 \\
1.38 E+04\end{array}$ & $\begin{array}{l}-2.47 \mathrm{E}+02 \\
-6.98 \mathrm{E}+01\end{array}$ & $\begin{array}{l}-1.4 E+03 \\
-3.95 E+02\end{array}$ & $\begin{array}{l}-2.80 E+04 \\
7.39 E+04\end{array}$ & $\begin{array}{r}-3.26 \mathrm{E}+04 \\
8.57 \mathrm{E}+04\end{array}$ \\
\hline
\end{tabular}


Hospitals and Schools

\begin{tabular}{|c|c|c|c|c|c|c|c|c|c|c|c|c|c|c|c|c|c|c|c|c|c|}
\hline \multirow[b]{2}{*}{ Building Type } & \multirow[b]{2}{*}{ Climate Zone } & \multirow[b]{2}{*}{ Vintage } & \multirow[b]{2}{*}{$\begin{array}{c}\text { Space } \\
\text { Conditioning } \\
\text { Mode }\end{array}$} & \multicolumn{8}{|c|}{\begin{tabular}{|l|l|}
\multicolumn{2}{|c|}{1991 Properties Estimated by Huang and Franconi (1999) } \\
Window Properties & Building HVAC Load Intensity ( $k$ Btufftelyr) \\
\end{tabular}} & \multirow[b]{2}{*}{$\begin{array}{l}\text { System Efficieicy } \\
\text { Factor } \\
\text { (Primary kBtu } \\
\text { Energy Consumption } \\
\text { / kBtu Loadd) }\end{array}$} & \multicolumn{9}{|c|}{ ock Estimates (Apte and Arasteh, 2006) } \\
\hline & & & & $\begin{array}{c}\text { Conditioned } \\
\text { Area, } \\
\text { Million Square } \\
\text { Feet }\end{array}$ & U Factor & SHGC & $\begin{array}{l}\text { Window } \\
\text { Solar }\end{array}$ & $\begin{array}{l}\text { Window } \\
\text { Cond }\end{array}$ & Infiltration & $\begin{array}{l}\text { Other } \\
\text { Loads }\end{array}$ & $\begin{array}{l}\text { Total } \\
\text { Loads }\end{array}$ & & $\begin{array}{c}\text { Conditioned } \\
\text { Area, } \\
\text { Million Square } \\
\text { Feet }\end{array}$ & U Factor & SHGC & Window Solar & $\begin{array}{l}\text { Total Bu } \\
\text { Window } \\
\text { Cond }\end{array}$ & $\begin{array}{l}\text { Window } \\
\text { Infiltration }\end{array}$ & \begin{tabular}{c|c|} 
Non-Window \\
Infiltration
\end{tabular} & Other Loads & Total Loads \\
\hline Hospital & Minneapolis & New & heat & 0 & 0.51 & 0.57 & 1.8 & -5 & 0 & -3.7 & -6.9 & 5.88 & 32.09 & 0.75 & 0.66 & $-1.4 \mathrm{E}+03$ & $3.9 \mathrm{E}+02$ & $0.0 \mathrm{E}+00$ & $0.0 E+00$ & $-7.0 \mathrm{E}+02$ & $-1.70 \mathrm{E}+03$ \\
\hline Hospital & Minneapolis & New & cool & 0 & 0.51 & 0.57 & 12.1 & -5.7 & 0 & 88 & 94.4 & 0.83 & 23.43 & 0.75 & 0.66 & $-1.6 \mathrm{E}+02$ & $2.7 \mathrm{E}+02$ & $0.0 E+00$ & $0.0 E+00$ & $1.7 \mathrm{E}+03$ & $1.81 \mathrm{E}+03$ \\
\hline Hospital & Chicago & New & heat & 85.7 & 0.51 & 0.57 & 1.5 & -3.6 & 0 & -2.2 & -4.3 & 7.69 & 149.67 & 0.75 & 0.66 & $-6.1 E+03$ & $2.0 \mathrm{E}+03$ & $0.0 \mathrm{E}+00$ & $0.0 E+00$ & $-2.5 \mathrm{E}+03$ & $-6.64 \mathrm{E}+03$ \\
\hline Hospital & Chicago & New & cool & 84.4 & 0.51 & 0.57 & 12.9 & -5.5 & 0 & 95.7 & 103.1 & 0.85 & 142.36 & 0.75 & 0.66 & $-9.8 \mathrm{E}+02$ & $1.8 \mathrm{E}+03$ & $0.0 E+00$ & $0.0 E+00$ & $1.2 E+04$ & $1.25 \mathrm{E}+04$ \\
\hline Hospital & Washington & New & heat & 42.7 & 0.51 & 0.57 & 0.5 & -1.4 & 0 & -0.8 & -1.7 & 12.50 & 65.71 & 0.75 & 0.66 & $-1.7 \mathrm{E}+03$ & $4.7 \mathrm{E}+02$ & $0.0 E+00$ & $0.0 E+00$ & $-6.6 \mathrm{E}+02$ & $-1.88 \mathrm{E}+03$ \\
\hline Hospital & Washington & New & cool & 42.4 & 0.51 & 0.57 & 13.8 & -4.7 & 0 & 107.5 & 116.6 & 0.92 & 64.61 & 0.75 & 0.66 & $-4.1 E+02$ & $9.4 E+02$ & $0.0 E+00$ & $0.0 E+00$ & $6.4 \mathrm{E}+03$ & $6.90 E+03$ \\
\hline Hospital & Los Angeles & New & heat & 43.5 & 0.51 & 0.57 & 0 & 0 & 0 & 0 & 0 & & 101.83 & 0.75 & 0.66 & $0.0 E+00$ & $0.0 E+00$ & $0.0 E+00$ & $0.0 E+00$ & $0.0 E+00$ & $0.00 E+00$ \\
\hline Hospital & Los Angeles & New & cool & 34.5 & 0.51 & 0.57 & 22.2 & -6.8 & 0 & 127.4 & 142.8 & 0.83 & 101.49 & 0.75 & 0.66 & $-8.4 \mathrm{E}+02$ & $2.1 \mathrm{E}+03$ & $0.0 \mathrm{E}+00$ & $0.0 E+00$ & $1.1 \mathrm{E}+04$ & $1.20 E+04$ \\
\hline $\begin{array}{l}\text { Hospital } \\
\text { Hospital }\end{array}$ & $\begin{array}{l}\text { Houston } \\
\text { Houston }\end{array}$ & $\begin{array}{l}\text { New } \\
\text { New }\end{array}$ & $\begin{array}{l}\text { heat } \\
\text { cool }\end{array}$ & $\begin{array}{l}8.6 \\
8.6\end{array}$ & $\begin{array}{l}0.51 \\
0.51\end{array}$ & $\begin{array}{l}0.57 \\
0.57\end{array}$ & $\begin{array}{c}0 \\
16.4\end{array}$ & $\begin{array}{l}-0.1 \\
-2.9\end{array}$ & $\begin{array}{l}0 \\
0\end{array}$ & $\begin{array}{c}0 \\
126.8\end{array}$ & $\begin{array}{l}-0.1 \\
140.3\end{array}$ & $\begin{array}{r}100.00 \\
1.03\end{array}$ & $\begin{array}{l}76.10 \\
75.63\end{array}$ & $\begin{array}{l}0.75 \\
0.75\end{array}$ & $\begin{array}{l}0.66 \\
0.66\end{array}$ & $\begin{array}{l}-1.1 \mathrm{E}+03 \\
-3.3 E+02\end{array}$ & $\begin{array}{l}0.0 \mathrm{E}+00 \\
1.5 \mathrm{E}+03\end{array}$ & $\begin{array}{l}0.0 E+00 \\
0.0 E+00\end{array}$ & $\begin{array}{l}0.0 E+00 \\
0.0 E+00\end{array}$ & $\begin{array}{l}0.0 E+00 \\
9.9 E+03\end{array}$ & $\begin{array}{l}-1.12 E+03 \\
1.10 E+04\end{array}$ \\
\hline Hospital & Minneapolis & Old & heat & 71.1 & 0.56 & 0.62 & 3.2 & -8.3 & 0 & -6.3 & -11.4 & 9.09 & 148.59 & 0.75 & 066 & $-1.5 E+04$ & $46 \mathrm{E}+03$ & $0,0 E+00$ & $0.0 E+00$ & $-8.5 E+03$ & (80F+od \\
\hline$H_{H}$ & Minneapolis & Old & cool & 46.6 & 0.56 & 0.62 & 10.7 & -3.8 & 0 & 72.4 & 79.3 & 0.97 & 120.63 & $0.7-3>$ & 0 & $-6.055<>2$ & $1.3 \mathrm{E}+03$ & $0.0 E+00$ & 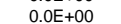 & & $9.22 E+03$ \\
\hline Hospital & Chicago & Old & heat & 324.4 & 0.56 & 0.62 & 2.6 & -5.6 & 0 & -4 & -7 & 12.50 & 381.33 & 0.75 & 0.66 & $\begin{array}{l}-3.6 \mathrm{E}+04 \\
-\end{array}$ & $1.3 \mathrm{E}+04$ & $\begin{array}{l}0.0 \mathrm{E}+00 \\
0.00\end{array}$ & $0.0 \mathrm{E}+00$ & $-1.9 E+04$ & $-4.17 E+04$ \\
\hline Hospital & Chicago & Old & cool & 285.7 & 0.56 & 0.62 & 11.9 & -4.3 & 0 & 79.7 & 87.3 & 1.02 & 261.80 & 0.75 & 0.66 & $-1.5 \mathrm{E}+03$ & $3.4 \mathrm{E}+03$ & $0.0 \mathrm{E}+00$ & $0.0 \mathrm{E}+00$ & 2.1E+04 & $2.31 \mathrm{E}+04$ \\
\hline Hospital & Washington & Old & heat & 199.9 & 0.56 & 0.62 & 1.2 & -2.9 & 0 & -1.5 & -3.2 & 20.00 & 384.17 & 0.75 & 0.66 & $-3.0 E+04$ & $9.9 \mathrm{E}+03$ & $0.0 E+00$ & $0.0 E+00$ & $-1.2 E+04$ & $-3.16 \mathrm{E}+04$ \\
\hline Hospital & Washington & Old & cool & 152.1 & 0.56 & 0.62 & 12.9 & -4.1 & 0 & 89.9 & 98.7 & 1.10 & 346.76 & 0.75 & 0.66 & $-2.1 \mathrm{E}+03$ & $5.3 \mathrm{E}+03$ & $0.0 E+00$ & $0.0 E+00$ & 3.4E+04 & $3.74 \mathrm{E}+04$ \\
\hline Hospital & Los Angeles & Old & heat & 390.4 & 0.56 & 0.62 & 0 & -0.1 & 0 & 0 & -0.1 & & 259.98 & 0.75 & 0.66 & $0.0 \mathrm{E}+00$ & $0.0 \mathrm{E}+00$ & $0.0 \mathrm{E}+00$ & $.0 E+00$ & $0.0 E+00$ & $0.00 E+00$ \\
\hline Hospital & Los Angeles & Old & cool & 389.3 & 0.56 & 0.62 & 20.7 & -5.8 & 0 & 105.5 & 120.4 & 1.01 & 253.14 & 0.75 & 0.66 & $-2.0 E+03$ & $5.7 \mathrm{E}+03$ & $0.0 E+00$ & 00 & $2.7 E+04$ & 3.06E+04 \\
\hline $\begin{array}{l}\text { Hospital } \\
\text { Hosinita }\end{array}$ & $\begin{array}{l}\text { Houston } \\
\text { Houston }\end{array}$ & Old & heat & $\begin{array}{ll}117.6 \\
1239\end{array}$ & 0.56 & 0.62 & $\begin{array}{r}0.1 \\
15.8\end{array}$ & -0.3 & 0 & $\begin{array}{l}-0.1 \\
-097\end{array}$ & $\begin{array}{c}-0.3 \\
1231\end{array}$ & 100.00 & $\begin{array}{l}140.05 \\
-190.99\end{array}$ & $\begin{array}{l}0.75 \\
0.75\end{array}$ & 0.66 & $\begin{array}{l}-5.6 \mathrm{E}+03 \\
-7 \mathrm{E}+02\end{array}$ & $\begin{array}{l}1.5 \mathrm{E}+03 \\
40 \mathrm{E}+03\end{array}$ & $\begin{array}{l}0.0 E+00 \\
0.0 E+00\end{array}$ & $\begin{array}{l}0.0 E+00 \\
0.0+00\end{array}$ & $-1.4 \mathrm{E}+03$ & $-5.54 E+03$ \\
\hline Hospital & Houston & Old & cool & 123.9 & 0.56 & 0.62 & 15.8 & -2.4 & 0 & 109.7 & 123.1 & 1.23 & 190.49 & 0.75 & 0.66 & $-7.6 \mathrm{E}+02$ & $4.0 E+03$ & $0.0 E+00$ & $0.0 E+00$ & $2.6 \mathrm{E}+04$ & $2.90 \mathrm{E}+04$ \\
\hline School & Minneapolis & New & heat & 102.6 & 0.58 & 0.62 & 5.1 & -9 & -18.1 & -21.6 & -43.6 & 2.33 & 285.50 & 0.75 & 0.66 & $-7.7 \mathrm{E}+03$ & $3.6 \mathrm{E}+03$ & $-1.8 \mathrm{E}+03$ & $-1.0 E+04$ & $-1.4 \mathrm{E}+04$ & $-3.04 E+04$ \\
\hline $\mathrm{Scl}$ & Minneapolis & New & cc & & 0.58 & 0.62 & 2.8 & -0.6 & -1.1 & 4.1 & 5.2 & 2.38 & 123.50 & To & 0.66 & -2.3 & 8.8 & -4.9 & & & $1.54 \mathrm{E}+03$ \\
\hline School & Chicago & New & heat & 228.4 & 0.58 & 0.62 & 4.8 & -7.2 & -14.5 & -14.9 & -31.8 & 2.33 & 477.16 & 0.75 & 0.66 & -1.0 & 5.7 & -2. & & & \\
\hline $\begin{array}{l}\text { School } \\
\text { School }\end{array}$ & Washington & New & cool & 185.2 & 0.58 & 0.62 & 3.1 & -0.7 & -1.1 & 5 & 6.3 & 2039 & 278.72 & 0.75 & 0.66 & 02 & 2. & -1 & 02 & 3.2 & +03 \\
\hline $\begin{array}{l}\text { School } \\
\text { School }\end{array}$ & $\begin{array}{l}\text { Washington } \\
\text { Washington }\end{array}$ & $\begin{array}{l}\mathrm{New} \\
\text { New }\end{array}$ & $\begin{array}{l}\text { heat } \\
\text { cool }\end{array}$ & $\begin{array}{l}172.2 \\
169.4\end{array}$ & $\begin{array}{l}0.59 \\
0.59\end{array}$ & 0.63 & 4.5 & -5.5 & -10.7 & -9.5 & $\begin{array}{l}-21.2 \\
80\end{array}$ & $\begin{array}{r}2.38 \\
2.38\end{array}$ & $\begin{array}{l}374.74 \\
331817\end{array}$ & 0.75 & 0.66 & $-6.2 \mathrm{E}+03$ & $\begin{array}{l}4.2 \mathrm{E}+03 \\
3.2 \mathrm{E}+03\end{array}$ & $\begin{array}{r}-1.4 \mathrm{E}+03 \\
\end{array}$ & $\begin{array}{l}-8.1 \mathrm{E}+03 \\
-\end{array}$ & $\begin{array}{l}-8.5 \mathrm{E}+03 \\
5.5 \mathrm{~F}+03\end{array}$ & $\begin{array}{l}-2.00 \mathrm{E}+04 \\
674 \mathrm{E}+03\end{array}$ \\
\hline $\begin{array}{l}\text { School } \\
\text { School }\end{array}$ & $\begin{array}{l}\text { Wasinington } \\
\text { Los Angeles }\end{array}$ & $\begin{array}{l}\text { New } \\
\text { New }\end{array}$ & $\begin{array}{l}\text { cool } \\
\text { heat }\end{array}$ & $\begin{array}{l}169.4 \\
206.8\end{array}$ & $\begin{array}{l}0.59 \\
0.60\end{array}$ & $\begin{array}{l}0.63 \\
0.64\end{array}$ & $\begin{array}{c}4 \\
3.9\end{array}$ & $\begin{array}{l}-0.8 \\
-26\end{array}$ & -1.5 & $\begin{array}{l}7.2 \\
-1.9\end{array}$ & $\begin{array}{l}8.9 \\
-57\end{array}$ & 2.38 & 338.17 & 0.75 & 0.66 & $\begin{array}{l}-7.7 \mathrm{E}+02 \\
-5.2 \mathrm{~F}+03\end{array}$ & $\begin{array}{l}3.2 E+03 \\
64 E+03\end{array}$ & $\begin{array}{l}-1.1 \mathrm{~K}+02 \\
-1.2 \mathrm{~F}+03\end{array}$ & $\begin{array}{l}-9.1 E+02 \\
-6.9 F+03\end{array}$ & $\begin{array}{l}5.5 E+03 \\
-30 E+03\end{array}$ & $\begin{array}{l}6.14 \mathrm{E}+03 \\
-9.85 \mathrm{E}+3\end{array}$ \\
\hline $\begin{array}{l}\text { School } \\
\text { School }\end{array}$ & $\begin{array}{l}\text { Los Angeles } \\
\text { Los Anges }\end{array}$ & New & $\begin{array}{l}\text { neat } \\
\text { cool }\end{array}$ & $\begin{array}{l}206.8 \\
206.4\end{array}$ & $\begin{array}{l}0.60 \\
0.60\end{array}$ & $\begin{array}{l}0.64 \\
0.64\end{array}$ & $\begin{array}{c}3.9 \\
4\end{array}$ & $\begin{array}{l}-2.6 \\
-0.8\end{array}$ & $\begin{array}{l}-5.1 \\
-0.7\end{array}$ & $\begin{array}{l}-1.9 \\
8.2\end{array}$ & $\begin{array}{l}-5.7 \\
10.7\end{array}$ & $\begin{array}{l}4.00 \\
2.50\end{array}$ & $\begin{array}{l}367.12 \\
367.53\end{array}$ & $\begin{array}{l}0.75 \\
0.75\end{array}$ & 0.66 & $\begin{array}{l}-5.2 E+03 \\
-9.2 E+02\end{array}$ & $\begin{array}{l}6.4 \mathrm{E}+03 \\
3.8 \mathrm{E}+03\end{array}$ & $\begin{array}{l}-1.2 \mathrm{Z}+03 \\
-9.6 \mathrm{E}+01\end{array}$ & $\begin{array}{l}-6.9 E+03 \\
-5.5 E+02\end{array}$ & $\begin{array}{l}-3.0 \mathrm{E}+03 \\
7.5 \mathrm{E}+03\end{array}$ & $\begin{array}{l}-9.985 \mathrm{E}+03 \\
9.79 \mathrm{E}+03\end{array}$ \\
\hline School & Houston & New & heat & 189.8 & 0.60 & 0.64 & 3.1 & -2.3 & -4.2 & -3.1 & -6.5 & 3.13 & 358.11 & 0.75 & 0. & -3.2 & & o.tint & . & & $-7.79 \mathrm{E}+03$ \\
\hline School & Houston & New & cool & 188.5 & 0.60 & 0.64 & 6.5 & -0.8 & -1 & 11.2 & 15.9 & 2.50 & 339.82 & 0.75 & 0.6 & $-8.5 E+02$ & $5.7 \mathrm{E}+03$ & $-1.3 \mathrm{E}+02$ & $-7.2 E+02$ & $9.5 \mathrm{E}+03$ & $1.36 \mathrm{E}+04$ \\
\hline School & M & Old & heat & & 0.63 & & 6.1 & -10.4 & -18.1 & -23.9 & -46.3 & 1.64 & 499.71 & $0.7-3>1$ & 0.66 & -1.0 & 4.7 & & -1.3 & & \\
\hline chor & Minne & 0 & & & & & 3.6 & -0 & & & & & 164.92 & & & & & 0.0 & & & $0.00 E+00$ \\
\hline Sch & 5 & Old & he & & 0.63 & 0. & 5.6 & -8.4 & -14.5 & -16.5 & -33.8 & 1.64 & 1,998.88 & 0. & 0 & & & -7.1 & -4.0 & & $-1.17 \mathrm{E}+05$ \\
\hline School & $c$ & 이 & c & 10 & 0.63 & 0. & 4.1 & -0.9 & -1.0 & 5 & 6.9 & & 894.43 & & 0 & $0.0 \mathrm{E}+00$ & & 0.0 & & $0.0 \mathrm{E}+00$ & $0.00 E+00$ \\
\hline School & Washington & Old & he & 1828.2 & 0.67 & 0.71 & 5.5 & -6.9 & -10.7 & -11 & -23.1 & 1.59 & $1,753.40$ & 0.75 & 0.66 & $-2.2 E+04$ & 1.4E+04 & $-4.5 E+03$ & $-2.5 E+04$ & $-3.1 E+04$ & $-6.77 \mathrm{E}+04$ \\
\hline School & Washington & Old & $\cos -2$ & 964 & 0.67 & 0.71 & 5.6 & -1.2 & -1.6 & 7.1 & 9.9 & & 949.82 & 0.75 & 0.66 & $0.0 E+00$ & $0.0 E+00$ & $0.0 E+00$ & $0.0 E+00$ & $0.0 E+00$ & $0.00 E+00$ \\
\hline School & es & Old & heat & 1582.7 & 0.72 & 0.72 & 4.4 & -3.2 & -5.1 & -2.3 & -6.2 & 1.54 & $1,344.33$ & $0.7-7>$ & $0.6-2>3$ & -6.9 & $8.3 \mathrm{E}+03$ & $-1.6 \mathrm{E}+03$ & $-9.0 E+03$ & -4.8 & $-1.39 E+04$ \\
\hline Sch & $\operatorname{Los} \mathrm{A}$ & Old & $\mathrm{co}+2-$ & 1511.6 & 0.72 & 0.72 & 5.8 & -1.3 & -0.8 & 8.5 & 12.2 & & $1,096.70$ & $0.7 \mathrm{r}>\mathrm{C}$ & $0.6>>>$ & & 0.0 & 0.0 & 0.0 & & +00 \\
\hline School & Houston & Old & heat & 1116 & 0.72 & 0.72 & 3.7 & -3 & -4.2 & -3.5 & -7 & 1.59 & 804.60 & 0.75 & 0.66 & $-4.0 \mathrm{E}+03$ & $4.3 \mathrm{E}+03$ & $-8.0 \mathrm{E}+02$ & $-4.6 \mathrm{E}+03$ & $-4.5 \mathrm{E}+03$ & $-9.51 E+03$ \\
\hline School & Houston & Old & cool & 1048.5 & 0.72 & 0.72 & 8.9 & -1.2 & -1.3 & 11.8 & 18.2 & & 807.74 & 0.75 & 0.66 & $0.0 \mathrm{E}$ & $0.0 \mathrm{E}+00$ & $0.0 \mathrm{E}+00$ & $0.0 \mathrm{E}$ & & $0.00 \mathrm{E}+00$ \\
\hline $\begin{array}{l}\text { Hospital } \\
\text { Hospital }\end{array}$ & $\begin{array}{l}\text { To } \\
\text { To }\end{array}$ & $\begin{array}{l}\text { Total } \\
\text { Total }\end{array}$ & he & $\begin{array}{l}1283.9 \\
1167.5\end{array}$ & & & & & & & & & $\begin{array}{l}1,739.52 \\
1580.32\end{array}$ & & & $\begin{array}{l}-9.67 \\
-9.71\end{array}$ & $\begin{array}{l}3.21 \\
2.62\end{array}$ & $\begin{array}{l}0.00 \\
0.00\end{array}$ & $\begin{array}{l}0.0 \\
0.0\end{array}$ & $\begin{array}{l}-4.4 \\
1.5\end{array}$ & $\begin{array}{l}-1.05 \\
1.74\end{array}$ \\
\hline $\begin{array}{l}\text { Hospital } \\
\text { School }\end{array}$ & $\begin{array}{l}\text { To } \\
\text { To }\end{array}$ & Total & $\mathrm{cot}-\mathrm{s}$ & & & & & & & & & & $\begin{array}{l}1,580.32 \\
8,293.54\end{array}$ & & & $\begin{array}{r}-9.71 E+03 \\
-108 E+05\end{array}$ & $\begin{array}{l}2.62 \mathrm{E}+04 \\
7.26 \mathrm{~F}+04\end{array}$ & $\begin{array}{r}0.00 \mathrm{E}+00 \\
-2.38 \mathrm{E}+04\end{array}$ & $\begin{array}{l}0.00 E+00 \\
-1.35 E+05\end{array}$ & $\begin{array}{r}1.57 \mathrm{E}+05 \\
-1.5 \mathrm{E}+05\end{array}$ & $\begin{array}{l}1.74 \mathrm{E}+05 \\
-3.53 \mathrm{E}+05\end{array}$ \\
\hline $\begin{array}{l}\text { School } \\
\text { School }\end{array}$ & Total & Total & $\begin{array}{l}\text { cool } \\
\text { cool }\end{array}$ & $\begin{array}{l}8655.2 \\
5620.4\end{array}$ & & & & & & & & & $\begin{array}{l}8,293.54 \\
5,341.35\end{array}$ & & & $\begin{array}{l}-1.08 \mathrm{E}+0505 \\
-3.3 \mathrm{E}+03\end{array}$ & $\begin{array}{l}. \angle 26 \mathrm{E}+04 \\
1.57 \mathrm{E}+04\end{array}$ & $\begin{array}{l}-2.3 .5 \mathrm{E}+04 \\
-5.47 \mathrm{E}+02\end{array}$ & $\begin{array}{l}-1.35+05 \\
-3.10 \mathrm{E}+03\end{array}$ & $\begin{array}{r}-1.59 \mathrm{E}+05 \\
2.69 \mathrm{E}+04\end{array}$ & $\begin{array}{l}-3.535 \mathrm{E}+05 \\
3.56 \mathrm{E}+04\end{array}$ \\
\hline
\end{tabular}


Supermarkets, Warehouses, and Totals

\begin{tabular}{|c|c|c|c|c|c|c|c|c|c|c|c|c|c|c|c|c|c|c|c|c|c|}
\hline \multirow[b]{3}{*}{ Building Type } & \multirow[b]{3}{*}{ Climate Zone } & \multirow[b]{3}{*}{ Vintage } & \multirow{3}{*}{$\begin{array}{c}\text { Space } \\
\text { Conditioning } \\
\text { Mode }\end{array}$} & \multirow{2}{*}{\multicolumn{9}{|c|}{$\begin{array}{l}1991 \text { Properties Estimated by Huang and Franconi (1999) } \\
\text { Window Properties / } \\
\text { Building HVAC Load Intensity (kBtuftet/yr) }\end{array}$}} & \multirow{2}{*}{\multicolumn{9}{|c|}{\begin{tabular}{|c|c|}
\multicolumn{2}{|c|}{1999 Updated Window Stock Estimates (Apte and Arasteh, 2006) } \\
Window Properties I
\end{tabular}}} \\
\hline & & & & \multirow[b]{2}{*}{\begin{tabular}{|c|} 
Conditioned \\
Area, \\
Million Square \\
Feet
\end{tabular}} & \multirow{2}{*}{$\begin{array}{l}\text { Window } \\
\text { U Factor }\end{array}$} & \multirow{2}{*}{$\begin{array}{ll}\text { roperties } \\
\text { SHGC }\end{array}$} & & & & & \multirow{2}{*}{$\begin{array}{l}\text { yr) } \\
\text { Total } \\
\text { Loads }\end{array}$} & \multirow{2}{*}{\begin{tabular}{|c|} 
System Efficiency \\
Factor \\
(Primary kBtu \\
Energy Consumption \\
/ kBtu Laad)
\end{tabular}} & & & & & & & & & \\
\hline & & & & & & & $\begin{array}{l}\text { Bu } \\
\begin{array}{c}\text { Window } \\
\text { Solar }\end{array} \\
\end{array}$ & $\begin{array}{l}\text { Window } \\
\text { Cond }\end{array}$ & Infiltration & $\begin{array}{l}\text { Other } \\
\text { Loads }\end{array}$ & & & 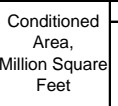 & U Factor & SHGC & Window Solar & $\begin{array}{l}\text { Window } \\
\text { Cond }\end{array}$ & $\begin{array}{c}\text { Window } \\
\text { Infittration }\end{array}$ & $\begin{array}{c}\text { Non-Window } \\
\text { Infiltration }\end{array}$ & Other Loads & Total Loads \\
\hline Supermarket & Minneapolis & New & heat & & 0.63 & 0.69 & 3.1 & -6.3 & -3.2 & -13.5 & -19.9 & & 83.25 & 0.75 & 0.66 & $-1.2 \mathrm{E}+03$ & $4.9 \mathrm{E}+02$ & $-7.8 \mathrm{E}+01$ & $-4.4 E+02$ & $-2.2 E+03$ & $-3.47 E+03$ \\
\hline Supermarket & Minneapolis & New & cool & 3.4 & 0.63 & 0.69 & 6.6 & -1.1 & -0.7 & 36.4 & 41.2 & 2.22 & 71.36 & 0.75 & 0.66 & $-2.1 \mathrm{E}+02$ & $1.0 \mathrm{E}+03$ & $-1.7 E+01$ & $-9.4 E+01$ & $5.8 \mathrm{E}+03$ & $6.46 \mathrm{E}+03$ \\
\hline Supermarket & $\begin{array}{l}\text { Chicago } \\
\text { Chicago }\end{array}$ & $\begin{array}{l}\text { New } \\
\text { New }\end{array}$ & heat & 60.9 & 0.63 & 0.69 & 2.4 & -4.4 & -2.1 & -7 & -11.1 & 1.75 & 63.70 & 0.75 & 0.66 & $-5.9 \mathrm{E}+02$ & $2.6 \mathrm{E}+02$ & $-3.5 E+01$ & $-2.0 \mathrm{E}+02$ & $-7.8 \mathrm{E}+02$ & $-1.35 E+03$ \\
\hline $\begin{array}{l}\text { Supermarket } \\
\text { Supermaketet }\end{array}$ & $\begin{array}{c}\text { Chicago } \\
\text { Washington }\end{array}$ & $\begin{array}{l}\text { New } \\
\text { New }\end{array}$ & $\begin{array}{c}\text { cool } \\
\text { ceat }\end{array}$ & $\begin{array}{l}60.9 \\
578\end{array}$ & 0.63 & $\begin{array}{l}0.69 \\
0.69\end{array}$ & 7.3 & -1.3 & -0.8 & $\begin{array}{l}43.1 \\
-2.2\end{array}$ & 48.3 & $\begin{array}{l}2.27 \\
1.37\end{array}$ & 59.89 & 0.75 & 0.66 & $-2.1 \mathrm{E}+02$ & $\begin{array}{l}9.5 \mathrm{E}+02 \\
7\end{array}$ & $-1.6 \mathrm{E}+01$ & $-9.3 \mathrm{E}+01$ & $5.9 \mathrm{E}+03$ & $6.50 \mathrm{E}+03$ \\
\hline Supermarket & Washington & New & $\begin{array}{l}\text { heat } \\
\text { cool }\end{array}$ & $\begin{array}{l}57.8 \\
53.4\end{array}$ & $\begin{array}{l}0.63 \\
0.63\end{array}$ & $\begin{array}{l}0.69 \\
0.69\end{array}$ & $\begin{array}{l}1 \\
7.8\end{array}$ & $\begin{array}{l}-2 \\
-1\end{array}$ & $\begin{array}{l}-1.1 \\
-0.7\end{array}$ & $\begin{array}{l}-2.2 \\
51.8\end{array}$ & $\begin{array}{l}-4.3 \\
579\end{array}$ & $\begin{array}{l}1.37 \\
227\end{array}$ & $\begin{array}{l}55.40 \\
62.52\end{array}$ & $\begin{array}{l}0.75 \\
0.75\end{array}$ & $\begin{array}{l}0.66 \\
0.66\end{array}$ & $\begin{array}{l}-1.8 E+02 \\
-1.7 E+02\end{array}$ & $\begin{array}{l}7.3 \mathrm{E}+01 \\
1 . \mathrm{E}+03\end{array}$ & $\begin{array}{l}-1.3 E+01 \\
-1.5 E+01\end{array}$ & $\begin{array}{l}-7.1 E+01 \\
-8.5 E+01\end{array}$ & $\begin{array}{l}-1.7 \mathrm{E}+02 \\
7.4 \mathrm{E}+03\end{array}$ & $\begin{array}{l}-3.60 \mathrm{E}+02 \\
815 \mathrm{E}+03\end{array}$ \\
\hline Supermarket & Los Angeles & New & heat & 35.3 & 0.63 & 0.69 & $\begin{array}{l}1.0 \\
0\end{array}$ & 0 & 0 & 0 & 0 & 2.27 & $\begin{array}{l}156.77 \\
156.77\end{array}$ & 0.75 & $\begin{array}{l}0.60 \\
0.66\end{array}$ & $0.0 \mathrm{E}+00$ & $0.0 \mathrm{E}+00$ & $0.0 \mathrm{E}+00$ & $0.0 \mathrm{E}+00$ & $0.0 \mathrm{E}+00$ & $0.00 E+00$ \\
\hline Supermarket & Los Angeles & New & cool & 37.7 & 0.63 & 0.69 & 13.6 & -3.4 & -1.6 & 64.5 & 73.1 & 1.82 & 183.58 & 0.75 & 0.66 & $-1.4 \mathrm{E}+03$ & $4.4 \mathrm{E}+03$ & $-8.0 \mathrm{E}+01$ & $-4.5 E+02$ & $2.2 \mathrm{E}+04$ & $2.40 \mathrm{E}+04$ \\
\hline & & New & heat & 30.2 & 0.63 & 0.69 & 0 & -0.1 & -0.1 & 0 & -0.2 & 7.69 & 76.05 & 0.75 & 0.66 & $-7.0 \mathrm{E}+01$ & $0.0 \mathrm{E}+00$ & $-8.8 E+00$ & $-5.0 \mathrm{E}+01$ & $0.0 \mathrm{E}+00$ & $-1.29 \mathrm{E}+02$ \\
\hline Supermarket & Houston & New & cool & 26.2 & 0.63 & 0.69 & 10.8 & -1.3 & -0.9 & 73.6 & 82.2 & 2.17 & 87.64 & 0.75 & 0.66 & $-3.0 \mathrm{E}+02$ & $2.0 \mathrm{E}+03$ & $-2.6 \mathrm{E}+01$ & $-1.5 \mathrm{E}+02$ & $1.4 \mathrm{E}+04$ & $1.55 \mathrm{E}+04$ \\
\hline Supermarket & Minneapolis & Old & heat & 62.4 & 0.66 & 0.71 & 3.5 & -7 & -3.3 & -18.3 & -25.1 & 1.96 & 28.11 & 0.75 & 0.66 & $-4.4 \mathrm{E}+02$ & $1.8 \mathrm{E}+02$ & $-2.7 \mathrm{E}$ & $-1.5 E+02$ & $-1.0 E+03$ & $-1.45 E+03$ \\
\hline Supermarket & Minneapolis & Old & cool & 63.9 & 0.66 & 0.71 & 6.7 & -1.1 & -0.7 & 35.2 & 40.1 & 2.27 & 26.47 & 0.75 & 0.66 & $-7.5 \mathrm{E}+01$ & $3.7 \mathrm{E}+02$ & $-6.3 \mathrm{E}+00$ & $-3.6 \mathrm{E}+01$ & $2.1 \mathrm{E}+03$ & $2.37 \mathrm{E}+03$ \\
\hline Supermarket & Chicago & Old & heat & 104.3 & 0.66 & 0.71 & 2.8 & -5 & -2.4 & -9.9 & -14.5 & 1.79 & 132.64 & 0.75 & 0.66 & $-1.3 E+03$ & $6.1 \mathrm{E}+02$ & $-8.5 E+01$ & $-4.8 \mathrm{E}+02$ & $-2.3 E+03$ & $-3.64 E+03$ \\
\hline Supermarket & Chicago & Old & cool & 94 & 0.66 & 0.71 & 7.3 & -1.2 & -0.7 & 41.8 & 47.2 & 2.33 & 122.75 & 0.75 & 0.66 & $-3.9 \mathrm{E}+02$ & $1.9 \mathrm{E}+03$ & $-3.0 E+01$ & $-1.7 \mathrm{E}+02$ & $1.2 \mathrm{E}+04$ & $1.33 E+04$ \\
\hline & Washington & Old & heat & 100.8 & 0.66 & 0.71 & 1.4 & -2.6 & -1.3 & -3.7 & -6.2 & 1.39 & 65.72 & 0.75 & 0.66 & $-2.7 E+02$ & $1.2 \mathrm{E}+02$ & $-1.8 \mathrm{E}+01$ & $-1.0 \mathrm{E}+02$ & $-3.4 \mathrm{E}+02$ & $-6.07 E+02$ \\
\hline Supermarket & Washington & Old & cool & 89.2 & 0.66 & 0.71 & 7.9 & -1 & -0.8 & 51 & 57.1 & 2.33 & 51.34 & 0.75 & 0.66 & $-1.4 \mathrm{E}+02$ & $8.7 \mathrm{E}+02$ & $-1.4 E+01$ & $-8.1 \mathrm{E}+01$ & $6.1 \mathrm{E}+03$ & $6.73 E+03$ \\
\hline Supermarket & Los Angeles & Old & heat & 85.3 & 0.66 & 0.71 & & & & 0 & 0 & & 53.87 & 0.75 & 0.66 & $0.0 E+00$ & $0.0 E+00$ & $0.0 E+00$ & $0.0 E+00$ & $0.0 E+00$ & $0.00 E+00$ \\
\hline Supermarket & Los Angeles & Old & cool & 86.8 & 0.66 & 0.71 & 13.8 & -3.3 & -1.3 & 62.9 & 72.1 & 1.89 & 52.10 & 0.75 & 0.66 & $-3.7 E+02$ & $1.3 \mathrm{E}+03$ & $-1.9 \mathrm{E}+01$ & $-1.1 \mathrm{E}+02$ & $6.2 \mathrm{E}+03$ & $6.94 \mathrm{E}+03$ \\
\hline Supermarket & Houston & Old & heat & 134.1 & 0.66 & 0.71 & 0.1 & -0.2 & -0.1 & -0.2 & -0.4 & 4.35 & 44.61 & 0.75 & 0.66 & $-4.4 E+01$ & $1.8 \mathrm{E}+01$ & $-2.9 \mathrm{E}+00$ & $-1.6 \mathrm{E}+01$ & $-3.9 E+01$ & $-8.42 E+01$ \\
\hline Supermarket & Houston & Old & cool & 119.6 & 0.66 & 0.71 & 11 & -1.1 & -0.8 & 73.4 & 82.5 & 2.22 & 70.92 & 0.75 & 0.66 & $-2.0 \mathrm{E}+02$ & $1.6 \mathrm{E}+03$ & $-1.9 \mathrm{E}+01$ & $-1.1 \mathrm{E}+02$ & $1.2 E+04$ & $1.28 \mathrm{E}+04$ \\
\hline Warehouse & Minneapolis & New & heat & 168.3 & 0.58 & 0.70 & 0.8 & -0.8 & -1 & -11.6 & -12.6 & 1.56 & 276.99 & 0.75 & 0.66 & $-4.4 E+02$ & $3.3 \mathrm{E}+02$ & $-6.5 \mathrm{E}+01$ & $-3.7 \mathrm{E}+02$ & $-5.0 E+03$ & $-5.57 E+03$ \\
\hline & Minneapolis & New & cool & & & 0.70 & 0.2 & 0 & 0 & 0.7 & 0.9 & 1.59 & 76.00 & 0.7 & 0.66 & $0.0 \mathrm{E}+00$ & $2.3 \mathrm{E}+01$ & $0.0 \mathrm{E}+00$ & 0.0 & $8.4 \mathrm{E}+01$ & $1.07 \mathrm{E}+02$ \\
\hline Warehouse & Chicago & New & heat & 329.6 & 0.58 & 0.70 & 0.7 & -0.6 & -0.8 & -7.8 & -8.5 & 1.56 & 734.76 & 0.75 & 0.66 & $\begin{array}{l}-8.8 \mathrm{E}+02 \\
-1\end{array}$ & $7.6 \mathrm{E}+02$ & $-1.4 \mathrm{E}+02$ & $-7.8 \mathrm{E}+02$ & $-9.0 \mathrm{E}+03$ & $-9.99 E+03$ \\
\hline War & Chica & New & cool & 90.4 & 0.58 & 0.70 & 0.4 & 0 & 0 & 1.1 & 1.5 & 1.35 & 183.73 & 0.7 & 0.66 & $0.0 E$ & 9.4 & 0.0 & & 2.7 & $3.67 E+02$ \\
\hline Warehouse & Washin & New & . & 69 & 9 & & 0.6 & -0.5 & -0.6 & -4.7 & -5.2 & 1.79 & 36 & & 0.66 & -7. & & & & & \\
\hline Wa & Washing & New & cool & 277 & 0.59 & 0.70 & 0.6 & 0 & 0 & 2.2 & 2.8 & 1.54 & 54 & 0.7 & 0.66 & $0.0 \mathrm{E}+00$ & & & & & \\
\hline Wa & is & New & heat & 588.2 & 0 & 0.71 & 0.3 & -0.2 & -0.2 & -1 & -1.1 & 2.27 & 339.26 & 0. & & & & & & $-7.7>0>0$ & -9.0 \\
\hline Warehouse & Los Angeles & New & cool & 193.2 & 0.60 & 0.71 & 0.8 & 0 & 0 & 2.7 & 3.5 & 1.75 & 265.43 & 0.7 & 0.66 & $0.0 \mathrm{E}+00$ & $3.4 \mathrm{E}>\mathrm{C}$ & $0.0 E+00$ & $0.0 E+00$ & $1.3 \mathrm{E}-\mathrm{C}$ & 1. $60 \mathrm{E}+03$ \\
\hline Warehouse & Houston & New & heat & 306.8 & 0.60 & 0.71 & 0.4 & -0.2 & -0.3 & -1.8 & -1.9 & 1.92 & 273.63 & 0.7 & 0.66 & $-1.3 \mathrm{E}+02$ & $1.9 \mathrm{E}+02$ & $-2.4 \mathrm{E}+01$ & $-1.3 \mathrm{E}+02$ & $-9.5 \mathrm{E}+02$ & $-1.04 E+03$ \\
\hline Warehouse & Houston & New & cool & 232.1 & 0.60 & 0.71 & 0.5 & 0.1 & 0 & 1.5 & 2.1 & 2.13 & 267.12 & 0.75 & 0.66 & $7.1 E+01$ & $2.6 \mathrm{E}+02$ & $0.0 E+00$ & $0.0 E+00$ & $8.5 E+02$ & $1.19 E+03$ \\
\hline Wareho & Minnear & Old & he & 769.3 & 72 & 0.72 & 1.6 & -1.8 & -1 & -12.3 & -13.5 & 1.59 & 234.69 & 0.75 & 0.66 & & 5.4 & 01 & & & \\
\hline & Minne & Old & & & & 0.72 & 0.6 & 0 & 0 & 0.8 & 1. & 1.89 & 58 & 0. & & & & & & & \\
\hline Wa & & Old & heat & 246 & 2 & 0.7 & 1. & -1.4 & -0.8 & -8.3 & -9.2 & 1.61 & 710 & 0. & 0. & & 1.4 & -1.4 & & -9.5 & 04 \\
\hline & & Old & & 4 & & 0.7 & 0 & 0 & 0 & 1.2 & 2. & 1.69 & 11 & 0. & & $0 . c$ & & 0.0 & & & \\
\hline$w_{z}$ & w & Old & ne & 148 & & 0. & 1.1 & -1 & -0.6 & -5.1 & -5.6 & 1.79 & & 0. & 0. & & & & & & $-5.58 \mathrm{E}+03$ \\
\hline Wo & w & $\mathrm{Ol}$ & & 54 & & & 1. & 0 & 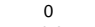 & 2.2 & 4 & 1.89 & & 0. & & & & & & & 03 \\
\hline w & Los An & Old & he & 77 & 2 & 0.74 & 0.5 & -0.3 & -0.2 & -1.2 & -1.2 & 2.04 & 373.64 & 0.75 & 0.66 & $-2.4 \mathrm{E}$ & $3.4 \mathrm{E}+02$ & $-2.3 E+01$ & $-1.3 \mathrm{E}+02$ & -9.21 & $-9.66 \mathrm{E}+02$ \\
\hline Warehouse & Los Angeles & $\begin{array}{l}\text { Old } \\
\text { Old }\end{array}$ & $\begin{array}{c}\text { cool } \\
\text { heat }\end{array}$ & 377.7 & 0.72 & 0.74 & 1.8 & -0.1 & 0 & 3.1 & 4.8 & 2.17 & 219.17 & 0.75 & 0.66 & $-5.0 \mathrm{E}+01$ & $\begin{array}{l}7.7 \mathrm{E}+02 \\
3\end{array}$ & $0.0 E+00$ & $0.0 \mathrm{E}+00$ & $1.5 \mathrm{E}+03$ & $2.19 \mathrm{E}+03$ \\
\hline $\begin{array}{l}\text { Warehouse } \\
\text { Warehouse }\end{array}$ & $\begin{array}{l}\text { Houston } \\
\text { Houston }\end{array}$ & $\begin{array}{l}\text { Old } \\
\text { Old }\end{array}$ & $\begin{array}{l}\text { heat } \\
\text { cool }\end{array}$ & $\begin{array}{l}6966.8 \\
547.7\end{array}$ & $\begin{array}{l}0.72 \\
0.72\end{array}$ & $\begin{array}{l}0.74 \\
0.74\end{array}$ & $\begin{array}{l}0.7 \\
1.4\end{array}$ & $\begin{array}{l}-0.4 \\
0.2\end{array}$ & $\begin{array}{c}-0.2 \\
0.1\end{array}$ & $\begin{array}{l}-2.1 \\
1.7\end{array}$ & $\begin{array}{l}-2 \\
3.4\end{array}$ & $\begin{array}{l}1.96 \\
2.27\end{array}$ & $\begin{array}{l}243.04 \\
182.35\end{array}$ & $\begin{array}{l}0.75 \\
0.75\end{array}$ & $\begin{array}{l}0.66 \\
0.66\end{array}$ & $\begin{array}{l}-2.20+0202 \\
8.6 \mathrm{E}+01\end{array}$ & $\begin{array}{l}3.0 \mathrm{E}+02 \\
5.2 \mathrm{E}+02\end{array}$ & $\begin{array}{l}-1.4 \mathrm{E}+01 \\
6.2 \mathrm{E}+00\end{array}$ & $\begin{array}{l}-8.1 E+01 \\
3.5 E+01\end{array}$ & $\begin{array}{l}-1.0 E+03 \\
7.0 E+02\end{array}$ & $\begin{array}{l}-9.97 E+02 \\
1.35 E+03\end{array}$ \\
\hline & & & & & & & & & & & & & 760.12 & & & -4.17 & & -2.68 & & & \\
\hline Supermarket & To & To & cool & 635.1 & & & & & & & & & 788.58 & & & $-3.41 E+03$ & $1.54 \mathrm{E}+04$ & $-2.42 E+02$ & $-1.37 E+03$ & $9.24 E+04$ & $1.03 E+05$ \\
\hline $\begin{array}{l}\text { Warehouse } \\
\text { Warehouse }\end{array}$ & $\begin{array}{l}\text { Total } \\
\text { Total }\end{array}$ & $\begin{array}{l}\text { Total } \\
\text { Total }\end{array}$ & $\begin{array}{l}\text { heat } \\
\text { cool }\end{array}$ & $\begin{array}{r}8270 \\
3057.5\end{array}$ & & & & & & & & & 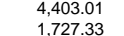 & & & $\begin{array}{l}-6.23 \mathrm{E}+03 \\
1.08 \mathrm{E}+02\end{array}$ & $\begin{array}{l}5.68 \mathrm{E}+03 \\
2.75+03\end{array}$ & $\begin{array}{l}-6.76 \mathrm{E}+02 \\
6.22+00\end{array}$ & $\begin{array}{l}-3.83 E+03 \\
3.52 E+01\end{array}$ & $\begin{array}{l}-4.23 E+04 \\
6.32 E+03\end{array}$ & $\begin{array}{c}-4.74 \mathrm{~F}+04 \\
9.22 \mathrm{E}+03\end{array}$ \\
\hline & & & & & & & & & & & & & $1,727.33$ & & & $1.08 \mathrm{E}+02$ & & $6.22 \mathrm{E}+00$ & 3.52E+01 & $6.32 E+03$ & $9.22 E+03$ \\
\hline
\end{tabular}

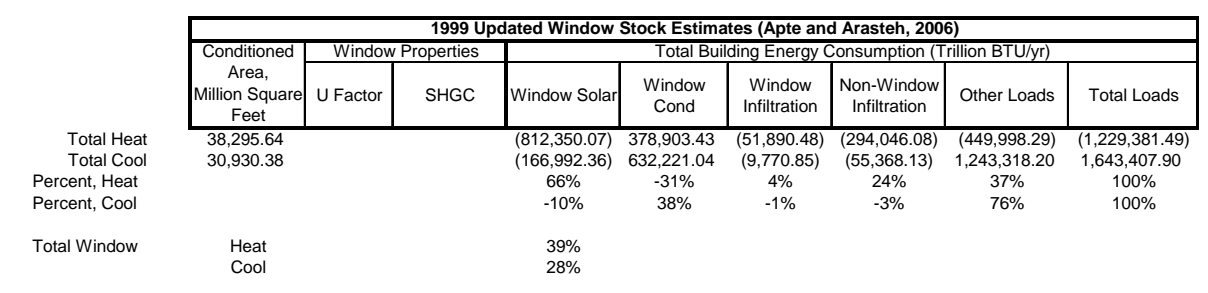




\section{Bibliography}

ASHRAE (2005). ASHRAE Handbook - Fundamentals, American Society of Heating, Refrigerating and Air-Conditioning Engineers.

Carmody, J., Selkowitz, S., et al. (2000). Residential Windows: A Guide to New Technologies and Energy Performance. New York, W.W. Norton and Company.

Ducker Research Company (2004). Study of the U.S. Market for Windows, Doors and Skylights. Bloomfield Hills, MI

EIA. (2001). "Residential Energy Consumption Survey." 2006, from http://www.eia.doe.gov/emeu/recs/contents.html.

Finlayson, E., Arasteh, D., et al. (1993). Window 4.0: Documentation of Calculation Procedures, Lawrence Berkeley Laboratory: LBL-33943 http://windows.lbl.gov/software/window/41/WINDOW\%204.0\%20Documentatio n\%20of\%20Calculation\%20Procedures.pdf

Huang, J. and Franconi, E. (1999). Commercial Heating and Cooling Loads Component Load Analysis. Berkeley, CA, Building Technologies Department, Lawrence Berkeley National Laboratory: LBNL-37208

Huang, J., Hanford, J., et al. (1999). Residential Heating and Cooling Loads Component Analysis. Berkeley, CA, Building Technologies Department, Lawrence Berkeley National Laboratory: LBNL-44636

Ritschard, R. L., Hanford, J. W., et al. (1992). Single-Family Heating and Cooling Requirements: Assumptions, Methods and Summary Results. Berkeley, CA, Lawrence Berkeley National Laboratory: LBL-30377

Sage Electrochromics. (2006). "Press release, February 10, 2006, announcing first production shipment of electrochromic windows." from http://www.sage-ec.com.

US DOE Energy Information Administration. (1999). "1999 Commercial Building Energy Consumption Survey." from http://www.eia.doe.gov/emeu/cbecs/contents.html.

US DOE Office of Energy Efficiency and Renewable Energy (2005). 2005 Buildings Energy Databook, US Department of Energy, Office of Energy Efficiency and Renewable Energy.: http://btscoredatabook.eren.doe.gov/ 